CHARACTERISTICS OF U.S. GEOLOGICAL SURVEY

DISCHARGE MEASUREMENTS FOR WATER YEAR 1990

U.S. GEOLOGICAL SURVEY

Open-File Report 92-493

Stennis Space Center, Mississippi 


\section{U.S. DEPARTMENT OF THE INTERIOR}

MANUEL LUJAN, JR., Secretary

\section{U.S. GEOLOGICAL SURVEY}

Dallas L. Peck, Director

For additional information write to:

Office of Surface Water

Water Resources Division

U.S. Geological Survey

Stennis Space Center, MS 39529
Copies of this report can be purchased from:

U.S. Geological Survey

Books and Open-File Reports Section

Federal Center, Box 25425

Denver, Colorado 80225 


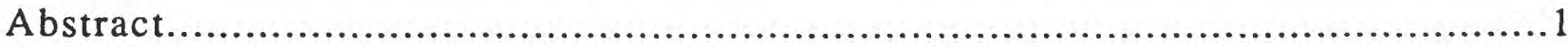

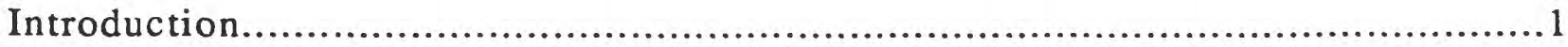

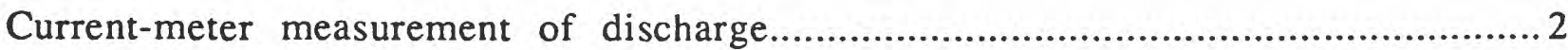

Survey of meter usage

Current meters used by the U.S. Geological Survey................................................5

Rating of discharge measurements by U.S. Geological Survey personnel.....................7

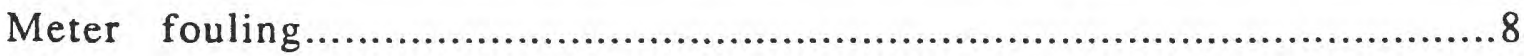

Measurement characteristics that contribute to error............................................

Characteristics of discharge measurements for water year 1990..................................... 10

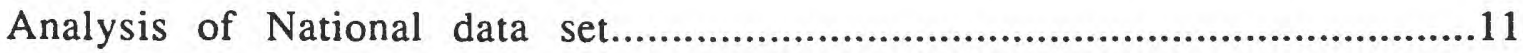

Measurement type............................................................... 11

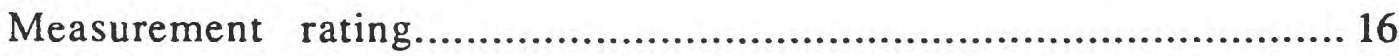

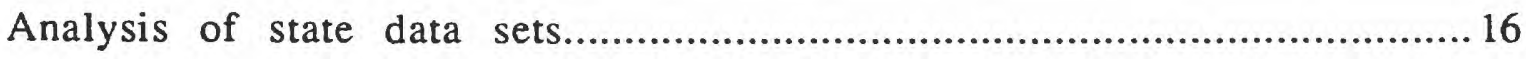

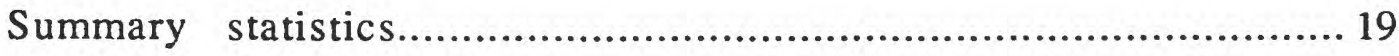

Frequency analysis of velocity, depth, rating type and measurement type.......... 23

Computed flow characteristics.............................................................. 73

Comparison of questionnaire results with computer data-base......................................... 77

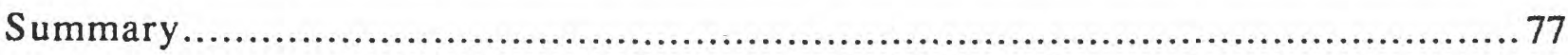

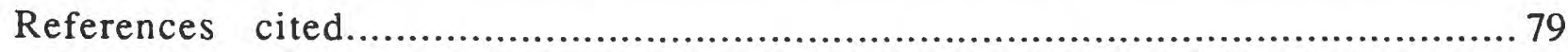




\section{FIGURES}

Figure 1. Current-meter questionnaire sent to District offices of the U.S. Geological Survey..... 3

2. Photographs of current meters listed on the questionnaire except for acoustic meter.... 6

3-57. Charts:

3. Frequency of use of various meter types in percent, weighted by the number of measurements

4. Frequency distributions of mean velocity and mean depth for all discharge

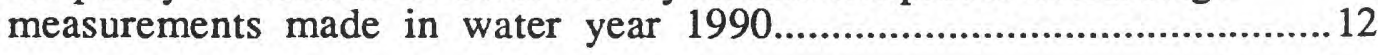

5. Percentage of water year 1990 measurements by measurement type............... 13

6. Frequency distributions of velocity plotted for wading, bridge, cableway and ice measurement types........................................................... 15

7. Percentage of water year 1990 measurements by measurement rating...............16

8. Frequency distributions of velocity for excellent, good, fair, and poor measurement rating................................................................ 18

9. Alaska's velocity and depth frequency distributions and percentage of measurements by measurement rating for water year 1990 .

10. Alabama's velocity and depth frequency distributions and percentage of measurements by measurement rating and by measurement type for water year 1990

11. Arkansas's velocity and depth frequency distributions and percentage of measurements by measurement rating and by measurement type for water year 1990

12. Arizona's velocity and depth frequency distributions and percentage of measurements by measurement rating and by measurement type for water year 1990

13 California's velocity and depth frequency distributions and percentage of measurements by measurement rating and by measurement type for water year 1990

14. Connecticut's velocity and depth frequency distributions and percentage of measurements by measurement rating and by measurement type for water year 1990.

15. Colorado's velocity and depth frequency distributions and percentage of measurements by measurement rating and by measurement type for water year 1990 .

16. Delaware's velocity and depth frequency distributions and percentage of measurements by measurement rating and by measurement type for water year 1990 
17. Florida's velocity and depth frequency distributions and percentage of measurements by measurement rating and by measurement type for water year 1990.

18. Georgia's velocity and depth frequency distributions and percentage of measurements by measurement rating and by measurement type

for water year 1990

19. Hawaii's velocity and depth frequency distributions and percentage of measurements by measurement rating and by measurement type for water year 1990

20. Iowa's velocity and depth frequency distributions and percentage of measurements by measurement rating and by measurement type for water year 1990.

21. Idaho's velocity and depth frequency distributions and percentage of measurements by measurement rating and by measurement type for water year 1990

22. Illinois's velocity and depth frequency distributions and percentage of measurements by measurement rating and by measurement type

for water year 1990

23. Indiana's velocity and depth frequency distributions and percentage of measurements by measurement rating and by measurement type for water year 1990

24. Kansas's velocity and depth frequency distributions and percentage of measurements by measurement rating and by measurement type for water year 1990

25. Kentucky's velocity and depth frequency distributions and percentage of measurements by measurement rating and by measurement type for water year 1990

26. Louisiana's velocity and depth frequency distributions and percentage of measurements by measurement rating and by measurement type for water year 1990

27. Massachusetts's and Rhode Island's velocity and depth frequency distributions and percentage of measurements by measurement rating and by measurement type for water year 1990

28. Maryland's velocity and depth frequency distributions and percentage of measurements by measurement rating and by measurement type for water year 1990

29. Maine's velocity and depth frequency distributions and percentage of measurements by measurement rating for water year 1990

30. Michigan's velocity and depth frequency distributions and percentage of measurements by measurement rating and by measurement type for water year 1990. 
31. Minnesota's velocity and depth frequency distributions and percentage of measurements by measurement rating and by measurement type for water year 1990

32. Missouri's velocity and depth frequency distributions and percentage of measurements by measurement rating and by measurement type for water year 1990

33. Mississippi's velocity and depth frequency distributions and percentage of measurements by measurement rating and by measurement type for water year 1990

34. Montana's velocity and depth frequency distributions and percentage of measurements by measurement rating and by measurement type for water year 1990

35. North Carolina's velocity and depth frequency distributions and percentage of measurements by measurement rating and by measurement type for water year 1990.

36. North Dakota's velocity and depth frequency distributions and percentage of measurements by measurement rating and by measurement type for water year 1990.

37. Nebraska's velocity and depth frequency distributions and percentage of measurements by measurement rating and by measurement type for water year 1990.

38. New Jersey's velocity and depth frequency distributions and percentage of measurements by measurement rating and by measurement type for water year 1990.

39. New Mexico's velocity and depth frequency distributions and percentage of measurements by measurement rating and by measurement type for water year 1990.

40. Nevada's velocity and depth frequency distributions and percentage of measurements by measurement rating and by measurement type for water year 1990.

41. New York's velocity and depth frequency distributions and percentage of measurements by measurement rating and by measurement type for water year 1990

42. Ohio's velocity and depth frequency distributions and percentage of measurements by measurement rating for water year 1990

43. Oklahoma's velocity and depth frequency distributions and percentage of measurements by measurement rating and by measurement type for water year 1990. 
44. Oregon's velocity and depth frequency distributions and percentage of measurements by measurement rating and by measurement type for water year 1990 .

45. Pennsylvania's velocity and depth frequency distributions and percentage of measurements by measurement rating and by measurement type for water year 1990.

46. Puerto Rico's velocity and depth frequency distributions and percentage of measurements by measurement rating and by measurement type for water year 1990.

47. South Carolina's velocity and depth frequency distributions and percentage of measurements by measurement rating and by measurement type for water year 1990.

48. South Dakota's velocity and depth frequency distributions and percentage of measurements by measurement rating and by measurement type for water year 1990.

49. Tennessee's velocity and depth frequency distributions and percentage of measurements by measurement rating and by measurement type for water year 1990 .

50. Texas's velocity and depth frequency distributions and percentage of measurements by measurement rating and by measurement type for water year 1990.

51. Utah's velocity and depth frequency distributions and percentage of measurements by measurement rating and by measurement type for water year 1990.

52. Vermont's and New Hampshire's velocity and depth frequency distributions and percentage of measurements by measurement rating and by measurement type for water year 1990.

53. Virginia's velocity and depth frequency distributions and percentage of measurements by measurement rating for water year 1990

54. Washington's velocity and depth frequency distributions and percentage of measurements by measurement rating and by measurement type for water year 1990 .

55. Wisconsin velocity and depth frequency distributions and percentage of measurements by measurement rating and by measurement type for water year 1990 .

56. West Virginia velocity and depth frequency distributions and percentage of measurements by measurement rating and by measurement type

for water year 1990 .

57. Wyoming velocity and depth frequency distributions and percentage of measurements by measurement rating and by measurement type for water year 1990 . 


\section{TABLES}

Table 1. Number of replies to questionnaire by state

2. Frequency of use by U.S. Geological Survey personnel of various types of current meters

3. Percent of discharge measurement types rated excellent, good, fair, or poor............. 8

4. Percent time that type-AA and pygmy meters are fouled by various agents.............. 8

5. Frequency with which adverse measurement conditions cause discharge measurements to be rated poor or fair.

6. Frequency of occurrence of measurement conditions that may adversely affect measurement accuracy.

7. Summary statistics for discharge measurements made in water year 1990.

8a.-e. Summary statistics for:

a. Wading discharge measurements made in water year 1990

(Alaska, Maine, Ohio, and Virginia not available)

b. Bridge discharge measurements made in water year 1990

(Alaska, Maine, Ohio, and Virginia not available).

c. Cableway discharge measurements made in water year 1990

(Alaska, Maine, Ohio, and Virginia not available).

d. Ice discharge measurements made in water year 1990

(Alaska, Maine, Ohio, and Virginia not available).

e. Boat discharge measurements made in year 1990

(Alaska, Maine, Ohio, and Virginia not available).

9a.-d. Summary statistics for discharge measurements rated:

a. Excellent made in water year 1990

b. Good made in water year 1990 (Ohio cases rated good/fair are not included).

c. Fair made in water year 1990 (Ohio cases rated good/fair are not included).

d. Poor made in water year 1990.

10. Number of discharge measurement sites and average measurements per site listed by state.

11. Summary statistics by state for width, area, mean velocity, discharge, and mean depth for water year 1990

12. Summary statistics for computed flow characteristics for measurements made in water year 1990. 
13. Summary statistics for computed flow characteristics listed by state

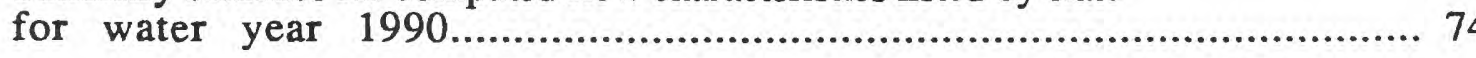




\section{CONVERSION FACTORS}

Multiply

feet ( $\mathrm{ft}$ )

miles (mi)

cubic feet per second $\left(\mathrm{ft}^{3} 3 / \mathrm{s}\right)$
By To obtain

0.3048 meters (m)

1.609 kilometers $(\mathrm{km})$

0.02832 cubic meters per second $\left(\mathrm{m}^{3} / \mathrm{s}\right)$ 


\title{
CHARACTERISTICS OF U.S. GEOLOGICAL SURVEY DISCHARGE MEASUREMENTS FOR WATER YEAR 1990
}

by Janice M. Fulford

\begin{abstract}
The U.S. Geological Survey (USGS) Water Resources Division (WRD) makes tens of thousands of stream discharge measurements each year throughout the United States and Puerto Rico. Most of the measurements require the use of point velocity instrumentation. A survey of current-meter usage and discharge-measurement data for water year 1990 was undertaken to help evaluate the performance of existing instrumentation. The velocity, discharge, and depth ranges measured; the types of meters used; and the measurement problems encountered were surveyed. Survey respondents indicated vegetation as the most frequent cause of significant measurement error. Information from the survey quantifies the range of several common flow characteristics and measurement conditions for streams throughout the United States.
\end{abstract}

\section{INTRODUCTION}

Tens of thousands of discharge measurements are made by personnel of the U.S. Geological Survey (USGS) each year. These discharge measurements of a river or open channel flow are made with a variety of techniques that may or may not require the use of point-velocity instruments. However, the majority of discharge measurements made by the USGS use pointvelocity instruments (current meters) to determine the discharge. The accuracy and performance of these current meters have a major effect on the quality of the discharge measurements made by the USGS.

The development of new instrumentation technology such as the acoustic and electromagnetic current meters, and renewed interest in the performance of older instrumentation prompted the creation of a committee by the USGS in 1990 to investigate current meters. As part of the initial investigations the committee performed two tasks: a review of literature from previous meter studies and a survey of the characteristics of discharge measurements made by the USGS. This paper presents the results of the second task--the characteristics of discharge measurements as determined from the survey of water year 1990 (October 1, 1989 to September 30, 1990) discharge measurements.

The survey was undertaken to determine the characteristics of discharge measurements made by the USGS: the velocity, discharge, and depth ranges measured; the types of meters used; and the measurement problems encountered. This knowledge will be used in evaluations of the performance characteristics of current meters used by the USGS.

The survey for water year 1990 has two parts: a questionnaire and a computer data-base retrieval. The questionnaire has questions on which meters were used, on the conditions under which meters were used, and on the quantity and quality of discharge measurements. The computer data-base retrievals contain information summarizing each discharge measurement made in the 1990 water year.

The paper is divided into a short summary of current-meter measurement of discharge and two major sections (1) survey of meter usage and (2) discharge measurements. The first major section contains the results and discussion of the questionnaire. The second section contains the compilation and discussion of the computer data-base retrieval. 


\section{CURRENT-METER MEASUREMENT OF DISCHARGE}

Because the survey data is either discharge-measurement data or related to discharge measurements, a general knowledge of discharge measurement techniques and terminology is helpful in understanding the data and data analysis. Discharge is measured with a current meter by measuring velocity in various locations across a stream and multiplying the velocity by the product of the contributing depth and width of the stream.

The USGS uses the midsection method to determine discharge. A cross section that spans the stream width is divided into several vertical strips. Velocity is measured in each strip at either 0.6 of the depth or 0.2 and 0.8 of the depth depending on the depth of flow. The discharge in each strip is determined by multiplying the area of the strip by its mean velocity, either the 0.6 measurement or the average of the 0.2 and the 0.8 measurements. The discharges for all strips are summed to yield the total discharge.

Discharge measurements are classified into measurement types by the technique used to cross the stream, such as wading, boat, bridge, cableway, or ice. The measurement type used depends on the depth of flow, velocity, and the location of the measurement section.

Rantz (1982) gives a detailed description of streamgaging techniques used by the USGS in "Measurement and Computation of Streamflow: Volume 1. Measurement of Stage and Discharge." Descriptions of streamgaging techniques can also be found in Herschy (1985).

\section{SURVEY OF METER USAGE}

The questionnaire surveyed USGS data-section personnel on their current-meter use during water year 1990. Data section chiefs in District offices of the USGS were asked to respond to the questionnaire and (or) to have personnel of their choosing respond. Districts were asked to return at least one completed questionnaire. (A "District" is usually a state, except for a few districts that have more than one state.) The questionnaire is one page and requires either an estimated percentage or a count for answers. Figure 1 is a copy of the distributed questionnaire.

Ninety-two completed questionnaires were returned. Questionnaires were received from all Districts except two. Many Districts sent multiple responses. California sent the most (10) and 30 Districts sent the minimum requested (one each). Table 1 lists the number of questionnaires returned by state and the responses to the first four questions on the questionnaire. States in the same District are listed together except for Delaware and Maryland. Delaware and Maryland are listed separately because a separate response was received from each. The total number of continuous-record sites (sites at which stage is continuously recorded) reported on the questionnaire is 6,098 . The average number of measurements made per continuous-record site as reported on the questionnaire is 8.7. The total number of partial-record sites (measurement sites at which stage is not continuously recorded) reported on the questionnaire is 2,872 .

Because each questionnaire does not represent the same number of discharge measurements, averages of the responses were computed unweighted and weighted for questions 5 through 14 (see figure 1). The unweighted average is the sum of the responses for a question divided by the number of questionnaires, 92 . It is indicative of what the responding field personnel experience and may not be a good estimate of the average 1990 water year measurement. It is an estimate of a typical District's response to a question. 
Questionnaire for field personnel for water year ' 90

District:_ Name:___ Phone:

1. How many continuous record sw sites did you serve from your office

2. For an average site, number of discharge measurements made in WY ' 90

3. How many other discharge measurement sites do you serve from your office

4. For an average site, number of discharge measurements made in WY 190

5.For wading measurements, what percentage are made with: Price___ Pygmy __

6.For wading measurements, what percentage are rated:

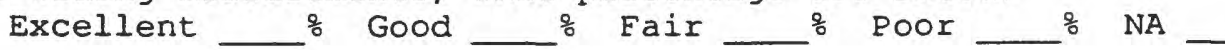

7. For cable-way measurements, what percentage are rated:

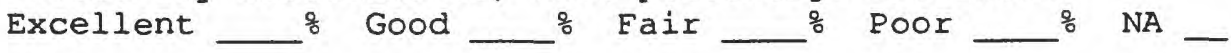

8.For bridge measurements, what percentage are rated:

Excellent _— Good __ $\frac{\circ}{\circ}$ Fair _— Poor _— ${ }^{\circ}$ NA

9.For boat measurements, what percentage are rated:

Excellent __ Good __ ${ }^{\circ}$ Fair ___ Poor ___ ${ }^{\circ}$ NA

10. For ice measurements, what percentage are rated:

Excellent \% Good Fair \% Poor \% NA

For the following questions(11-14), show estimated percentages for use of meters of the measurement conditions. Note, the sum of percentages for any question may exceed 100 percent.

11. how often your office uses the following meters in discharge measurements, - Price pygmy electromagnetic acoustic

12. how often your field personnel have fouling of Price and pygmy meters from, aquatic vegetation _ice/slush _ silt/sediment _ misc. debris

13. how often your discharge measurements are rated fair or poor because of,

- vegetation

- high turbulence

- surface waves

- sand bed channel

- low velocities air line/wet line

- submerged debris

- floating debris

- ice problems shallow depths rapid stage changes

- high sediment load

- extreme horizontal angles

- irregular cross-sections

- other (specify)

14. how often your discharge measurements are made in sections with; velocities <.2fps depths <1.5 ft large eddies boils, whitewater beds of boulders _beds of cobbles _beds of gravel _ice cover or slush

15. Please enter any additional comments on field use of meters.

Figure 1.--Current-meter use questionnaire sent to District offices of the U.S. Geological Survey. 
Table 1.--Number of responses to questionnaire, number of continuous-record sites, number of partial-record sites and number of measurements per site by state

\begin{tabular}{|c|c|c|c|c|c|}
\hline \multirow{2}{*}{ STATE } & \multirow{2}{*}{$\begin{array}{l}\text { Number } \\
\text { of } \\
\text { responses }\end{array}$} & \multicolumn{2}{|c|}{ Continuous-record sites } & \multicolumn{2}{|c|}{ Partial-record sites } \\
\hline & & $\begin{array}{l}\text { Number } \\
\text { of sites }\end{array}$ & $\begin{array}{l}\text { Measurements } \\
\text { per site }\end{array}$ & $\begin{array}{c}\text { Number } \\
\text { of sites }\end{array}$ & $\begin{array}{l}\text { Measurements } \\
\text { per site }\end{array}$ \\
\hline Alabama & 1 & 92 & 9.0 & 30 & 0.0 \\
\hline Alaska & 1 & 80 & 6.0 & 65 & 2.0 \\
\hline Arkansas & 1 & 51 & 8.0 & 255 & 1.0 \\
\hline Arizona & 3 & 122 & 8.0 & 10 & 1.6 \\
\hline California & 10 & 445 & 10.4 & 224 & 4.8 \\
\hline Colorado & 5 & 269 & 12.2 & 50 & 2.0 \\
\hline Connecticut & 1 & 42 & 7.0 & 20 & 6.0 \\
\hline Delaware & 1 & 22 & 10.0 & 46 & 3.0 \\
\hline Florida & 3 & 276 & 7.0 & 106 & 4.0 \\
\hline Georgia & 1 & 128 & 9.0 & 141 & 1.0 \\
\hline Hawaii & 1 & 105 & 7.0 & 160 & 2.0 \\
\hline Iowa & 3 & 122 & 12.0 & 51 & 1.2 \\
\hline Idaho & 1 & 202 & 9.0 & 74 & 5.0 \\
\hline Illinois & 3 & 144 & 9.5 & 38 & 1.5 \\
\hline Indiana & 1 & 176 & 8.0 & 0 & .0 \\
\hline Kentucky & 1 & 110 & 9.0 & 23 & 2.0 \\
\hline Louisiana & 1 & 61 & 8.0 & 30 & 2.0 \\
\hline $\begin{array}{l}\text { Massachusetts \& } \\
\text { Rhode Island }\end{array}$ & 1 & 85 & 6.0 & 70 & 3.0 \\
\hline Maine & 1 & 48 & 4.0 & 0 & .0 \\
\hline Maryland & 1 & 67 & 9.0 & 0 & .0 \\
\hline Mississippi & 1 & 80 & 10.0 & 30 & 8.0 \\
\hline Minnesota & 3 & 83 & 9.0 & 62 & .1 .7 \\
\hline Missouri & 3 & 122 & 10.0 & 33 & .7 \\
\hline Montana & 1 & 210 & 10.0 & 180 & 2.0 \\
\hline North Carolina & 4 & 169 & 7.5 & 78 & 3.8 \\
\hline North Dakota & 1 & 73 & 12.0 & 29 & 10.0 \\
\hline Nebraska & 1 & 143 & 13.0 & 6 & 2.0 \\
\hline New Hampshire \& Vermont & 1 & 63 & 8.0 & 20 & 3.0 \\
\hline New Jersey & 1 & 92 & 9.0 & 150 & 2.0 \\
\hline New Mexico & 3 & 149 & 10.7 & 31 & 5.3 \\
\hline Nevada & 1 & 120 & 8.0 & 135 & 3.0 \\
\hline New York & 2 & 97 & 7.5 & 110 & 2.5 \\
\hline Ohio & 1 & 132 & 6.0 & 4 & 3.0 \\
\hline Oklahoma & 1 & 113 & 9.0 & 60 & 2.0 \\
\hline Oregon & 2 & 180 & 6.0 & 8 & 1.0 \\
\hline Pennsylvania & 2 & 177 & 9.5 & 155 & 3.0 \\
\hline South Carolina & 1 & 119 & 8.0 & 4 & 6.0 \\
\hline South Dakota & 3 & 147 & 10.6 & 22 & 3.0 \\
\hline Tennessee & 3 & 82 & 8.7 & 102 & .3 \\
\hline Texas & 5 & 274 & 7.6 & 53 & 3.6 \\
\hline Utah & 1 & 157 & 10.0 & 6 & 4.0 \\
\hline Virginia & 3 & 84 & 7.0 & 59 & 1.0 \\
\hline Washington & 3 & 210 & 6.7 & 55 & 5.0 \\
\hline Wisconsin & 1 & 112 & 8.0 & 29 & 6.0 \\
\hline West Virginia & 1 & 77 & 6.0 & 8 & 2.0 \\
\hline Wyoming & 1 & 125 & 10.0 & 50 & 4.0 \\
\hline
\end{tabular}


The weighted average is the average adjusted or weighted by the number of discharge measurements (the number of continuous-record sites times the number of measurements per site plus the number of partial sites times the number of measurements per partial site) that each response represents. The weighted average is computed by summing the products of the individual responses with its respective number of measurements and dividing it by the total number of measurements. It is an estimate of the response that would have been given for a typical discharge measurement for the United States or the average that would have been computed from questionnaires answered for each 1990 discharge measurement.

Differences between the unweighted and weighted average result if the typical District response is different than the response for the typical discharge measurement. The numbers presented for each question are the weighted average except where differences between the weighted and unweighted averages are significant. In those cases both averages are presented (and noted as to whether they are the weighted or unweighted average). Numbers not noted in the report text are weighted averages of the responses. Because the numbers given by the respondents are estimates, the unweighted and weighted averages of the responses for a given question may not sum to 100 percent.

For questions 12 through 14, the percentages of non-zero responses are listed. This percentage is an estimate of the significance of the average or averages. An average response with a large percent of non-zero values is more significant than a similar average with a smaller percent of non-zero values.

\section{Current Meters used by the U.S. Geological Survey}

The.USGS primarily uses two current meters, the Price type-AA and the Price pygmy. Both of these meters are mechanical, vertical-axis meters that use six conical cups that rotate about the meter shaft to translate the horizontal flow velocity into rotational velocity. Revolutions of the meter are signaled by a switching mechanism, either optical or cat whisker, and are counted by an electronic counter (current meter digitizer) or by an operator listening with a headset for the sound generated by each switch closure. The type-AA meter is the larger meter, with a 5-inch-diameter rotor that is 2 inches high. The pygmy is two-fifths as large as the type-AA.

In addition to these two meters, ice, electromagnetic, Ott-type ${ }^{1}$, and acoustic meters are occasionally used. The electromagnetic and acoustic meters are not standardized and differ by manufacturer. The Ott-type meter referred to in this report is a USGS designed meter that uses a special Ott designed component propeller on a horizontal-axis meter for moving-boat

measurements. Ice meters are various meters used for discharge measurements under ice and are usually a type-AA, pygmy, or Canadian-type yoke meter. Occasionally a vane meter is used for under-ice measurements. In figure 2 are photographs of the various meters listed on the questionnaire.

All questionnaire respondents use both the type-AA and pygmy current meters. For wading measurements (question 5), the type-AA is used for more measurements than the pygmy, 54 percent and 46 percent, respectively. For all types of measurements, the type-AA meter is the most commonly used, about 60 percent of the time. The pygmy is used about 39 percent of the time. However, 35 percent of the respondents indicated that they used the pygmy more frequently than the type-AA. Nine percent of the respondents indicated equal use of the type-AA and pygmy.

\footnotetext{
${ }^{1}$ Use of brand names in this report is for identification purposes only and does not constitute endorsement by the U.S. Geological Survey.
} 


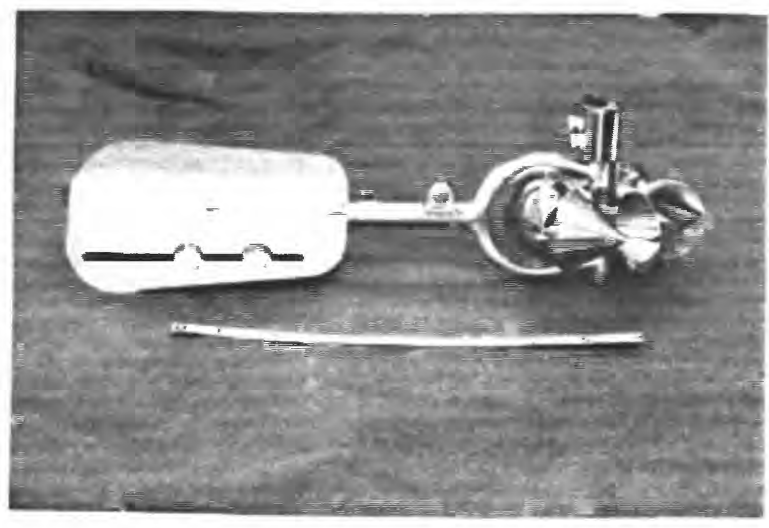

Price type -AA meter

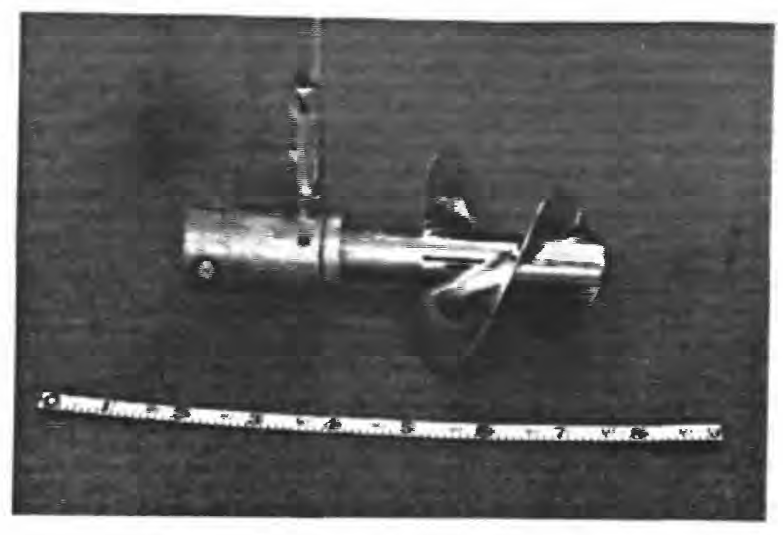

Ott-type moving boat meter

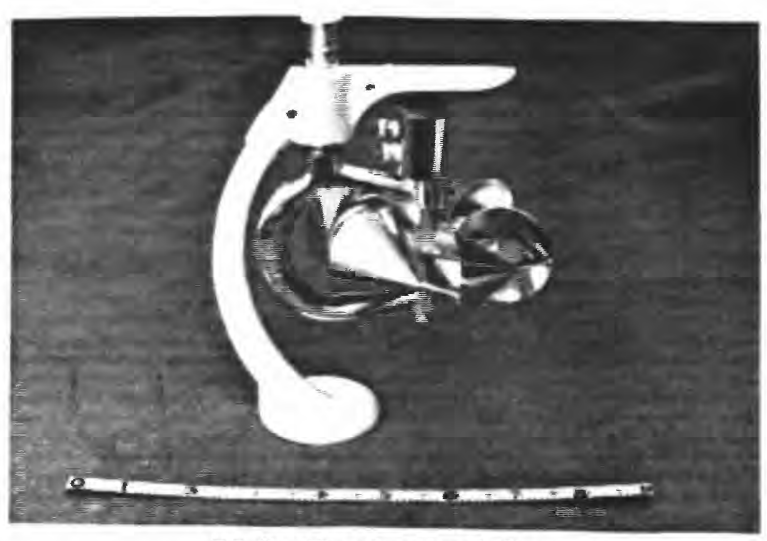

U.S. Geological Survey winter yoke meter

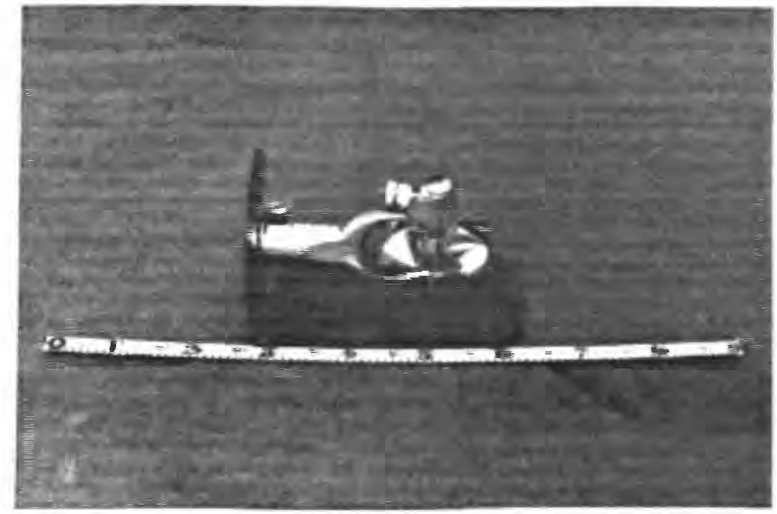

Price pygmy meter

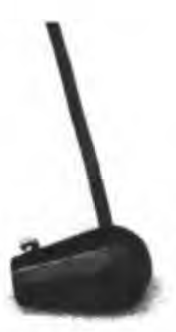

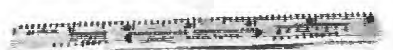

example of electromagnetic meter (Marsh McBirney)

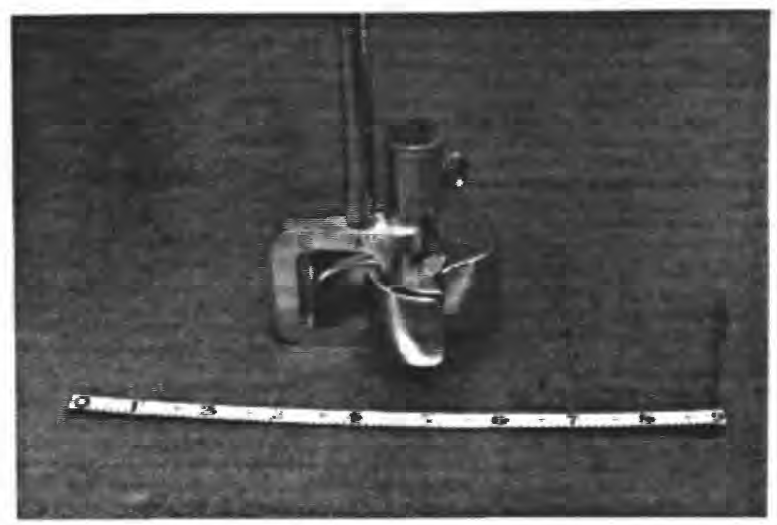

vane winter meter

Figure 2.-- Current meters listed on questionnaire except for acoustic meter. (Tape in pictures is 0.9 feet long. Ruler in electromagnetic meter photo is 0.5 feet long.) 
Table 2. Frequency of use by U.S. Geological Survey personnel of various types of current meters

\begin{tabular}{lcc}
\hline Meter type & Percent using & $\begin{array}{c}\text { Percent of time used } \\
\text { (weighted average) }\end{array}$ \\
\hline Price type-AA & 100.0 & 60.1 \\
Price Pygmy & 100.0 & 39.2 \\
Electro-magnetic & 7.6 & .2 \\
Acoustic & 6.5 & .1 \\
Ott-type & 3.3 & .1 \\
Ice & 13.0 & 2.2 \\
\hline
\end{tabular}

Most respondents did not indicate use of the other current meters listed on the questionnaire. For respondents who use meters other than the type-AA and pygmy, they used an ice meter 9 percent of the time and electromagnetic-, acoustic-, and Ott-type meters 2 to 3 percent of the time. The frequency of use of various current meters by USGS personnel is listed in table 2 and is shown in figure 3.

\section{Rating of Discharge Measurements by U.S. Geological Survey Personnel}

Discharge measurements are rated by USGS personnel as to their accuracy or total error (the difference between the measured and actual discharge). They are rated as either excellent, good, fair, or poor. For each measurement rating the error ranges in percent are: less than or equal to 2 percent, excellent; more than 2 and less than 5 percent, good; greater than or equal to 5 and less than 8 percent, fair, and equal to or more than 8 percent, poor.

Characteristics of the measurement section (the number of verticals at which the velocity is measured; the degree of turbulence; the steadiness of the stage; and the presence of ice, vegetation, or wind) affect the accuracy of discharge measurements and, consequently, the rating given to a particular discharge measurement. This rating is subjective and may not reflect the true accuracy of the discharge measurement.

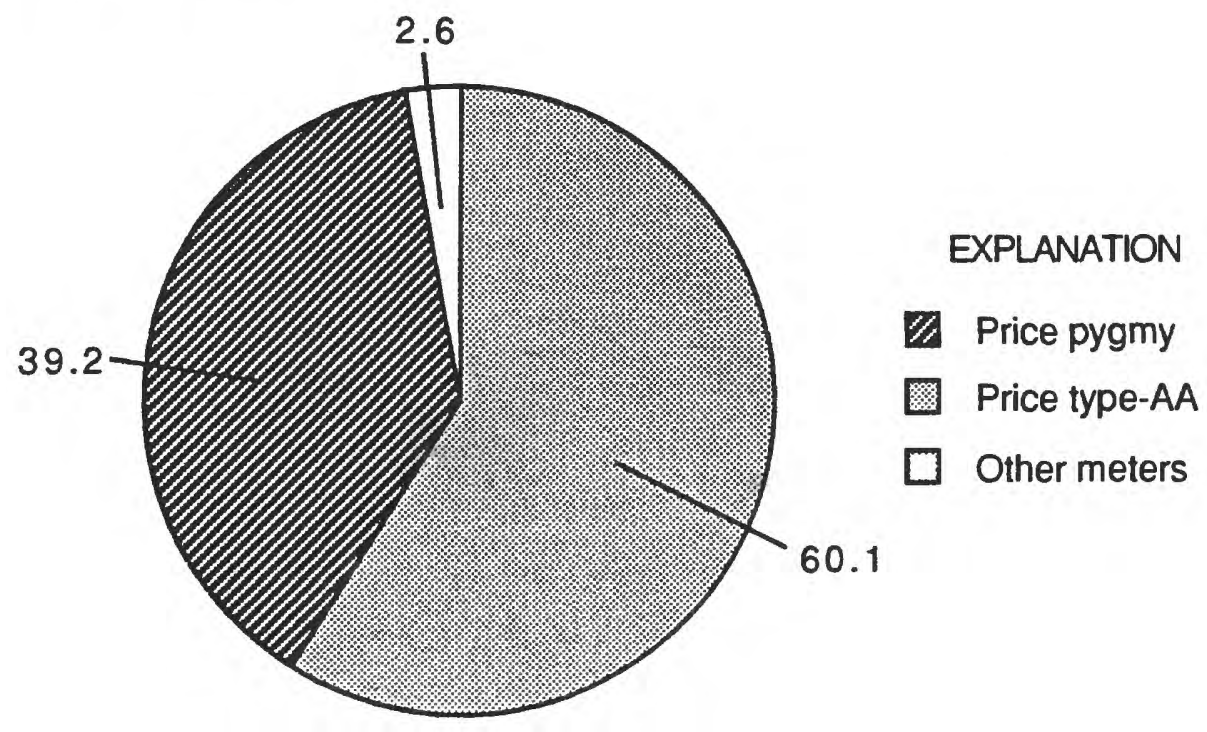

Figure 3.--Frequency of use of various meter types in percent. 
Table 3.--Percentage of wading, cableway, bridge, boat, and ice measurements rated excellent, good, fair, or poor by respondents performing measurement type and percentage of respondents that performed each measurement type,

\begin{tabular}{lcccrc}
\hline Rating & Wading & Cableway & Bridge & Boat & Ice \\
\hline Excellent & 1.0 & 1.3 & .4 & .2 & .8 \\
Good & 61.0 & 71.4 & 58.6 & 87.2 & 13.4 \\
Fair & 28.9 & 26.9 & 31.8 & 24.4 & 39.7 \\
Poor & 8.9 & 4.7 & 7.9 & 5.8 & 47.9 \\
Performed & 100.0 & 75.0 & 95.7 & 44.6 & 47.8 \\
\hline
\end{tabular}

A summary of the responses to the questions on measurement rating (questions 6 to 10) is listed in table 3. Included in the table are the percentage of respondents that performed each measurement type. Other percentages shown in table 3 are the weighted averages of the responses from those personnel that indicated performance of the measurement type.

All respondents performed wading measurements. Bridge measurements were performed by about 96 percent and cableway measurements by 75 percent of the respondents. Boat and ice measurements were each performed by less than half.

Measurement personnel rated the majority of discharge measurements as good. The next most common ratings were fair and poor. Few measurements are rated excellent. Ice measurements were usually rated poor or fair with about 13 percent of ice measurements rated good and less than a percent rated excellent. Boat and cableway measurements have slightly better average ratings than do wading and bridge measurements.

\section{Meter Fouling}

All current meters are subject to fouling. In particular, mechanical meters, such as the type$\mathrm{AA}$ and the pygmy, are sensitive to fouling by debris and other agents. For type-AA and pygmy meters, respondents indicated that aquatic vegetation is the primary source of meter fouling. Miscellaneous debris was the next most likely source of fouling, followed by ice/slush and silt/sediments. Table 4 summarizes the responses to the question on type-AA and pygmy-meter fouling and the percentage of non-zero responses.

\section{Measurement Characteristics that Contribute to Enror}

There are many measurement section characteristics or conditions that result in fair or poor discharge measurement ratings. An ideal measurement section is a straight reach with a stable smooth streambed that is free of eddies and converging or diverging currents. Turbulence, rapidly varying flow (spatially and/or temporally), and debris are examples of measurement section conditions that cause significant errors in discharge measurements. Normally stream gagers avoid sections with these conditions, but sections with poor measurement conditions are sometimes used

\begin{tabular}{lcc} 
Table 4.--Percent time that type-AA and pygmy meters are fouled by various agents \\
\hline Fouling agent & $\begin{array}{c}\text { Percentage of time fouled } \\
\text { (weighted average) }\end{array}$ & $\begin{array}{c}\text { Percentage of non-zero } \\
\text { responses }\end{array}$ \\
\hline Aquatic vegetation & 12.4 & 92.4 \\
Ice/slush & 4.9 & 48.9 \\
Silt/sediment & 2.5 & 28.3 \\
Miscellaneous debris & 9.2 & 73.9 \\
\hline
\end{tabular}


Table 5.--Frequency with which adverse measurement conditions cause discharge measurements to be rated poor or fair

\begin{tabular}{lccc}
\hline Adverse condition & $\begin{array}{c}\text { Frequency of } \\
\text { occurrence } \\
\text { (average) }\end{array}$ & $\begin{array}{c}\text { Frequency of } \\
\text { occurrence } \\
\text { (weighted average) }\end{array}$ & $\begin{array}{c}\text { Percent of } \\
\text { non-zero } \\
\text { responses }\end{array}$ \\
\hline Vegetation & 13.6 & 15.3 & 92.4 \\
Low velocities & 9.7 & 10.5 & 82.6 \\
Rapid stage changes & 8.6 & 8.0 & 85.9 \\
Shallow depths & 10.9 & 13.6 & 77.2 \\
Irregular cross-sections & 12.0 & 13.8 & 70.7 \\
High turbulence & 7.2 & 7.5 & 75.0 \\
Floating debris & 5.4 & 4.8 & 67.4 \\
Sand-bed channels & 9.3 & 6.1 & 48.9 \\
Ice problems & 5.7 & 7.1 & 51.1 \\
Submerged debris & 4.1 & 3.5 & 55.4 \\
Extreme horizontal angles & 2.9 & 2.7 & 56.5 \\
Surface waves & 3.4 & 3.0 & 48.9 \\
Air line/wet line & 1.5 & 1.3 & 31.5 \\
High sediment load & 1.5 & 1.4 & 14.1 \\
\hline
\end{tabular}

out of necessity. Respondents answered two questions that pertained to measurement-section conditions, one on how conditions adversely affect measurement ratings and one on how frequently less than ideal measurement conditions are encountered.

A summary of the responses to the questions concerning causes of poor or fair measurement ratings is presented in table 5 . Both the weighted and unweighted averages are presented in the table because of the noticeable differences between them. Based on the percent frequency of occurrence and the percent of non-zero responses, respondents most of ten indicated vegetation as causing measurements to be rated fair or poor. Also conditions ranking high as causing fair or poor ratings are irregular cross-sections, low velocities, rapid-stage changes, and shallow depths.

A few noticeable differences between the unweighted average and weighted average for sand-bed channels, ice problems, shallow depths, vegetation, and irregular cross sections exist. For sand-bed channels, the weighted average is smaller ( 6.1 percent) than the average (9.3 percent) and in contrast to the average, is less important than high turbulence, rapid-stage changes, and ice problems as a cause of fair or poor measurement rating. This may be because sand-bed channels do not occur in every District, but are a significant cause of fair or poor ratings where they occur. The weighted average for ice problems (7.1) is larger than the average (5.7) and in contrast to the average values, ice problems are more significant than sand-bed channels as a cause of fair or poor ratings. This may be because fewer questionnaires were returned by Districts that have icy weather. Shallow depths, vegetation, and irregular cross sections have weighted averages larger than the average. However, this difference does not significantly change their ranking relative to the other causes of fair or poor measurement rating.

Respondents also indicated how frequently they measured in sections with various conditions that may adversely affect the accuracy of discharge measurements. The frequency with which measurements are made in these less than ideal conditions is presented in table 6. Based on the percent frequency of occurrence and the percent of non-zero responses, depths of less than 1.5 $\mathrm{ft}$, cobbled streambeds, and gravel streambeds are the most frequently encountered of these 


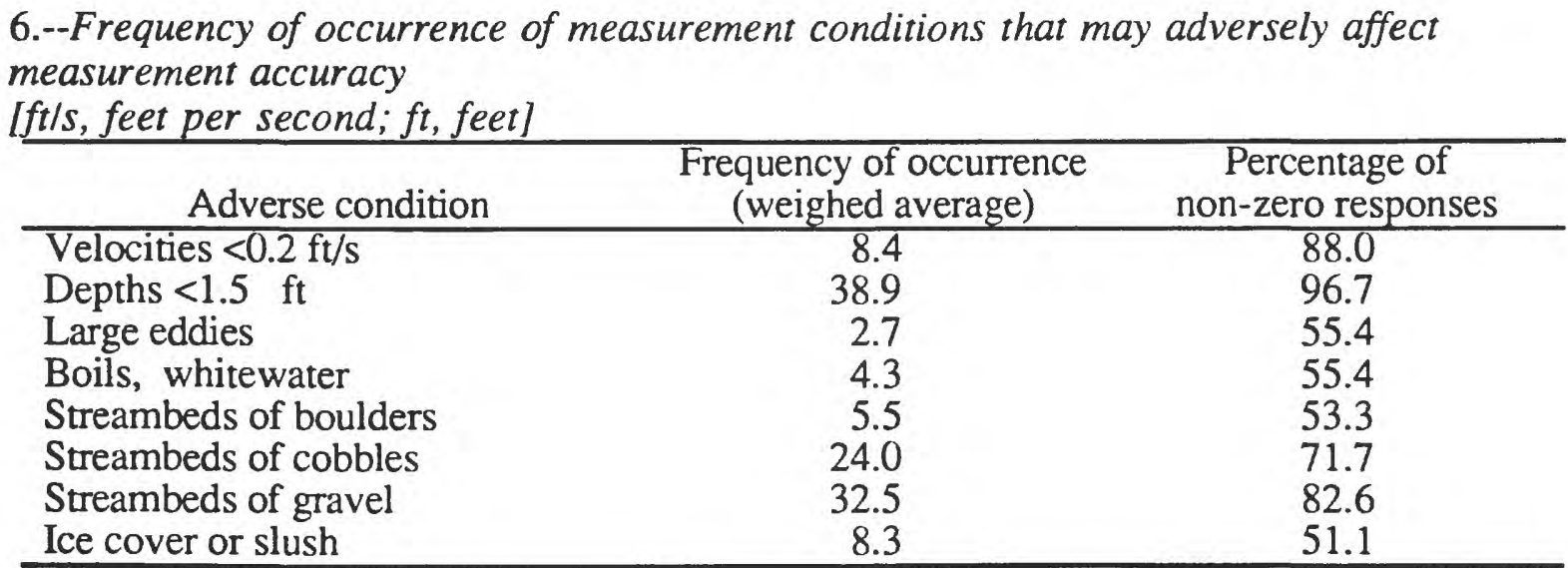

conditions. About one quarter of all discharge measurements are made in sections affected by one of these conditions. The other conditions listed on the questionnaire are experienced less than 9 percent of the time.

\section{CHARACTERISTICS OF DISCHARGE MEASUREMENTS FOR WATER YEAR 1990}

Discharge-measurement data for water year 1990 were retrieved from each USGS district. Districts having discharge measurements stored in computer files retrieved and sent an Automated Data Processing System (ADAPS) computer file through the USGS computer network. Four Districts (Alaska, Maine, Ohio, and Virginia) that did not have discharge data stored in computer files, sent photocopies of forms (USGS form 9-207) containing discharge-measurement data for water year 1990 for their continuous-record gaging sites. The photocopied data from those Districts were manually entered into computer files and included in the analysis.

Unfortunately, some data available from the computer retrievals are not available on the photocopied forms. The computer retrievals contain data for mean velocity, discharge, width, area, measurement type, and measurement rating. The photocopied forms do not have data for measurement type and the computer retrievals have missing data for some measurements.

All data were checked for errors. The files for the photocopied data were carefully checked for typographical errors and preliminary data analyses for all files were checked for suspicious results.

Preliminary processing of the retrieved ADAPS files revealed unexpected problems with the retrievals and data. Because of these problems, each state's ADAPS computer files were processed and verified by a computer program. The program checked for and removed repeated station retrievals, retrievals of stations with no 1990 measurements, and data outside the 1990 water year. Additionally, the program removed ADAPS header text and checked for unusual depths (very small, very large) and other differences between discharge and the product of mean velocity and area that were greater than 10 percent.

These suspicious measurement data were flagged by the program, examined individually for errors, and corrected. Obvious typographical errors in data, such as transposed numbers and misplaced decimal points, were corrected. Data that had inconsistencies other than obvious typographical errors were deleted. Most computer files received contained errors, the most common being the retrieval of data outside the desired water year. The verified, processed computer files and the manually entered measurement files were then analyzed. 
A statistical analysis computer program was used to analyze the resulting files. The discharge data were analyzed for each District (or state) separately and for the combined data. Additionally, several common flow characteristics (squared Froude number, wetted perimeter, and conveyance times roughness) were computed from the data and analyzed.

The data analysis is presented here in three sections: analysis of the entire (National) data set, analysis by state (or WRD District), and analysis of computed flow parameters. Summary statistics for mean velocity, width, area, discharge, measurement rating, measurement type, and mean depth are presented in the first two sections. Summary statistics for the computed flow characteristics are presented in the third section by state (or WRD District) and for the combined data. Parts of data associated with some discharge measurements are missing or inconsistent and consequently not included in the computation of summary statistics. As a result of these omissions, the number or count of each data type summarized are different.

\section{Analysis of National Data Set}

The combined District files of discharge measurements for water year 1990 contain data from 6,199 continuous-record sites and 53,799 measurements. The average number of discharge measurements per site is 8.7 with a standard deviation of 2.3 measurements. These measurements include a small fraction of discharge measurements made by flumes or estimated, but the overwhelming majority of the measurements are made with current meters. Table 7 lists the summary statistics for discharge, mean velocity, width, mean flow depth, and area. The count of discharges in table 7 does not equal the total number of discharge measurements because of missing and deleted measurement data. Negative discharges in table 7 are from tidally affected sites that have reverse flows.

Because this survey was motivated by interest in current-meter performance, depth and velocity were analyzed more extensively than were the other data types. Frequency distributions for mean velocity and mean flow depth are shown in figure 4 . For most discharge measurements mean velocities are less than $2.0 \mathrm{ft} / \mathrm{s}$. Almost half of the discharge measurements are made in mean flow depths of less than $1.25 \mathrm{ft}$. Using the mean values, the average 1990 discharge measurement has a discharge of $1,960 \mathrm{ft}^{3} / \mathrm{s}$, and a mean velocity of $1.52 \mathrm{ft} / \mathrm{s}$.

\section{Measurement Type}

The combined data were grouped by measurement type and analyzed. Illustrated in figure 5 is the percentage of measurements attributed to each measurement type: bridge, wading, cableway, ice, and boat. For the combined data that had measurement type entered, approximately three quarters are wading measurements. Bridge measurements are the second most common type, making up nearly 16 percent of the measurements.

Table 7.--Summary statistics for discharge measurements made in water year 1990 [ft, feet; $f_{t}{ }^{2}$, square feet; ft $/ s$, feet per second; $f_{t}{ }^{3} / s$, cubic feet per second]

\begin{tabular}{lccccc}
\multicolumn{1}{c}{ Characteristic } & Mean & $\begin{array}{c}\text { Standard } \\
\text { deviation }\end{array}$ & Low & High & Count \\
\hline Width $(\mathrm{ft})$ & 105.4 & 234 & 0.1 & 13,675 & 51,543 \\
Area $\left(\mathrm{ft}^{2}\right)$ & 663.2 & 3,328 & 0 & 149,000 & 51,117 \\
Velocity $(\mathrm{ft} / \mathrm{s})$ & 1.52 & 1.09 & 0 & 12.66 & 51,076 \\
Discharge $(\mathrm{ft} / \mathrm{s})$ & 1,960 & 13,557 & -836 & 679,800 & 53,188 \\
Depth $(\mathrm{ft})$ & 2.3 & 3.4 & 0 & 51.5 & 51,069 \\
\hline
\end{tabular}



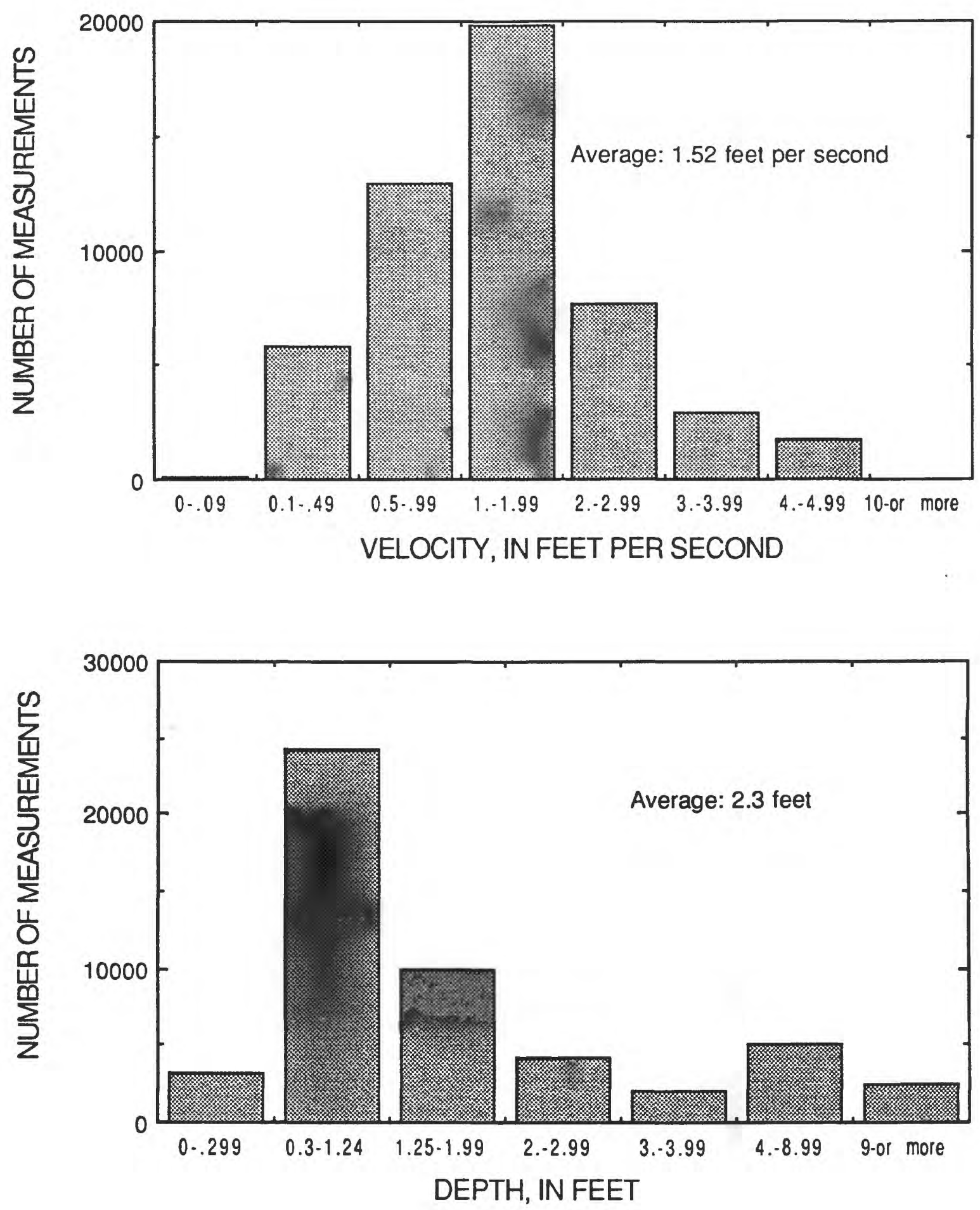

Figure 4.--Frequency distributions of mean velocity and mean flow depths for all discharge measurements made in water year 1990. 


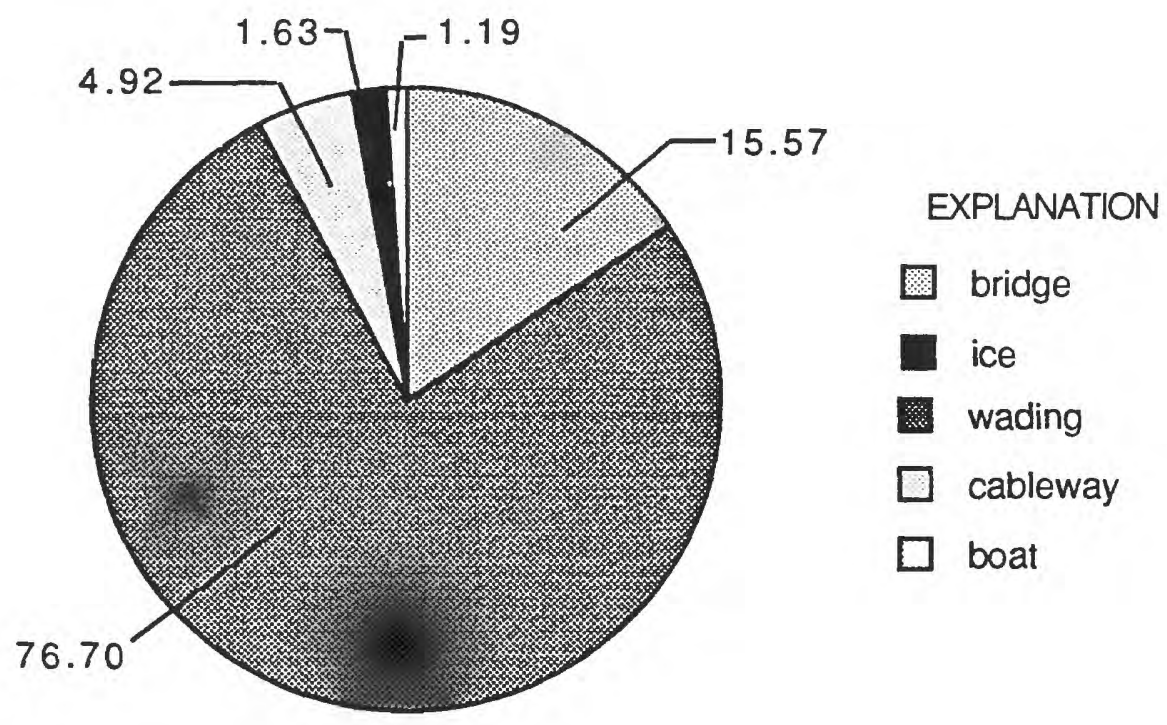

Figure 5.--Percentage of water year 1990 measurements by measurement type.

Summary statistics for measurement data with measurement type available are shown grouped by measurement type in tables $8 \mathrm{a}$ through $8 \mathrm{e}$. Measurement type data were not available for Maine, Virginia, Ohio, or Alaska.

The lowest mean velocities are for ice measurements and the highest mean velocities are for cableway measurements. Average discharges are highest for bridge measurements and lowest for wading measurements. Boat measurements have the largest average area and wading measurements have the smallest area. Wading and ice measurements have the smallest average flow depth and bridge measurements have the largest.

Velocity frequency distributions plotted for the four most frequently used measurement types, wading, bridge, cableway, and ice, are shown in figure 6. The distribution for wading measurements is very similar in shape to the velocity distribution for all measurements (figure 4) because wading measurements make up about three quarters of all measurements. The velocity frequency distribution shape for ice measurements looks similar to the distribution for wading measurements except for the lower mean velocity. Velocity frequency distributions for bridge and cableway measurements are skewed to the higher velocities, because high velocity discharges and large depths cannot be waded.

Table 8a.--Summary statistics for wading discharge measurements made in water year 1990 (data for Alaska, Maine, Ohio, and Virginia not available) $\left[f t\right.$, feet; $f_{t}{ }^{2}$, square feet; $f t / s$, feet per second; $f_{t}{ }^{3} / s$, cubic feet per second $]$

\begin{tabular}{lcclcc}
\hline Characteristic & Mean & $\begin{array}{c}\text { Standard } \\
\text { deviation }\end{array}$ & Low & High & Count \\
\hline Width $(\mathrm{ft})$ & 50.5 & 78.9 & 0.15 & 8,209 & 36,962 \\
Area $\left(\mathrm{ft}^{2}\right)$ & 68.4 & 234.9 & 0 & 25,400 & 36,708 \\
Velocity $(\mathrm{ft} / \mathrm{s})$ & 1.23 & 0.73 & 0 & 12.66 & 36,690 \\
Discharge $(\mathrm{ft} 3 / \mathrm{s})$ & 108 & 642 & -0.79 & 87,900 & 37,050 \\
Depth $(\mathrm{ft})$ & 1.0 & 0.7 & 0 & 21.0 & 36,683 \\
\hline
\end{tabular}


Table 8b.--Summary statistics for bridge discharge measurements made in water year 1990 (data for Alaska, Maine, Ohio, and Virginia not available)

[ft, feet; $f_{t}{ }^{2}$, square feet; $f t / s$, feet per second; ft $3 /$ s, cubic feet per second]

\begin{tabular}{lccccc}
\hline Characteristic & Mean & $\begin{array}{c}\text { Standard } \\
\text { deviation }\end{array}$ & Low & High & Count \\
\hline Width $(\mathrm{ft})$ & 299.3 & 427.7 & 1.7 & 9,540 & 7,479 \\
Area $\left(\mathrm{ft}^{2}\right)$ & 2,703 & 5,707 & 1.8 & 100,000 & 7,389 \\
Velocity $(\mathrm{ft} / \mathrm{s})$ & 2.38 & 1.41 & 0.02 & 10.31 & 7,375 \\
Discharge $\left(\mathrm{ft}^{3} / \mathrm{s}\right)$ & 8,515 & 25,290 & -836 & 660,000 & 7,487 \\
Depth $(\mathrm{ft})$ & 6.7 & 4.6 & 0.14 & 51.5 & 7,381 \\
\hline
\end{tabular}

Table 8c.--Summary statistics for cableway discharge measurement made in water year 1990 (data for Alaska, Maine, Ohio, and Virginia not available)

[ft, feet; $f_{t}{ }^{2}$, square feet; $f t / s$, feet per second; $f t 3 / s$, cubic feet per second]

\begin{tabular}{|c|c|c|c|c|c|}
\hline Characteristic & Mean & $\begin{array}{l}\text { Standard } \\
\text { deviation }\end{array}$ & Low & High & Count \\
\hline Width $(\mathrm{ft})$ & 214.2 & 235.8 & 16 & 2,768 & 2,770 \\
\hline Area $\left(\mathrm{ft}^{2}\right)$ & 1,871 & 5,969 & 34.1 & 98,800 & 2,760 \\
\hline Velocity $(\mathrm{ft} / \mathrm{s})$ & 3.01 & 1.54 & 0.24 & 10.04 & 2,758 \\
\hline Discharge $\left(\mathrm{ft}^{3} / \mathrm{s}\right)$ & 6,755 & 28,887 & 17.9 & 631,000 & 2,805 \\
\hline Depth (ft) & 5.4 & 5.2 & 0.29 & 45.0 & 2,758 \\
\hline
\end{tabular}

Table 8d.--Summary statistics for ice discharge measurements made in water year 1990 (data for Alaska, Maine, Ohio, and Virginia not available)

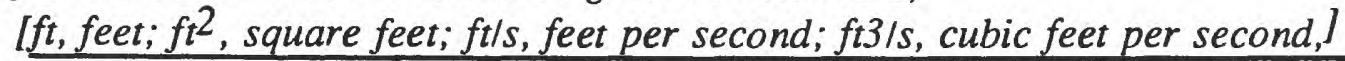

\begin{tabular}{lcclcc}
\hline Characteristic & Mean & $\begin{array}{c}\text { Standard } \\
\text { deviation }\end{array}$ & Low & High & Count \\
\hline Width $(\mathrm{ft})$ & 82.1 & 120.7 & 0.7 & 1,415 & 776 \\
Area $\left(\mathrm{ft}^{2}\right)$ & 124 & 270 & 0.1 & 2,650 & 763 \\
Velocity $(\mathrm{ft} / \mathrm{s})$ & 0.92 & 0.50 & 0.01 & 2.97 & 760 \\
Discharge $\left(\mathrm{ft}^{3} / \mathrm{s}\right)$ & 143 & 393 & 0 & 4,820 & 779 \\
Depth $(\mathrm{ft})$ & 1.0 & 0.8 & 0.04 & 6.5 & 763 \\
\hline
\end{tabular}

Table 8e.--Summary statistics for boat discharge measurements made in water year 1990 (data for Alaska, Maine, Ohio, and Virginia not available)

[ft, feet; $f_{t}{ }^{2}$, square feet; $f t / s$, feet per second; $f_{t}{ }^{3} / s$, cubic feet per second]

\begin{tabular}{lccccc}
\hline Characteristic & Mean & $\begin{array}{c}\text { Standard } \\
\text { deviation }\end{array}$ & Low & High & Count \\
\hline Width $(\mathrm{ft})$ & 468.3 & 844.9 & 36.8 & 13,675 & 572 \\
Area $\left(\mathrm{ft}^{2}\right)$ & 6,932 & 15,160 & 115 & 149,000 & 567 \\
Velocity $(\mathrm{ft} / \mathrm{s})$ & 1.74 & 1.03 & 0.14 & 4.94 & 566 \\
Discharge $\left(\mathrm{ft}^{3} / \mathrm{s}\right)$ & 15,593 & 41,144 & -218 & 337,000 & 571 \\
Depth $(\mathrm{ft})$ & 10.5 & 8.2 & 2 & 50.4 & 566 \\
\hline
\end{tabular}



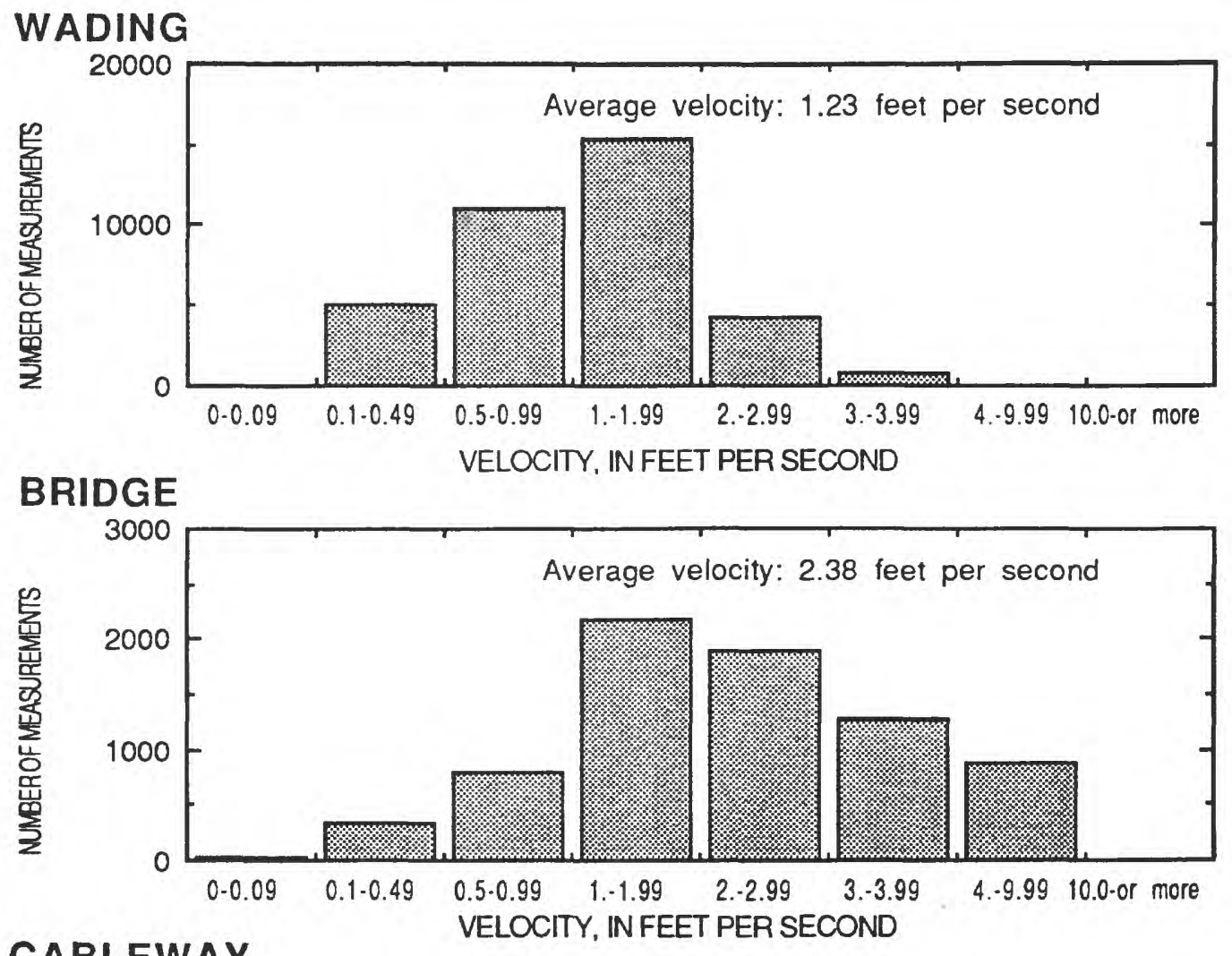

\section{CABLEWAY}

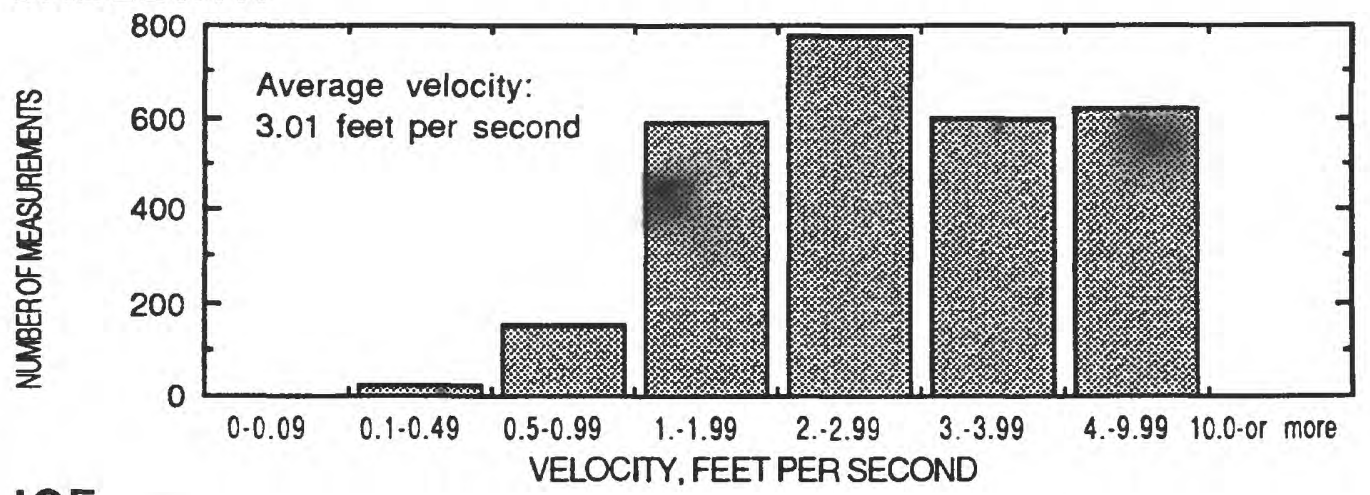

ICE

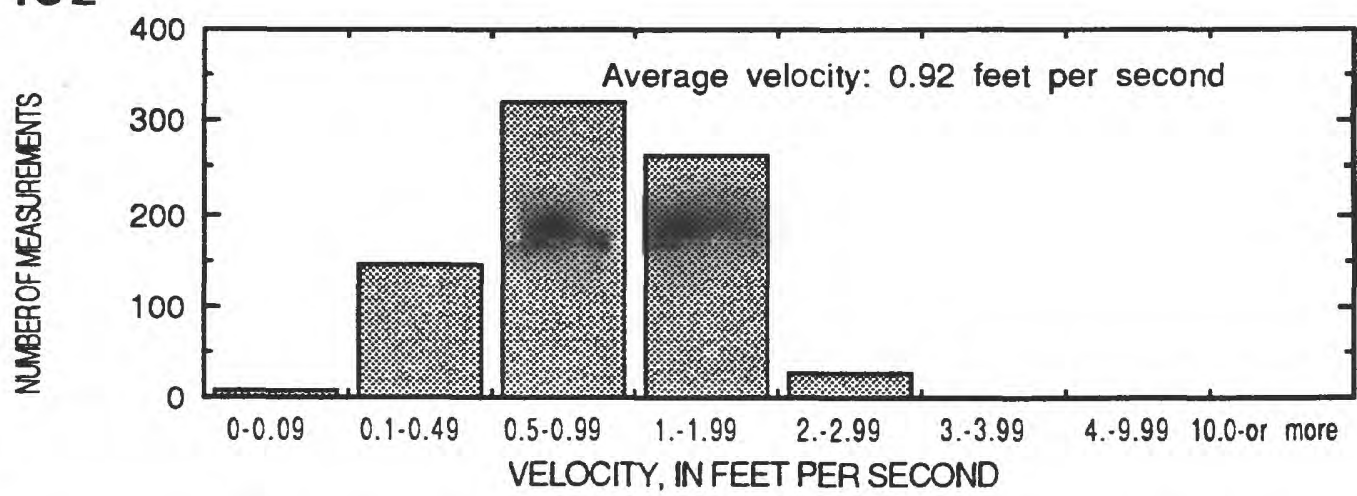

Figure 6.--Frequency distribution of velocity for wading, bridge, cableway, and ice measurement types. 


\section{Measurement Rating}

The combined data were grouped by measurement rating and analyzed. Those measurements without measurement-rating data and Ohio measurements rated good/fair on the photocopied forms were excluded from the statistical analysis. Because Ohio measurements rated good/fair are a small proportion of the total measurement data, they were excluded from the measurement-rating analysis instead of arbitrarily picking good or fair. The percentage of measurements attributed to each measurement rating--excellent, good, fair, and poor--is shown in figure 7. For any 12 measurements, approximately 7 are rated good and 4 are rated fair. The remaining measurement is usually rated poor. Less than 1 percent of measurements are rated excellent. Summary statistics for the combined data grouped by measurement rating are shown in tables 9a through 9d.

Velocity frequency distributions for the excellent, good, fair, and poor ratings are shown in figure 8. Velocity frequency distributions for each rating type, except for the poor ratings, look similar to the distribution for the entire data set. The velocity frequency distribution for poor ratings is skewed to velocities of less than $2 \mathrm{ft} / \mathrm{s}$.

\section{Analysis of State Data}

This section presents the analysis of the discharge measurement data by state (or WRD District). In most cases, the statistics are reported separately for each state. Not all states are reported separately because some Districts span state boundaries. Those states reported together are Vermont and New Hampshire and Massachusetts and Rhode Island. Delaware, even though it is part of a District with Maryland, is reported separately.

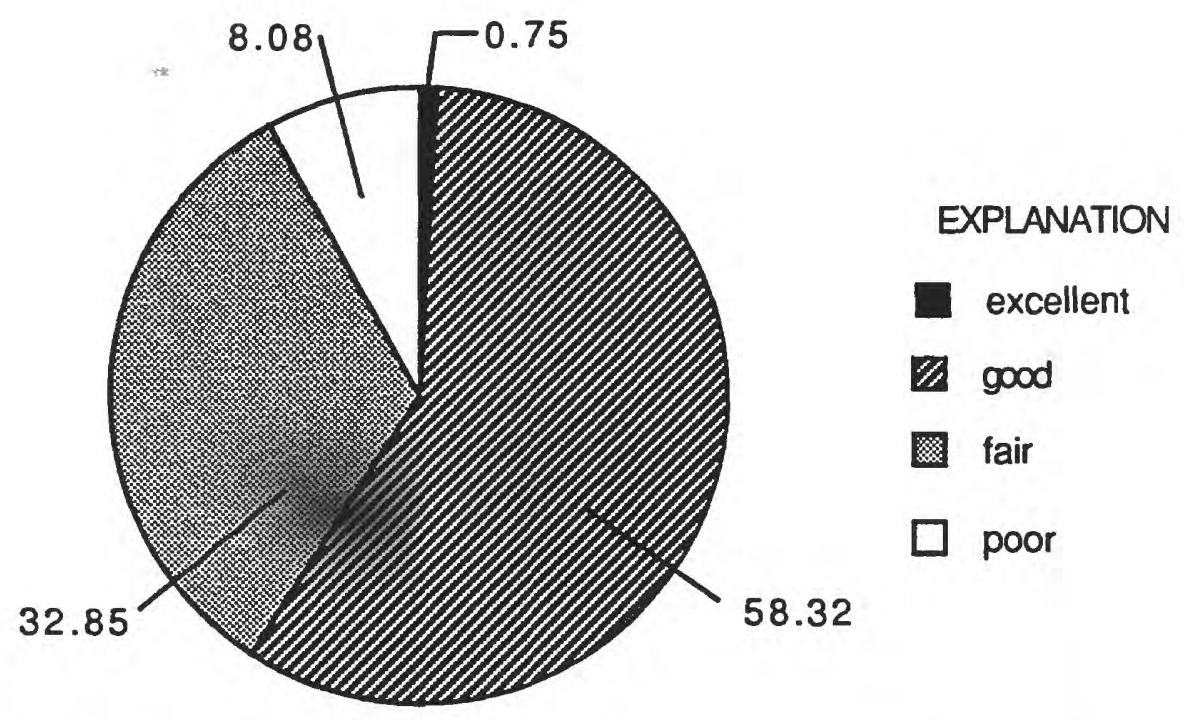

Figure 7.--Percentage of water year 1990 measurements by measurement rating (Ohio measurements rated good/fair are excluded.) 
Table 9a.--Summary statistics for discharge measurements rated excellent in water year 1990 [ft, feet; $f_{t}{ }^{2}$, square feet; ft/s, feet per second; $f_{t}{ }^{3} / s$, cubic feet per second]

\begin{tabular}{lccccc}
\hline Characteristic & Mean & $\begin{array}{c}\text { Standard } \\
\text { deviation }\end{array}$ & Low & High & Count \\
\hline Width $(\mathrm{ft})$ & 108.2 & 135.0 & 1.0 & 1,020 & 253 \\
Area $\left(\mathrm{ft}^{2}\right)$ & 513 & 1,653 & 0.7 & 15,800 & 252 \\
Velocity $(\mathrm{ft} / \mathrm{s})$ & 1.67 & 1.12 & 0.23 & 7.67 & 253 \\
Discharge $(\mathrm{ft} 3 / \mathrm{s})$ & 1,264 & 8,923 & 0 & 121,000 & 379 \\
Depth $(\mathrm{ft})$ & 2.3 & 2.8 & 0.2 & 21.2 & 252 \\
\hline
\end{tabular}

Table 9b.--Summary statistics for discharge measurements rated good in water year 1990 (Ohio cases rated goodlfair are not included)

[ft, feet; $f t^{2}$, square feet; ft/s, feet per second; $f t^{3} / s$, cubic feet per second]

\begin{tabular}{lccccc}
\hline Characteristic & Mean & $\begin{array}{c}\text { Standard } \\
\text { deviation }\end{array}$ & Low & High & Count \\
\hline Width $(\mathrm{ft})$ & 117.0 & 241.8 & 0.3 & 9,540 & 29,397 \\
Area $\left(\mathrm{ft}^{2}\right.$ ) & 761 & 3,611 & 0.01 & 100,000 & 29,203 \\
Velocity $(\mathrm{ft} / \mathrm{s})$ & 1.67 & 1.04 & 0.06 & 9.32 & 29,189 \\
Discharge $(\mathrm{ft} 3 / \mathrm{s})$ & 2,242 & 14,715 & -568 & 660,000 & 29,776 \\
Depth $(\mathrm{ft})$ & 2.5 & 3.5 & 0.01 & 50.4 & 29,186 \\
\hline
\end{tabular}

Table 9c.--Summary statistics for discharge measurements rated fair in water year 1990 (Ohio cases rated goodlfair are not included)

[ft, feet; $f_{t}{ }^{2}$, square feet; ft/s, feet per second; $f t^{3} / s$, cubic feet per second]

\begin{tabular}{lccccc} 
Characteristic & Mean & $\begin{array}{c}\text { Standard } \\
\text { deviation }\end{array}$ & Low & High & Count \\
\hline Width $(\mathrm{ft})$ & 92.0 & 229.9 & 0.1 & 13,675 & 16,398 \\
Area $\left(\mathrm{ft}^{2}\right)$ & 550 & 3,024 & 0 & 149,000 & 16,257 \\
Velocity $(\mathrm{ft} / \mathrm{s})$ & 1.43 & 1.11 & 0.02 & 12.66 & 16,244 \\
Discharge $\left(\mathrm{ft}^{3} \mathrm{~s} / \mathrm{s}\right)$ & 1,673 & 11,470 & -0.79 & 508,000 & 16,606 \\
Depth $(\mathrm{ft})$ & 2.0 & 3.1 & 0 & 51.5 & 16,237 \\
\hline
\end{tabular}

Table 9d.--Summary statistics for discharge measurements rated poor in water year 1990 [ft, feet; $f_{t}{ }^{2}$, square feet; $f t / s$, feet per second; $f_{t}{ }^{3} / s$, cubic feet per second]

\begin{tabular}{lccccc}
\hline Characteristic & Mean & $\begin{array}{c}\text { Standard } \\
\text { deviation }\end{array}$ & Low & High & Count \\
\hline Width $(\mathrm{ft})$ & 70.8 & 172.3 & 0.2 & 2,875 & 3,985 \\
Area $\left(\mathrm{ft}^{2}\right)$ & 321 & 1,341 & 0 & 25,900 & 3,916 \\
Velocity $(\mathrm{ft} / \mathrm{s})$ & 1.18 & 1.24 & 0 & 10.71 & 3,905 \\
Discharge $(\mathrm{ft} / \mathrm{s} / \mathrm{s})$ & 1,099 & 12,175 & -218 & 679,800 & 4,081 \\
Depth $(\mathrm{ft})$ & 1.6 & 2.9 & 0 & 41.9 & 3,907 \\
\hline
\end{tabular}




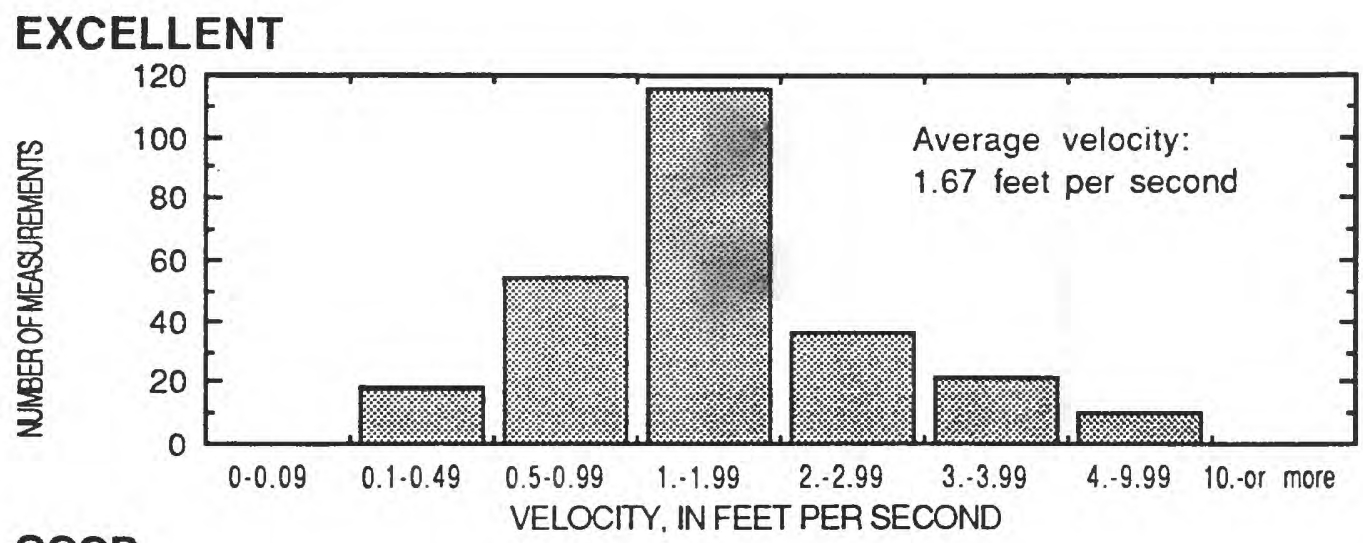

GOOD

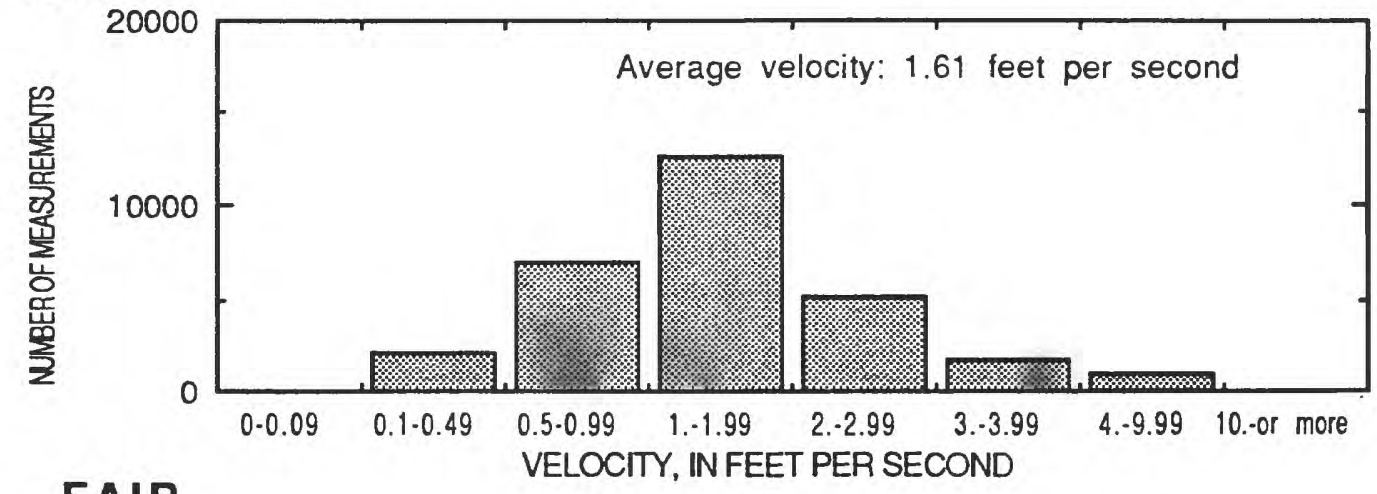

FAIR

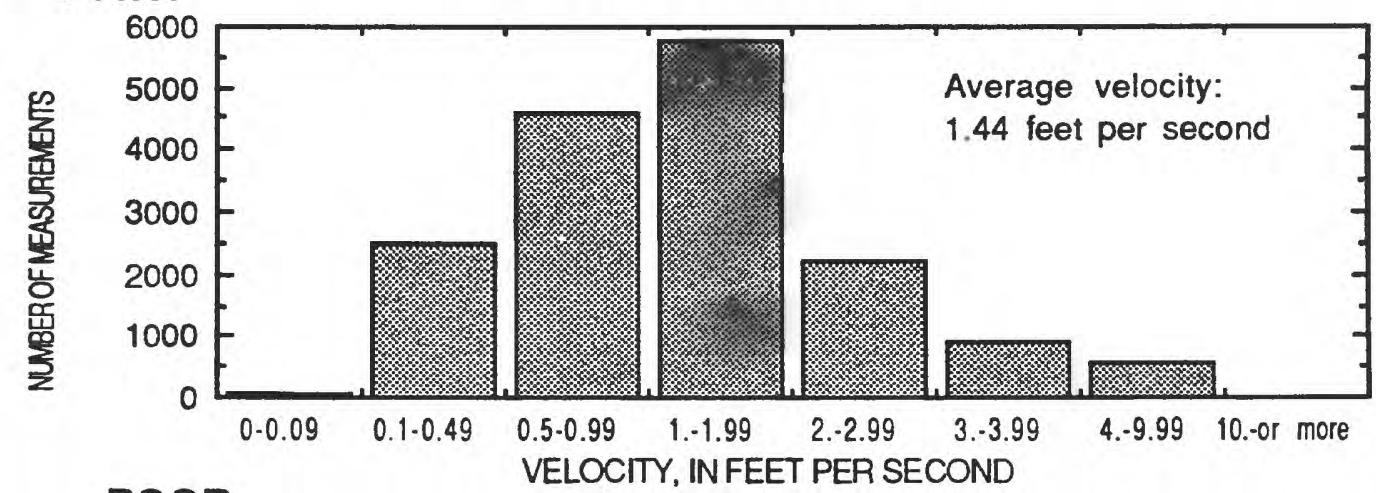

POOR

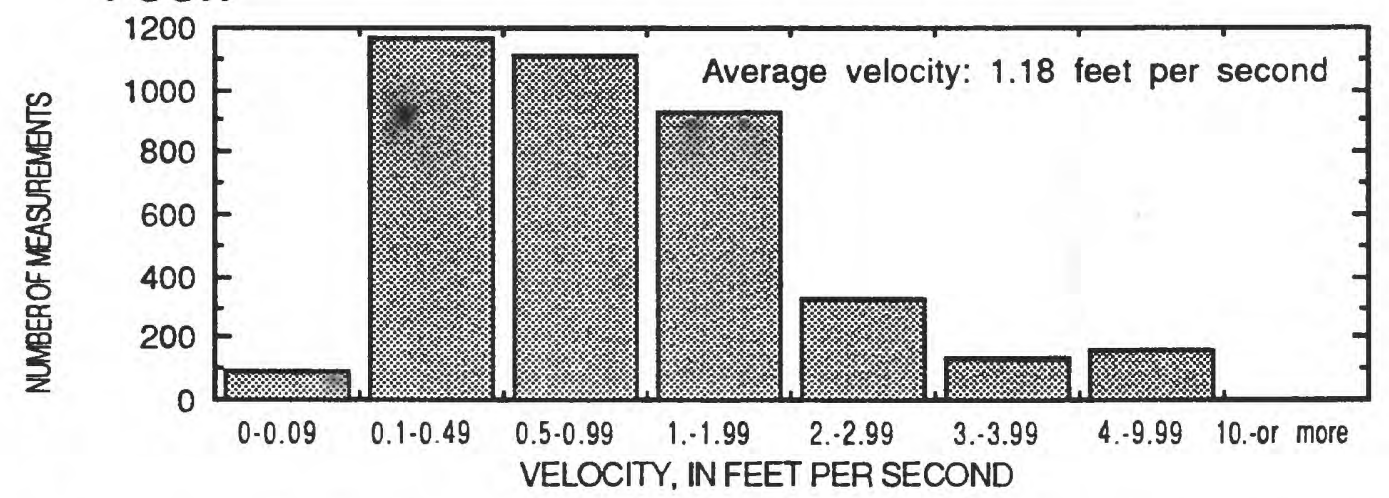

Figure 8.--Frequency distributions of velocity for excellent, good, fair, and poor measurement rating. 
Table 10.--Number of discharge measurement sites and average measurements per site listed by state

\begin{tabular}{|c|c|c|c|c|c|}
\hline State & $\begin{array}{l}\text { No. of } \\
\text { sites }\end{array}$ & $\begin{array}{c}\text { Average } \\
\text { measurements } \\
\text { per site }\end{array}$ & State & $\begin{array}{l}\text { No. of } \\
\text { sites }\end{array}$ & $\begin{array}{c}\text { Average } \\
\text { measurements } \\
\text { per site }\end{array}$ \\
\hline Alaska & 81 & 6.2 & Montana & 228 & 7.8 \\
\hline Alabama & 76 & 9.3 & North Carolina & 169 & 8.3 \\
\hline Arkansas & 49 & 7.6 & North Dakota & 73 & 11.7 \\
\hline Arizona & 102 & 11.4 & Nebraska & 116 & 13.8 \\
\hline California & 393 & 9.5 & New Jersey & 90 & 7.1 \\
\hline Connecticut & 42 & 6.9 & New Mexico & 130 & 10.4 \\
\hline Colorado & 237 & 12.5 & Nevada & 110 & 8.9 \\
\hline Delaware & 13 & 12.6 & New York & 208 & 7.2 \\
\hline Florida & 211 & 7.0 & Ohio & 128 & 6.5 \\
\hline Georgia & 111 & 10.3 & Oklahoma & 143 & 7.6 \\
\hline Hawaii & 79 & 7.2 & Oregon & 159 & 5.8 \\
\hline Iowa & 115 & 14.6 & Pennsylvania & 232 & 8.3 \\
\hline Idaho & 243 & 7.6 & Puerto Rico & 61 & 11.8 \\
\hline Illinois & 150 & 10.1 & South Carolina & 107 & 5.8 \\
\hline Indiana & 174 & 7.9 & South Dakota & 73 & 10.2 \\
\hline Kansas & 133 & 9.0 & Tennessee & 80 & 8.5 \\
\hline Kentucky & 100 & 9.0 & Texas & 280 & 7.6 \\
\hline Louisiana & 61 & 9.0 & Utah & 157 & 10.7 \\
\hline $\begin{array}{l}\text { Massachusetts \& } \\
\text { Rhode Island }\end{array}$ & 83 & 6.4 & $\begin{array}{l}\text { Vermont \& } \\
\text { New Hampshire }\end{array}$ & 62 & 6.2 \\
\hline Maryland & 75 & 7.9 & Virginia & 95 & 6.5 \\
\hline Maine & 47 & 4.5 & Washington & 241 & 6.4 \\
\hline Michigan & 140 & 8.5 & Wisconsin & 103 & 8.6 \\
\hline Minnesota & 62 & 9.4 & West Virginia & 76 & 5.6 \\
\hline Missouri & 104 & 11.5 & Wyoming & 125 & 11.7 \\
\hline Mississippi & 72 & 9.3 & & & \\
\hline
\end{tabular}

\section{Summary Statistics}

The total number of measurement sites and the average number of measurements made per site were computed from the data. The number of measurement sites per state ranges from 13 to 393 with 127 being the average. The median number of sites is 107 . The average number of measurements made per site for the water year ranged from a low of 4.5 for Maine to a high of 14.6 for Iowa. The average value is 9 measurements per site, and the median is 8.5 measurements per site. Table 10 lists by state the number of measurement sites and the average number of measurements per site.

Summary statistics for width, area, mean velocity, discharge, and mean flow depth data are listed by state in table 11. Included in the summary statistics are the mean, standard deviation, and number of values for each data type. 
Table 11.--Statistics by state for width, area, mean velocity, discharge, and mean flow depth for water year 1990

[S.D., standard deviation; No., number of measurements; $f t$, feet; $f^{2}{ }^{2}$, square feet; ft/s, feet per second; $\mathrm{ft}^{3} / \mathrm{s}$, cubic feet per second]

\begin{tabular}{|c|c|c|c|c|c|c|c|c|c|c|}
\hline \multirow[t]{2}{*}{ STATE } & \multicolumn{2}{|c|}{$\begin{array}{c}\text { WIDTH } \\
\text { (ft) }\end{array}$} & \multirow{2}{*}{\multicolumn{2}{|c|}{$\begin{array}{c}\text { AREA } \\
\left(\mathrm{ft}^{2}\right) \\
\text { Mean }\end{array}$}} & \multicolumn{2}{|c|}{$\begin{array}{c}\text { VELOCITY } \\
(\mathrm{ft} / \mathrm{s})\end{array}$} & \multicolumn{2}{|c|}{$\begin{array}{c}\text { DISCHARGE } \\
\left(\mathrm{ft}^{3} / \mathrm{s}\right)\end{array}$} & \multicolumn{2}{|c|}{$\begin{array}{c}\text { DEPTH } \\
\text { (ft) }\end{array}$} \\
\hline & $\begin{array}{l}\text { Mean } \\
\text { S.D. }\end{array}$ & No. & & & $\begin{array}{l}\text { Mean } \\
\text { S.D. }\end{array}$ & No. & $\begin{array}{c}\text { Mean } \\
\text { S.D. }\end{array}$ & No. & $\begin{array}{l}\text { Mean } \\
\text { S.D. }\end{array}$ & No. \\
\hline \multirow[t]{2}{*}{ Alaska } & 194.3 & & 1,604 & & 2.27 & & 8,021 & & 2.7 & \\
\hline & 376.4 & 485 & 5,160 & 479 & 1.57 & 477 & 40,161 & 500 & 3.9 & 477 \\
\hline \multirow[t]{2}{*}{ Alabama } & 106.9 & & & & 1.42 & & 1,635 & & 2.6 & \\
\hline & 243.9 & 698 & 1,856 & 693 & 1.00 & 693 & 7,206 & 696 & 3.1 & 692 \\
\hline \multirow[t]{2}{*}{ Arkansas } & 194.1 & & 2,941 & & 1.73 & & 12,566 & & 6.0 & \\
\hline & 295.5 & 322 & 7,779 & 320 & 1.61 & 320 & 44,655 & 369 & 7.7 & 320 \\
\hline \multirow[t]{2}{*}{ Arizona } & 73.1 & & 482 & & 1.32 & & 1,033 & & 2.2 & \\
\hline & 114.1 & 753 & 1,428 & 746 & 0.92 & 746 & 3,576 & 820 & 4.2 & 744 \\
\hline \multirow[t]{2}{*}{ Califomia } & 54.6 & & 179 & & 1.35 & & 357 & & 1.4 & \\
\hline & 88.6 & 3,400 & 596 & 3,365 & 1.04 & 3,366 & 1,501 & 3,713 & 1.8 & 3,364 \\
\hline \multirow{2}{*}{ Colorado } & 48.8 & & 76 & & 1.71 & & 209 & & 1.0 & \\
\hline & 54.3 & 2,886 & 155 & 2,871 & 1.11 & 2,871 & 633 & 2,953 & 0.9 & 2,869 \\
\hline \multirow[t]{2}{*}{ Connecticut } & 79.5 & & 335 & & 1.53 & & 911 & & 2.0 & \\
\hline & 144.4 & 289 & 1,261 & 289 & 1.11 & 289 & 3,899 & 289 & 2.0 & 289 \\
\hline \multirow[t]{2}{*}{ Delaware } & 37.8 & & 103 & & 1.05 & & 135 & & 1.7 & \\
\hline & 29.7 & 164 & 191 & 164 & 0.70 & 164 & 407 & 164 & 1.9 & 164 \\
\hline \multirow[t]{2}{*}{ Florida } & 103.3 & & 798 & & 0.74 & & 1,151 & & 2.5 & \\
\hline & 464.5 & 1,396 & 5,389 & 1,375 & 0.50 & 1,376 & 9,110 & 1,418 & 3.5 & 1,361 \\
\hline \multirow[t]{2}{*}{ Georgia } & 161.2 & & 1,165 & & 1.55 & & 3,104 & & 4.1 & \\
\hline & 279.2 & 1,124 & 2,947 & 1,122 & 1.10 & 1,122 & 10,189 & 1,145 & 4.2 & 1,122 \\
\hline \multirow[t]{2}{*}{ Hawaii } & 12.1 & & 16 & & 0.97 & & 31 & & 1.0 & \\
\hline & 13.1 & 566 & 33 & 563 & 0.62 & 562 & 278 & 566 & 0.6 & 563 \\
\hline \multirow[t]{2}{*}{ Iowa } & 241.0 & & 2,113 & & 2.05 & & 6,720 & & 4.7 & \\
\hline & 332.0 & 1,664 & 4,187 & 1,656 & 1.44 & 1,654 & 12,413 & 1,673 & 4.9 & 1,656 \\
\hline \multirow[t]{2}{*}{ Idaho } & 113.0 & & 612 & & 2.08 & & 1,566 & & 2.6 & \\
\hline & 146.0 & 1,730 & 1,827 & 1,722 & 1.33 & 1,720 & 4,810 & 1,818 & 3.6 & 1,721 \\
\hline \multirow[t]{2}{*}{ Illinois } & 106.0 & & 617 & & 1.37 & & 1,330 & & 2.7 & \\
\hline & 214.0 & 1,495 & 1,832 & 1,485 & 0.88 & 1,482 & 4,553 & 1,495 & 3.3 & 1,485 \\
\hline \multirow[t]{2}{*}{ Indiana } & $\begin{array}{r}95.0 \\
1260\end{array}$ & & 412 & & 1.43 & & 947 & & 2.3 & \\
\hline & 126.0 & 1,364 & 1,102 & 1,361 & 0.83 & 1,359 & 3,151 & 1,361 & 2.4 & 1,361 \\
\hline
\end{tabular}


Table 11.--Statistics by state for width, area, mean velocity, discharge, and mean flow depth for water year 1990

[continued; S.D., standard deviation; No., number of measurements; ft, feet; $f t^{2}$, square feet; ft/s, feet per second; $f^{3} / s$, cubic feet per second]

\begin{tabular}{|c|c|c|c|c|c|c|c|c|c|c|}
\hline \multirow[t]{2}{*}{ STATE } & \multicolumn{2}{|c|}{$\begin{array}{l}\text { WIDTH } \\
(\mathbf{f t})\end{array}$} & \multicolumn{2}{|c|}{$\begin{array}{c}\text { AREA } \\
\left(\mathrm{ft}^{2}\right)\end{array}$} & \multicolumn{2}{|c|}{$\begin{array}{l}\text { VELOCITY } \\
(\mathrm{ft} / \mathrm{s})\end{array}$} & \multicolumn{2}{|c|}{$\begin{array}{c}\text { DISCHARGE } \\
\left(\mathrm{ft}^{3} / \mathrm{s}\right)\end{array}$} & \multicolumn{2}{|c|}{$\begin{array}{l}\text { DEPTH } \\
\text { (ft) }\end{array}$} \\
\hline & $\begin{array}{l}\text { Mean } \\
\text { S.D. }\end{array}$ & No. & $\begin{array}{l}\text { Mean } \\
\text { S.D. }\end{array}$ & No. & $\begin{array}{l}\text { Mean } \\
\text { S.D. }\end{array}$ & No. & $\begin{array}{c}\text { Mean } \\
\text { S.D. }\end{array}$ & No. & $\begin{array}{l}\text { Mean } \\
\text { S.D. }\end{array}$ & No. \\
\hline Kansas & $\begin{array}{r}96.5 \\
171.1\end{array}$ & 1,159 & $\begin{array}{l}339 \\
974\end{array}$ & 1,153 & $\begin{array}{l}1.35 \\
0.81\end{array}$ & 1,152 & $\begin{array}{r}788 \\
2,999\end{array}$ & 1,185 & $\begin{array}{l}1.8 \\
2.5\end{array}$ & 1,153 \\
\hline Kentucky & $\begin{array}{l}101.3 \\
138.2\end{array}$ & 898 & $\begin{array}{r}763 \\
4,256\end{array}$ & 888 & $\begin{array}{l}1.48 \\
0.96\end{array}$ & 889 & $\begin{array}{r}1,741 \\
11,280\end{array}$ & 892 & $\begin{array}{l}3.3 \\
4.9\end{array}$ & 888 \\
\hline Louisiana & $\begin{array}{l}210.8 \\
346.9\end{array}$ & 370 & $\begin{array}{r}4,211 \\
12,515\end{array}$ & 363 & $\begin{array}{l}1.23 \\
3.77\end{array}$ & 359 & $\begin{array}{r}9,330 \\
34,494\end{array}$ & 416 & $\begin{array}{r}7.8 \\
12.7\end{array}$ & 362 \\
\hline $\begin{array}{l}\text { Massachusetts \& } \\
\text { Rhode Island }\end{array}$ & $\begin{array}{l}50.3 \\
41.6\end{array}$ & 525 & $\begin{array}{l}129 \\
392\end{array}$ & 515 & $\begin{array}{l}1.53 \\
0.80\end{array}$ & 514 & $\begin{array}{r}280 \\
1,251\end{array}$ & 520 & $\begin{array}{l}1.8 \\
1.8\end{array}$ & 515 \\
\hline Maryland & $\begin{array}{l}54.1 \\
75.6\end{array}$ & 591 & $\begin{array}{l}115 \\
375\end{array}$ & 591 & $\begin{array}{l}1.24 \\
0.75\end{array}$ & 591 & $\begin{array}{l}209 \\
952\end{array}$ & 591 & $\begin{array}{l}1.3 \\
1.3\end{array}$ & 591 \\
\hline Maine & $\begin{array}{l}205.0 \\
183.0\end{array}$ & 206 & $\begin{array}{r}892 \\
1,482\end{array}$ & 206 & $\begin{array}{l}1.72 \\
1.00\end{array}$ & 206 & $\begin{array}{l}2,060 \\
4,923\end{array}$ & 210 & $\begin{array}{l}3.1 \\
2.7\end{array}$ & 206 \\
\hline Michigan & $\begin{array}{l}84.3 \\
82.4\end{array}$ & 1,184 & $\begin{array}{l}266 \\
624\end{array}$ & 1,183 & $\begin{array}{l}1.45 \\
0.80\end{array}$ & 1,183 & $\begin{array}{r}497 \\
1,569\end{array}$ & 1,183 & $\begin{array}{l}2.1 \\
1.8\end{array}$ & 1,183 \\
\hline Minnesota & $\begin{array}{l}70.7 \\
81.0\end{array}$ & 557 & $\begin{array}{l}257 \\
777\end{array}$ & 545 & $\begin{array}{l}1.14 \\
0.96\end{array}$ & 545 & $\begin{array}{r}449 \\
1,752\end{array}$ & 555 & $\begin{array}{l}1.8 \\
2.3\end{array}$ & 545 \\
\hline Missouri & $\begin{array}{l}384.0 \\
618.2\end{array}$ & 1,179 & $\begin{array}{r}5,569 \\
13,106\end{array}$ & 1,171 & $\begin{array}{l}2.12 \\
1.34\end{array}$ & 1,169 & $\begin{array}{l}21,931 \\
61,658\end{array}$ & 1,183 & $\begin{array}{l}5.9 \\
7.0\end{array}$ & 1,171 \\
\hline Mississippi & $\begin{array}{l}167.4 \\
349.5\end{array}$ & 661 & $\begin{array}{l}1,283 \\
3,561\end{array}$ & 657 & $\begin{array}{l}1.54 \\
0.95\end{array}$ & 656 & $\begin{array}{l}3,077 \\
9,388\end{array}$ & 662 & $\begin{array}{l}4.2 \\
4.7\end{array}$ & 657 \\
\hline Montana & $\begin{array}{r}90.8 \\
113.6\end{array}$ & 1,716 & $\begin{array}{l}322 \\
800\end{array}$ & 1,711 & $\begin{array}{l}1.91 \\
1.20\end{array}$ & 1,713 & $\begin{array}{r}910 \\
2,946\end{array}$ & 1,768 & $\begin{array}{l}1.8 \\
1.9\end{array}$ & 1,709 \\
\hline North Carolina & $\begin{array}{l}60.4 \\
61.1\end{array}$ & 1,048 & $\begin{array}{l}189 \\
374\end{array}$ & 1,045 & $\begin{array}{l}1.20 \\
0.84\end{array}$ & 1,045 & $\begin{array}{l}319 \\
837\end{array}$ & 1,052 & $\begin{array}{l}1.9 \\
2.0\end{array}$ & 1,045 \\
\hline North Dakota & $\begin{array}{r}50.7 \\
115.4\end{array}$ & 617 & $\begin{array}{l}174 \\
725\end{array}$ & 606 & $\begin{array}{l}0.89 \\
0.57\end{array}$ & 604 & $\begin{array}{r}182 \\
1,473\end{array}$ & 845 & $\begin{array}{l}1.2 \\
1.7\end{array}$ & 599 \\
\hline Nebraska & $\begin{array}{l}133.8 \\
313.9\end{array}$ & 1,596 & $\begin{array}{l}232 \\
653\end{array}$ & 1,588 & $\begin{array}{l}1.60 \\
0.85\end{array}$ & 1,586 & $\begin{array}{r}636 \\
2,969\end{array}$ & 1,595 & $\begin{array}{l}1.3 \\
1.6\end{array}$ & 1,587 \\
\hline New Jersey & $\begin{array}{r}64.1 \\
107.0 \\
\end{array}$ & 640 & $\begin{array}{l}217 \\
677 \\
\end{array}$ & 627 & $\begin{array}{l}1.13 \\
0.70 \\
\end{array}$ & 627 & $\begin{array}{r}292 \\
1,133 \\
\end{array}$ & 630 & $\begin{array}{l}1.8 \\
1.7 \\
\end{array}$ & 627 \\
\hline
\end{tabular}


Table 11.--Statistics by state for width, area, mean velocity, discharge, and mean flow depth for water year 1990

[continued; S.D., standard deviation; No., number of measurements; $f t, f e e t ; f t^{2}$, square feet; $\mathrm{ft} / \mathrm{s}$, feet per second; $\mathrm{ft}^{3} / \mathrm{s}$, cubic feet per second]

\begin{tabular}{|c|c|c|c|c|c|c|c|c|c|c|}
\hline \multirow[t]{2}{*}{ STATE } & \multicolumn{2}{|c|}{$\begin{array}{c}\text { WIDTH } \\
(\mathrm{ft})\end{array}$} & \multicolumn{2}{|c|}{$\begin{array}{c}\text { AREA } \\
\left(\mathrm{ft}^{2}\right)\end{array}$} & \multicolumn{2}{|c|}{$\begin{array}{l}\text { VELOCITY } \\
(\mathrm{ft} / \mathrm{s})\end{array}$} & \multicolumn{2}{|c|}{$\begin{array}{l}\text { DISCHARGE } \\
\left(\mathrm{ft}^{3} / \mathrm{s}\right)\end{array}$} & \multicolumn{2}{|c|}{$\begin{array}{l}\text { DEPTH } \\
\text { (ft) }\end{array}$} \\
\hline & $\begin{array}{l}\text { Mean } \\
\text { S.D. }\end{array}$ & No. & $\begin{array}{l}\text { Mean } \\
\text { S.D. }\end{array}$ & No. & $\begin{array}{l}\text { Mean } \\
\text { S.D. }\end{array}$ & No. & $\begin{array}{l}\text { Mean } \\
\text { S.D. }\end{array}$ & No. & $\begin{array}{l}\text { Mean } \\
\text { S.D. }\end{array}$ & No. \\
\hline \multirow[t]{2}{*}{ New Mexico } & 50.5 & & 77 & & 1.54 & & 193 & & 1.1 & \\
\hline & 58.0 & 1,318 & 121 & 1,303 & 0.91 & 1,303 & 588 & 1,366 & 0.9 & 1,302 \\
\hline \multirow[t]{2}{*}{ Nevada } & 27.7 & & 42 & & 1.29 & & 100 & & 1.0 & \\
\hline & 32.0 & 964 & 75 & 959 & 1.01 & 956 & 360 & 977 & 1.0 & 958 \\
\hline \multirow[t]{2}{*}{ New York } & 98.8 & & 291 & & 1.55 & & 738 & & 1.8 & \\
\hline & 117.3 & 1,499 & 812 & 1,486 & 1.04 & 1,486 & 2,976 & 1,487 & 1.7 & 1,486 \\
\hline \multirow[t]{2}{*}{ Ohio } & 110.0 & & 420 & & 1.72 & & 1,087 & & 2.4 & \\
\hline & 108.0 & 827 & 870 & 827 & 1.05 & 827 & 3,079 & 827 & 2.4 & 827 \\
\hline \multirow[t]{2}{*}{ Oklahoma } & 169.0 & & 1,083 & & 1.69 & & 4,830 & & 3.2 & \\
\hline & 337.0 & 1,030 & 3,230 & 984 & 1.29 & 978 & 19,257 & 1,070 & 4.4 & 981 \\
\hline \multirow[t]{2}{*}{ Oregon } & 98.5 & & 439 & & 1.83 & & 1,049 & & 2.6 & \\
\hline & 101.0 & 888 & 1,641 & 885 & 1.29 & 885 & 3,868 & 912 & 3.0 & 912 \\
\hline \multirow[t]{2}{*}{ Pennsylvania } & 135.0 & & 554 & & 1.43 & & 1,071 & & 1.9 & \\
\hline & 208.0 & 1,918 & 2,040 & 1,890 & 0.80 & 1,889 & 4,179 & 1,895 & 2.2 & 1,890 \\
\hline \multirow[t]{2}{*}{ Puerto Rico } & 37.3 & & 38 & & 0.89 & & 48 & & 0.8 & \\
\hline & 27.9 & 704 & 63 & 703 & 0.64 & 704 & 137 & 722 & 0.8 & 703 \\
\hline \multirow{2}{*}{ South Carolina } & 151.0 & & 1,017 & & 1.20 & & 1,814 & & 3.0 & \\
\hline & 413.0 & 614 & 3,729 & 608 & 0.74 & 609 & 6,788 & 619 & 3.6 & 608 \\
\hline \multirow{2}{*}{ South Dakota } & 39.0 & & 137 & & 1.12 & & 227 & & 0.9 & \\
\hline & 91.0 & 1,168 & 1,019 & 1,159 & 0.66 & 1,157 & 2,112 & 1,417 & 1.3 & 1,159 \\
\hline \multirow[t]{2}{*}{ Tennessee } & 121.0 & & 751 & & 1.55 & & 1,902 & & 2.9 & \\
\hline & 205.0 & 642 & 2,747 & 637 & 1.04 & 638 & 10,804 & 676 & 4.0 & 637 \\
\hline \multirow[t]{2}{*}{ Texas } & 144.8 & & 1,057 & & 1.39 & & 3,149 & & 2.8 & \\
\hline & 428.0 & 2,112 & 3,648 & 2,103 & 1.06 & 2,099 & 13,188 & 2,106 & 4.3 & 2,099 \\
\hline \multirow[t]{2}{*}{ Utah } & 43.2 & & 82 & & 1.43 & & 152 & & 1.1 & \\
\hline & 57.2 & 1,573 & 206 & 1,555 & 1.05 & 1,556 & 456 & 1,651 & 1.0 & 1,555 \\
\hline \multirow[t]{2}{*}{ Virginia } & 144.0 & & 575 & & 1.44 & & 1,079 & & 2.8 & \\
\hline & 149.0 & 612 & 927 & 612 & 0.86 & 612 & 2,378 & 615 & 2.6 & 612 \\
\hline Vermont \& & 88.9 & & 337 & & 1.72 & & 893 & & 2.4 & \\
\hline New Hampshire & 85.4 & 380 & 789 & 372 & 1.16 & 372 & 2,879 & 374 & 2.7 & 372 \\
\hline
\end{tabular}


Table 11.--Statistics by state for width, area, mean velocity, discharge, and mean flow depth for water year 1990

Icontinued; S.D., standard deviation; No., number of measurements; $f t$, feet: $f t^{2}$, square feet; ft/s, feet per second; $\mathrm{ft}^{3} / \mathrm{s}$, cubic feet per second]

\begin{tabular}{|c|c|c|c|c|c|c|c|c|c|c|}
\hline \multirow[t]{2}{*}{ STATE } & \multicolumn{2}{|c|}{$\begin{array}{c}\text { WIDTH } \\
\text { (ft) }\end{array}$} & \multirow{2}{*}{$\begin{array}{c}\text { AREA } \\
\left(\mathrm{ft}^{2}\right) \\
\text { Mean } \\
\text { S.D. }\end{array}$} & & \multicolumn{2}{|c|}{$\begin{array}{c}\text { VELOCITY } \\
(\mathrm{ft} / \mathrm{s})\end{array}$} & \multicolumn{2}{|c|}{$\begin{array}{c}\text { DISCHARGE } \\
\left(\mathrm{ft}^{3} / \mathrm{s}\right)\end{array}$} & \multicolumn{2}{|c|}{$\begin{array}{c}\text { DEPTH } \\
\text { (ft) }\end{array}$} \\
\hline & $\begin{array}{l}\text { Mean } \\
\text { S.D. }\end{array}$ & No. & & No. & $\begin{array}{c}\text { Mean } \\
\text { S.D. }\end{array}$ & No. & $\begin{array}{l}\text { Mean } \\
\text { S.D. }\end{array}$ & No. & $\begin{array}{l}\text { Mean } \\
\text { S.D. }\end{array}$ & No. \\
\hline Washington & $\begin{array}{l}107.3 \\
155.0\end{array}$ & 1,479 & $\begin{array}{l}1,055 \\
4,831\end{array}$ & 1,465 & $\begin{array}{l}2.24 \\
1.61\end{array}$ & 1,457 & $\begin{array}{r}4,535 \\
21,980\end{array}$ & 1,508 & $\begin{array}{l}3.1 \\
5.2\end{array}$ & 1,463 \\
\hline Wisconsin & $\begin{array}{l}109.9 \\
147.2\end{array}$ & 878 & $\begin{array}{r}460 \\
1,170\end{array}$ & 876 & $\begin{array}{l}1.45 \\
0.91\end{array}$ & 876 & $\begin{array}{l}1,014 \\
3,649\end{array}$ & 877 & $\begin{array}{l}2.2 \\
2.5\end{array}$ & 876 \\
\hline West Virginia & $\begin{array}{l}154.4 \\
162.3\end{array}$ & 421 & $\begin{array}{r}938 \\
2,198\end{array}$ & 419 & $\begin{array}{l}1.62 \\
1.01\end{array}$ & 419 & $\begin{array}{l}2,101 \\
7,309\end{array}$ & 419 & $\begin{array}{l}3.3 \\
3.5\end{array}$ & 418 \\
\hline Wyoming & $\begin{array}{l}65.1 \\
73.6\end{array}$ & 1,243 & $\begin{array}{l}118 \\
217\end{array}$ & 1,240 & $\begin{array}{l}1.65 \\
1.11\end{array}$ & 1,239 & $\begin{array}{l}379 \\
803\end{array}$ & 1,430 & $\begin{array}{l}1.2 \\
1.1\end{array}$ & 1,239 \\
\hline
\end{tabular}

Mean velocities in all Districts ranged from $0.74 \mathrm{ft} / \mathrm{s}$ to $2.27 \mathrm{ft} / \mathrm{s}$. The lowest mean velocity was in Florida. The three next lowest mean velocities were in North Dakota, Puerto Rico, and Hawaii. The highest mean velocity was in Alaska. The next three highest mean velocities were in Washington, Missouri, and Idaho. The median mean velocity for the Districts was $1.45 \mathrm{ft} / \mathrm{s}$.

Mean discharges by state ranged from a low of $30.9 \mathrm{ft}^{3} / \mathrm{s}$ to a high of $21,931 \mathrm{ft}^{3} / \mathrm{s}$. The highest mean discharge was in Missouri and the next three highest discharges were in Arkansas, Louisiana, and Alaska. The median mean discharge was $1,014 \mathrm{ft}^{3} / \mathrm{s}$.

Mean district measurement depths ranged from $0.8 \mathrm{ft}$ to $7.8 \mathrm{ft}$. The shallowest mean depth was computed for Puerto Rico and the deepest for Louisiana. The median depth was $2.2 \mathrm{ft}$ for the Districts (or states).

Frequency Analysis of Velocity, Depth, Rating Type and Measurement type

Distributions for mean velocities and mean depths and percentages of measurements grouped by measurement rating and by measurement type were computed for each state or pair of states. Data for each state(s) are shown in two bar charts and one or two pie charts. The bar charts show the velocity and depth frequency distributions. One pie chart shows the proportion of discharge measurements rated excellent, good, fair, or poor. The other pie chart depicts the proportion of discharge measurements made using the various measurement types: wading, bridge, cableway, boat, or ice. This last pie chart is not available for states in districts that had photocopied data (Alaska, Maine, Ohio, and Virginia). Figures 9 through 57 are the District figures arranged alphabetically by state. 

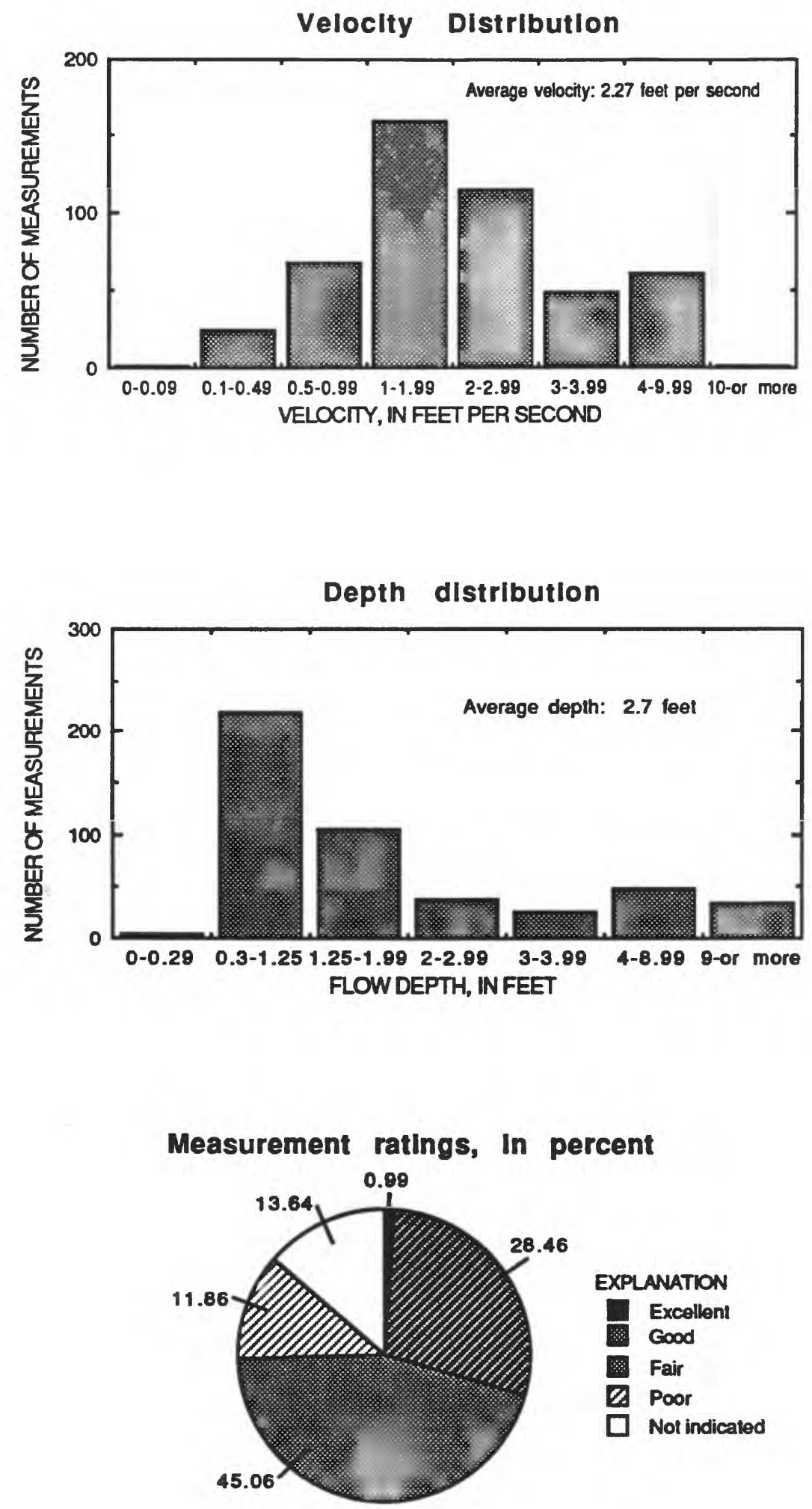

Figure 9.--Alaska's velocity and depth frequency distributions and percentage of measurements by measurement rating for water year 1990. 

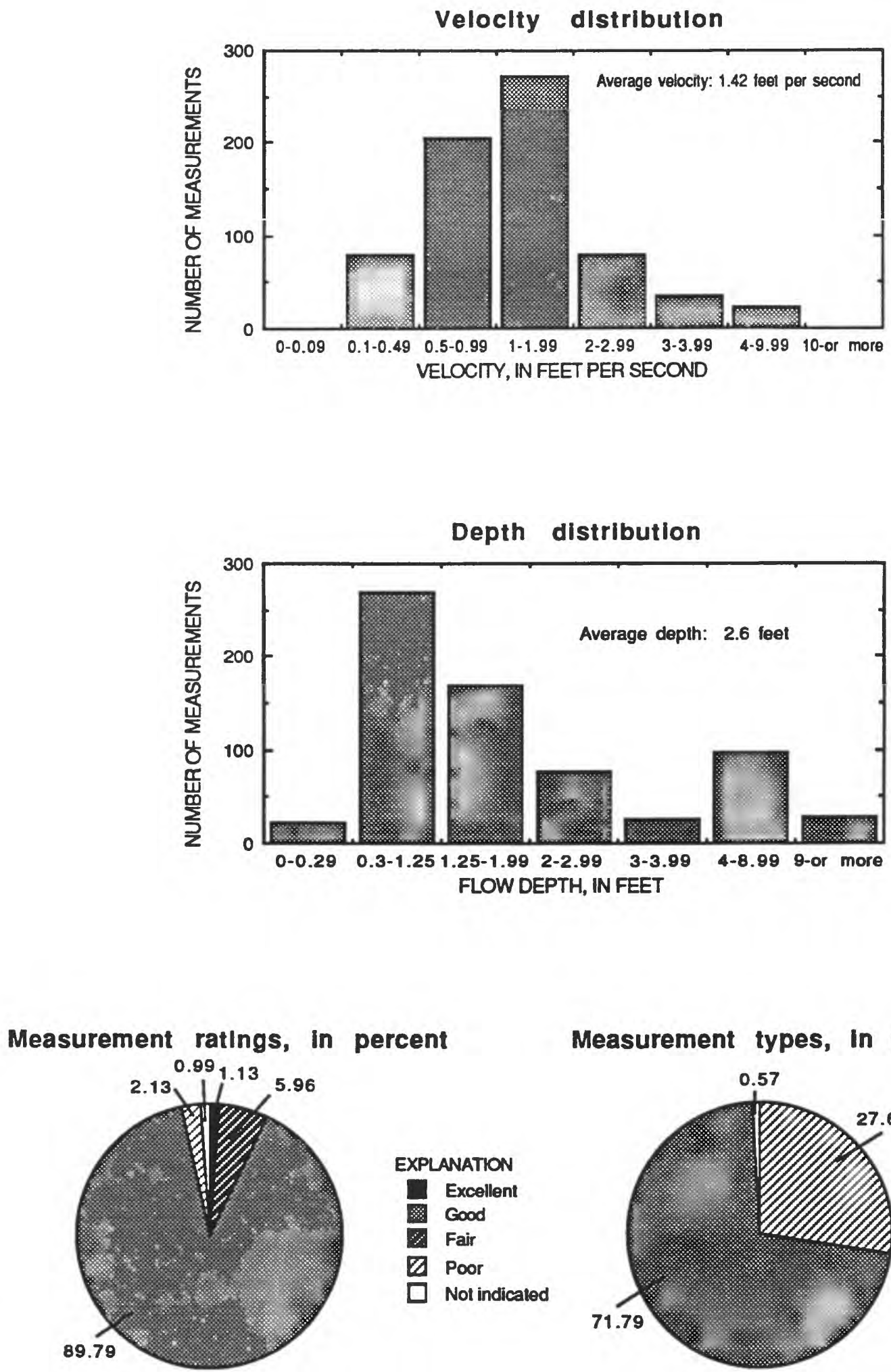

percent

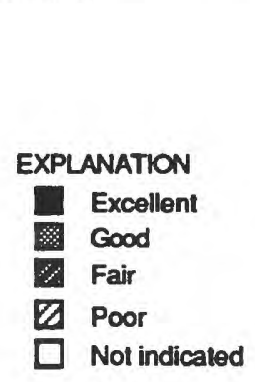

Measurement types, in percent

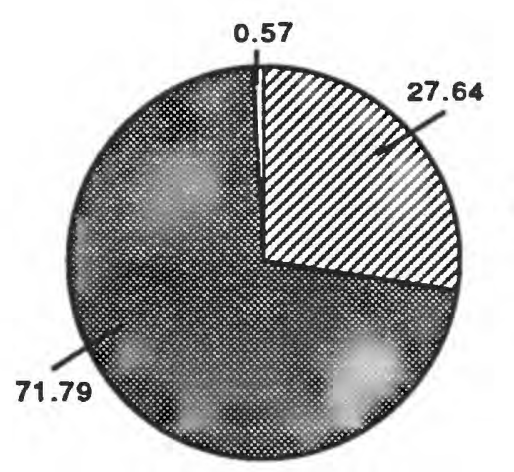

EXPLANATION

$\square$ Bridge

Wading

Not indicaled

Figure 10.--Alabama's velocity and depth frequency distributions and percentage of measurements by measurement rating and by measurement type for water year 1990 . 

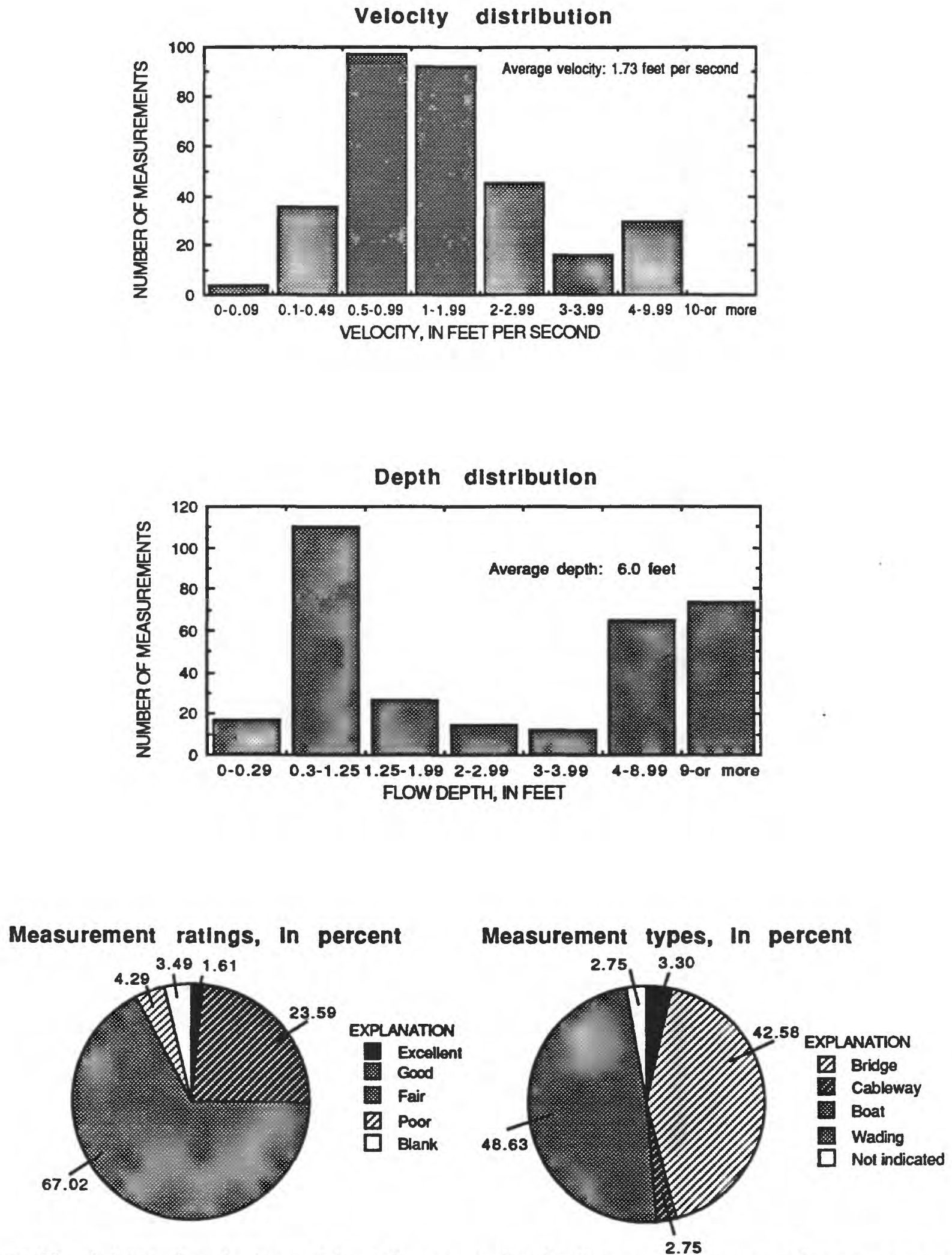

Figure 11.--Arkansas's velocity and depth frequency distributions and percentage of measurements by measurement rating and by measurement type for water year 1990 . 

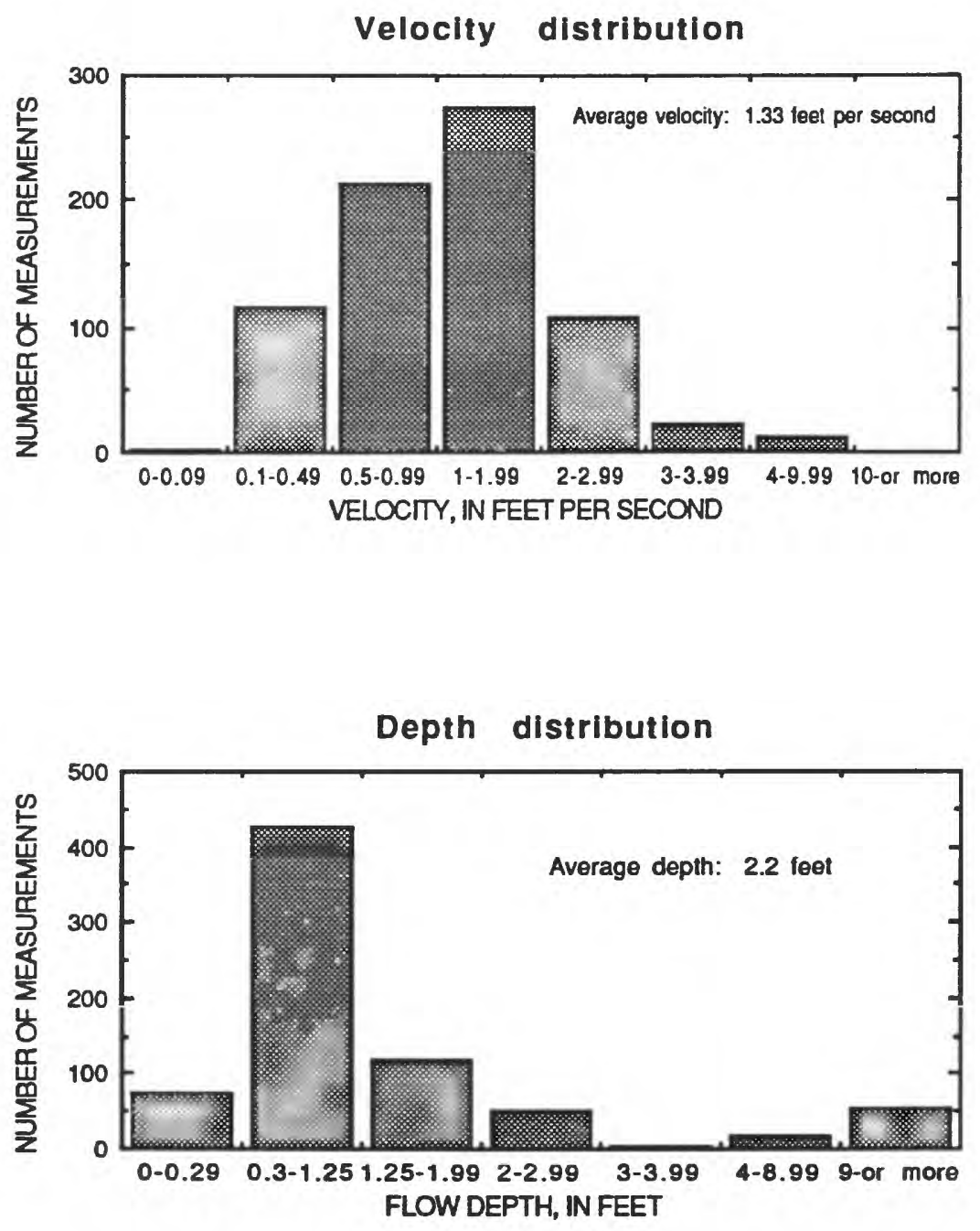

Measurement ratings, in percent

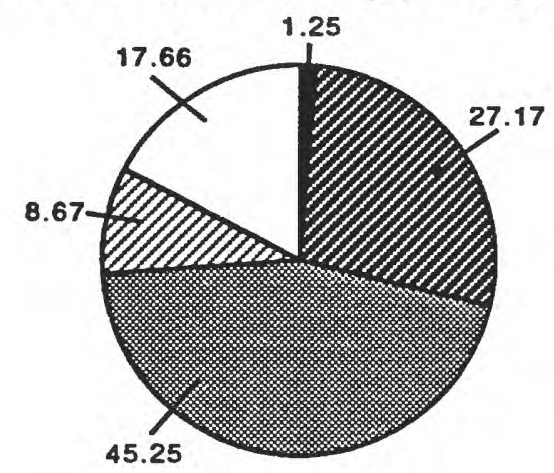

EXPLANATION

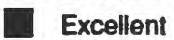

网 Good

2 Fair

8 Poor

Nol indicated
Measurement types, in percent

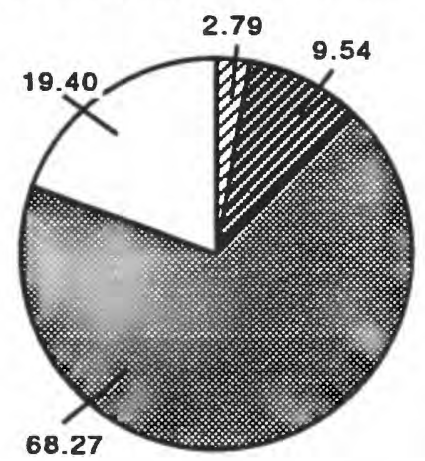

EXPLANATION

E Bridge

Cableway

济 Wading

$\square$ Not indicated

Figure 12.--Arizona's velocity and depth distributions and percentage of measurements by measurement rating and by measurement type for water year 1990 . 

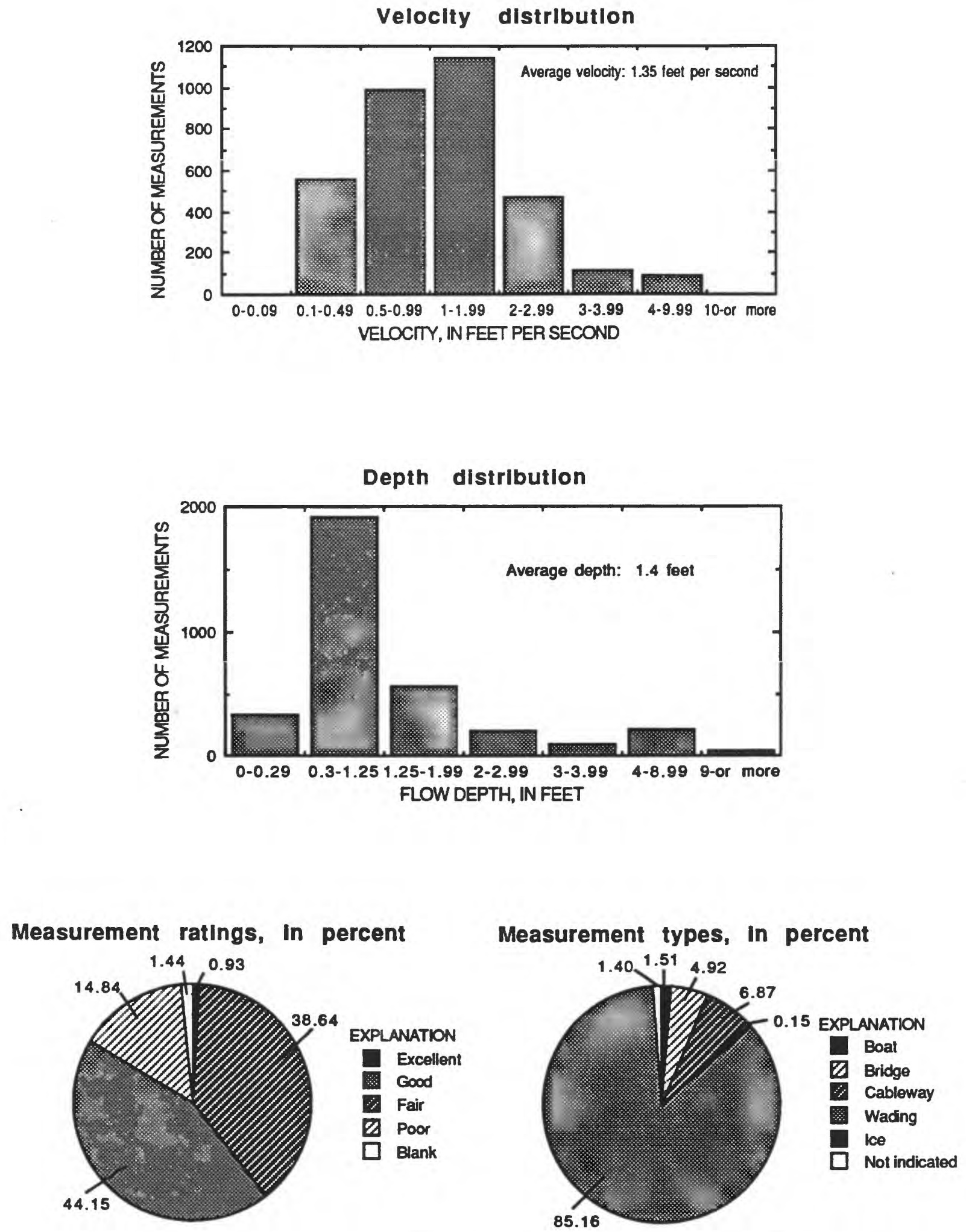

Figure 13.--California's velocity and depth frequency distributions and percentage of measurements by measurement rating and by measurement type for water year 1990 . 

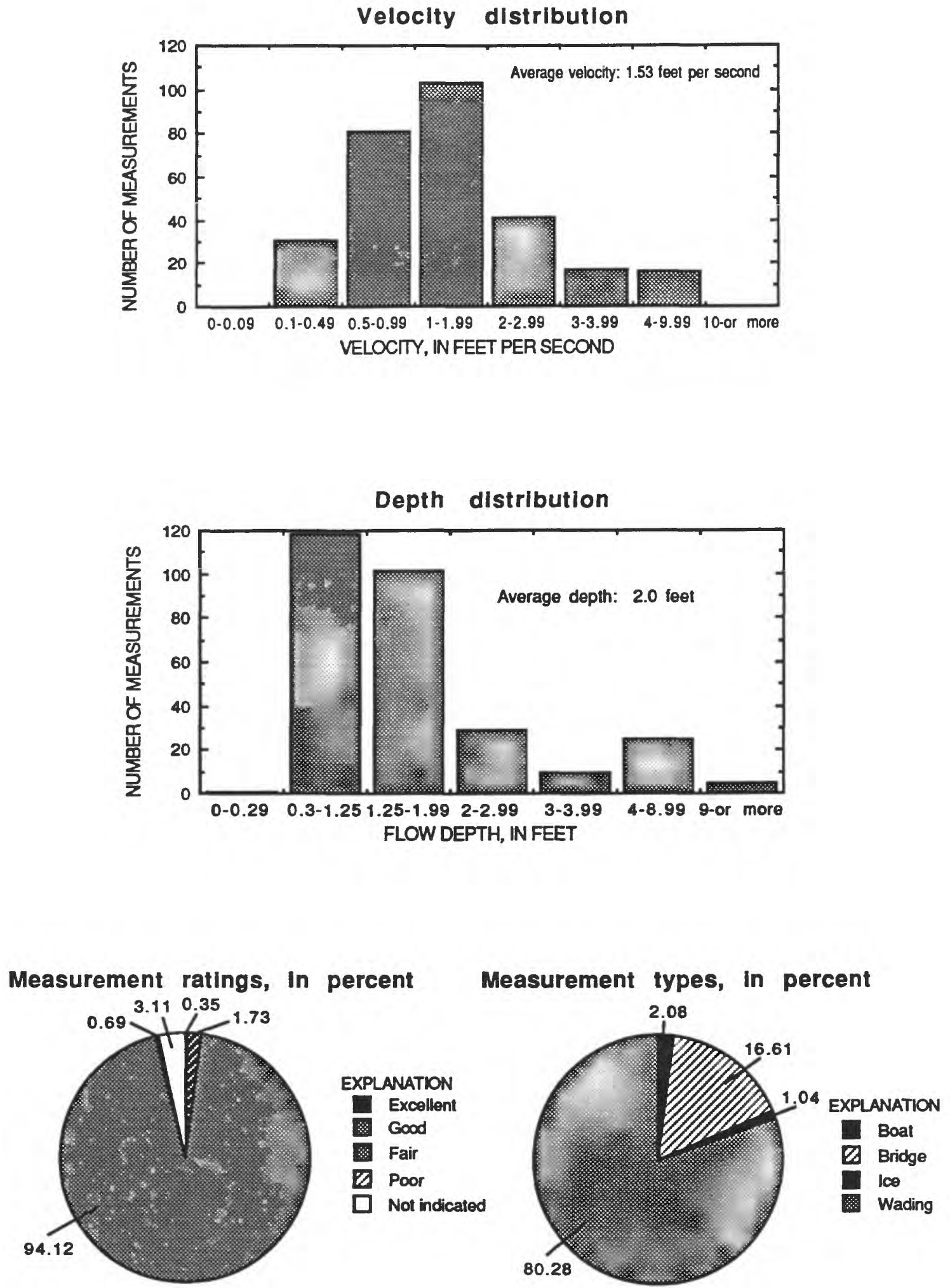

Figure 14.--Connecticut's velocity and depth frequency distributions and percentage of measurements by measurement rating and by measurement type for water year 1990 . 

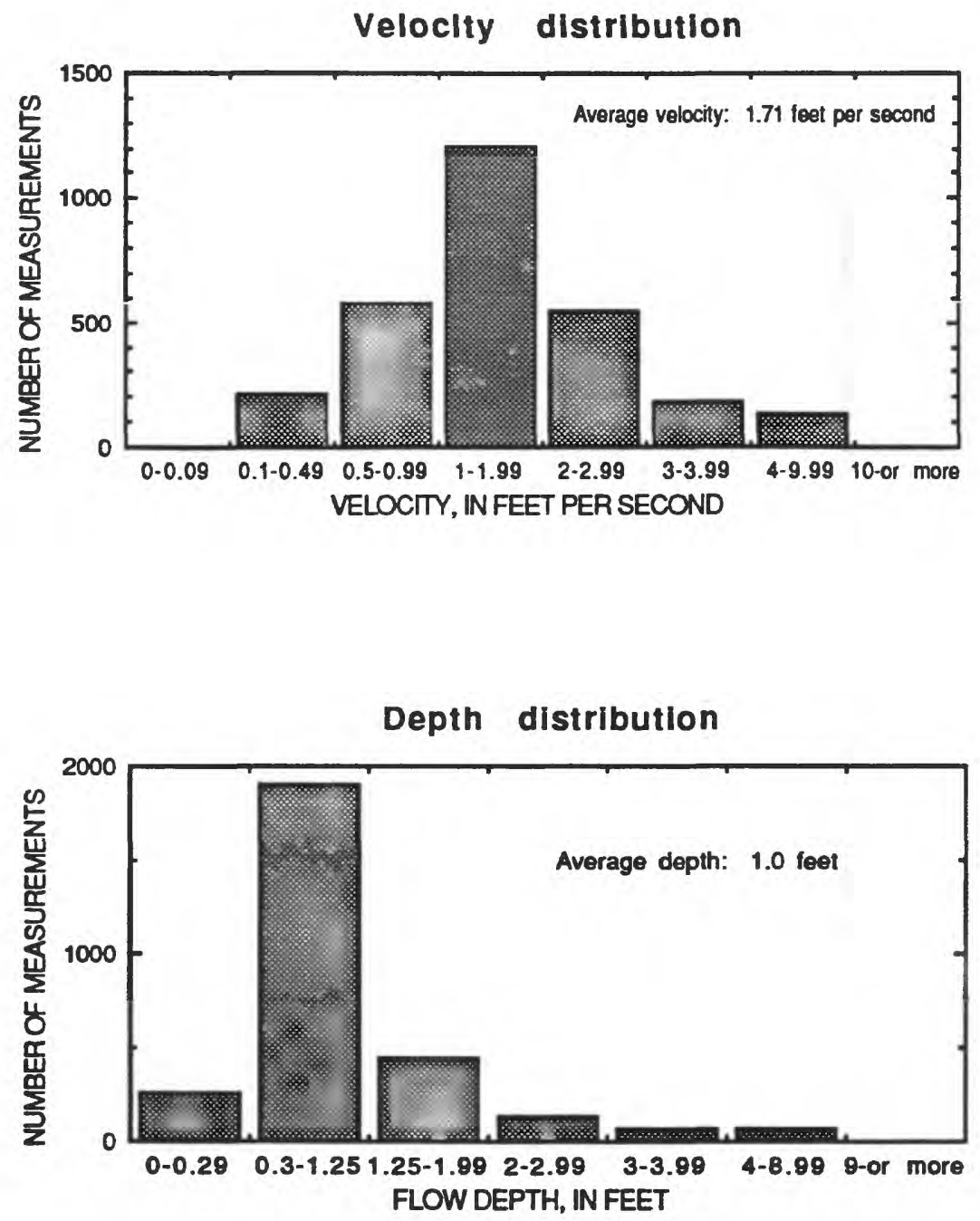

Measurement ratings, In percent
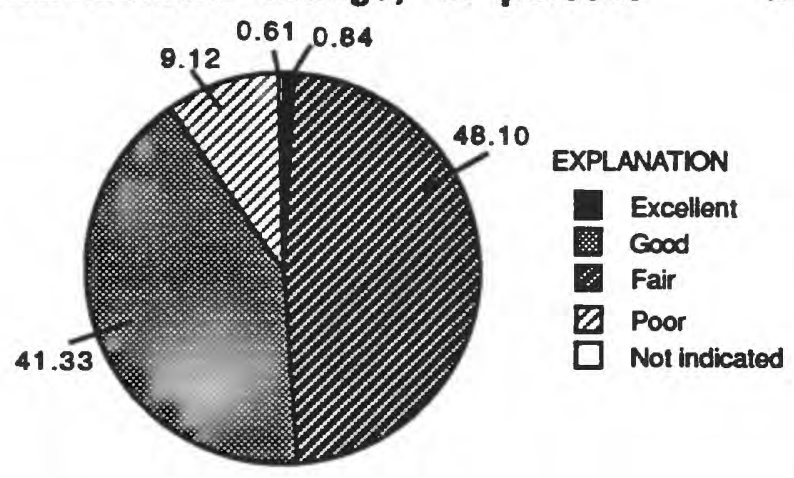

Measurement types, In percent

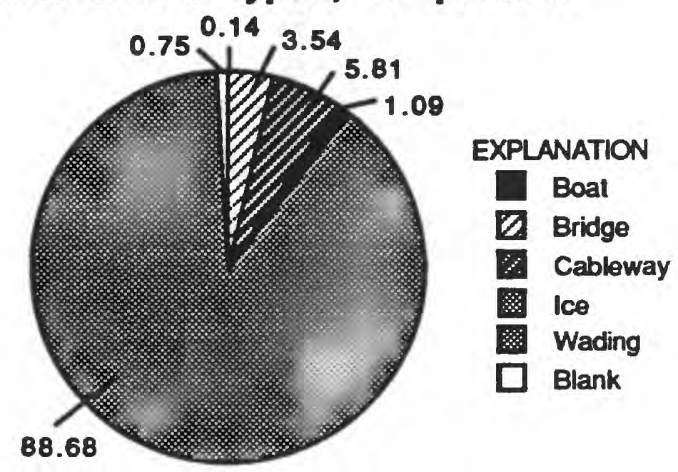

Figure 15.--Colorado's velocity and depth frequency distributions and percentage of measurements by measurement rating and by measurement type for water year 1990 . 

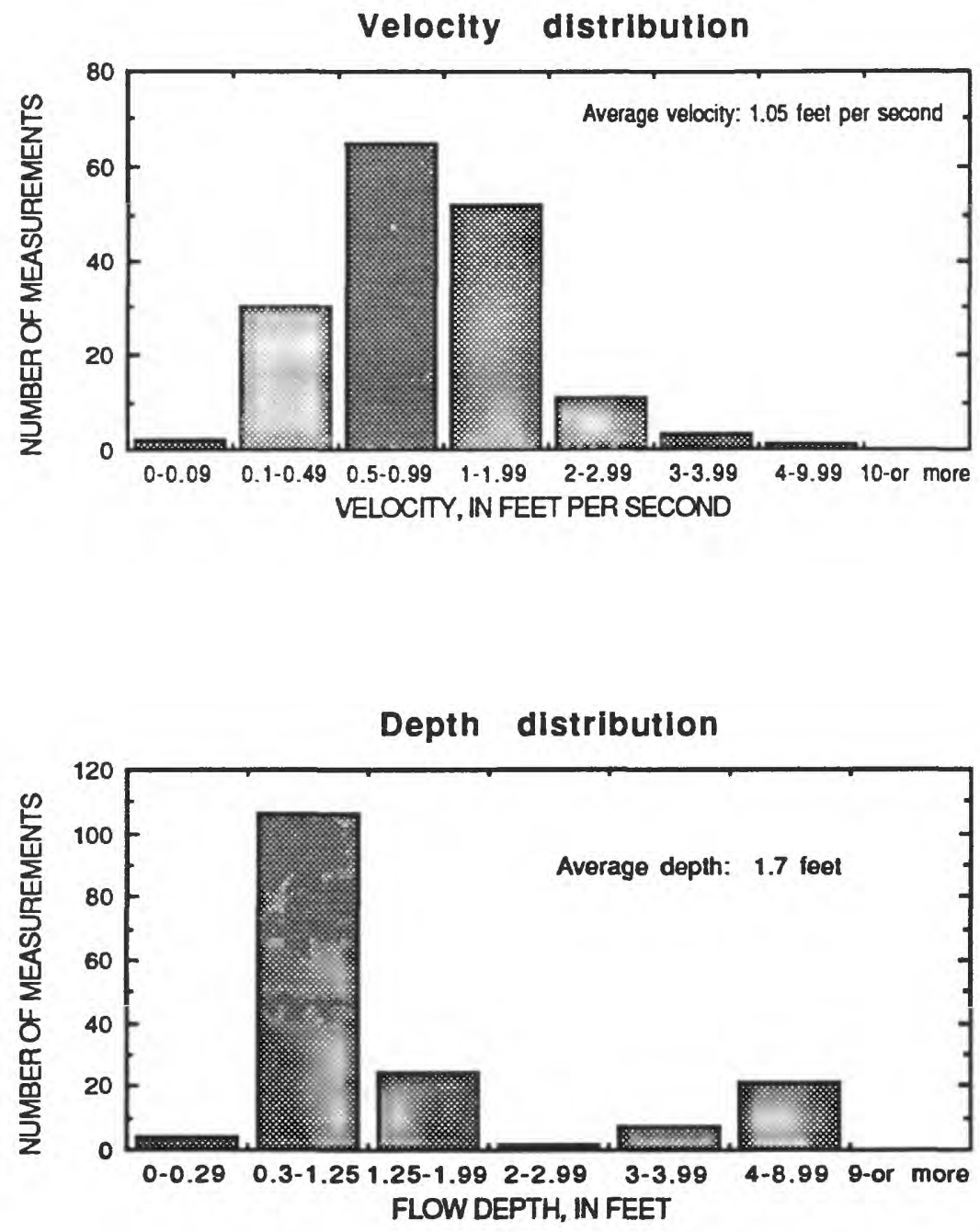

Measurement ratings, in percent

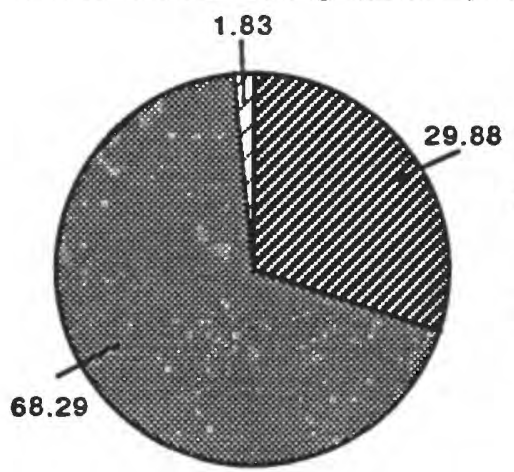

Measurement types, in percent

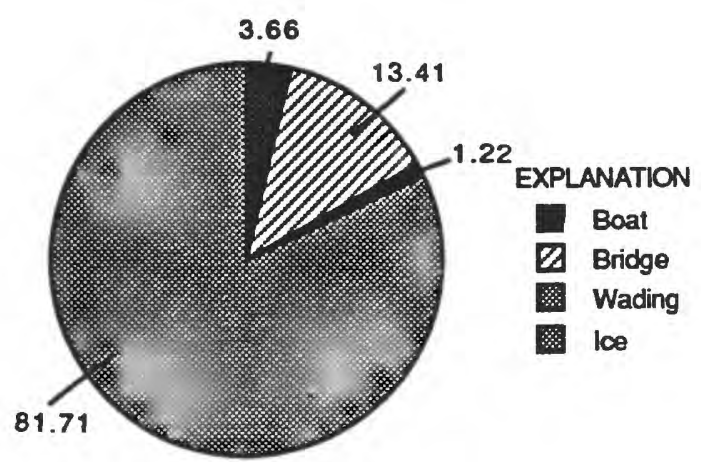

Figure 16.--Delaware's velocity and depth frequency distributions and percentage of measurements by measurement rating and by measurement type for water year 1990 . 

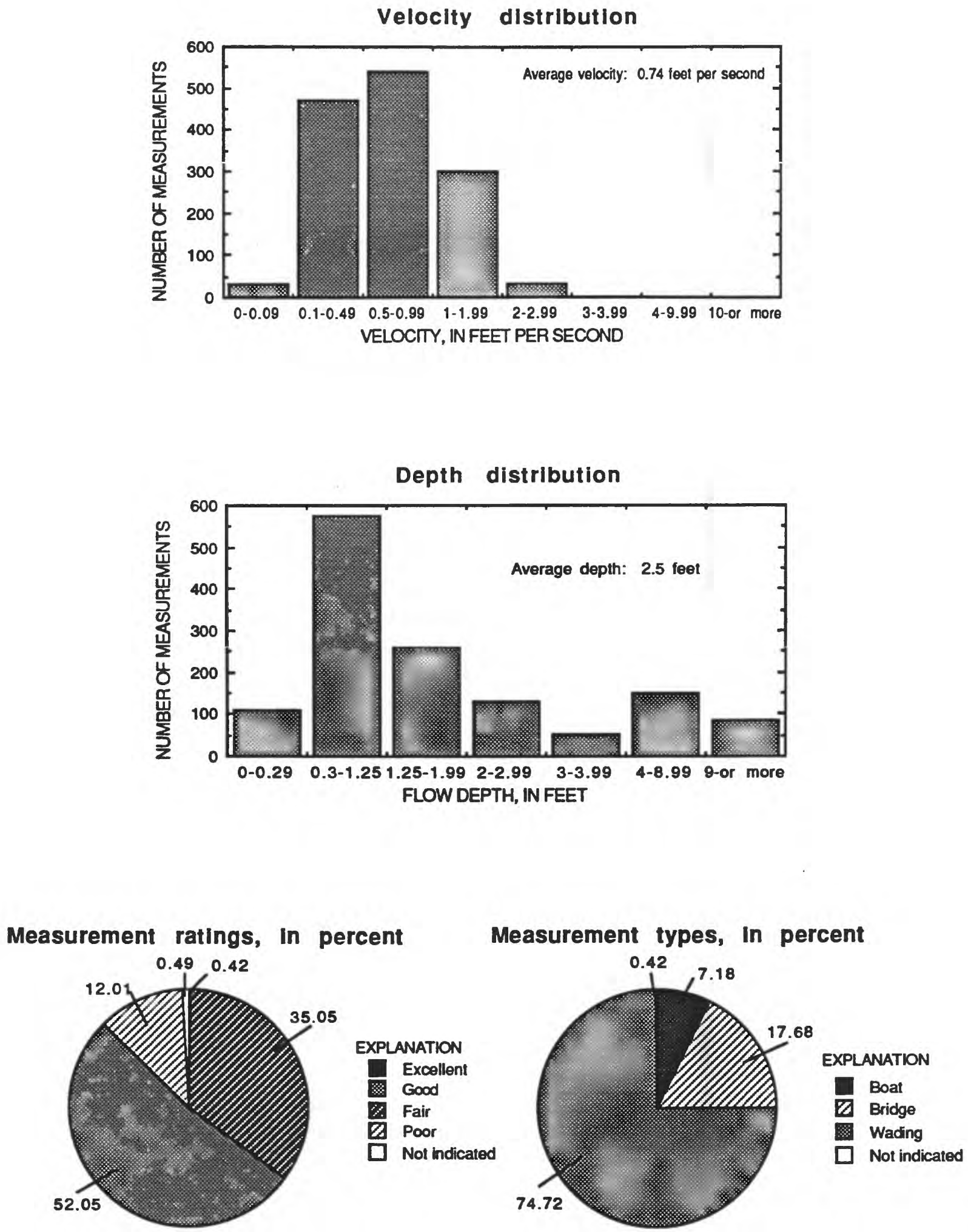

Figure 17.--Florida's velocity and depth frequency distributions and percentage of measurements by measurement rating and by measurement type for water year 1990 . 

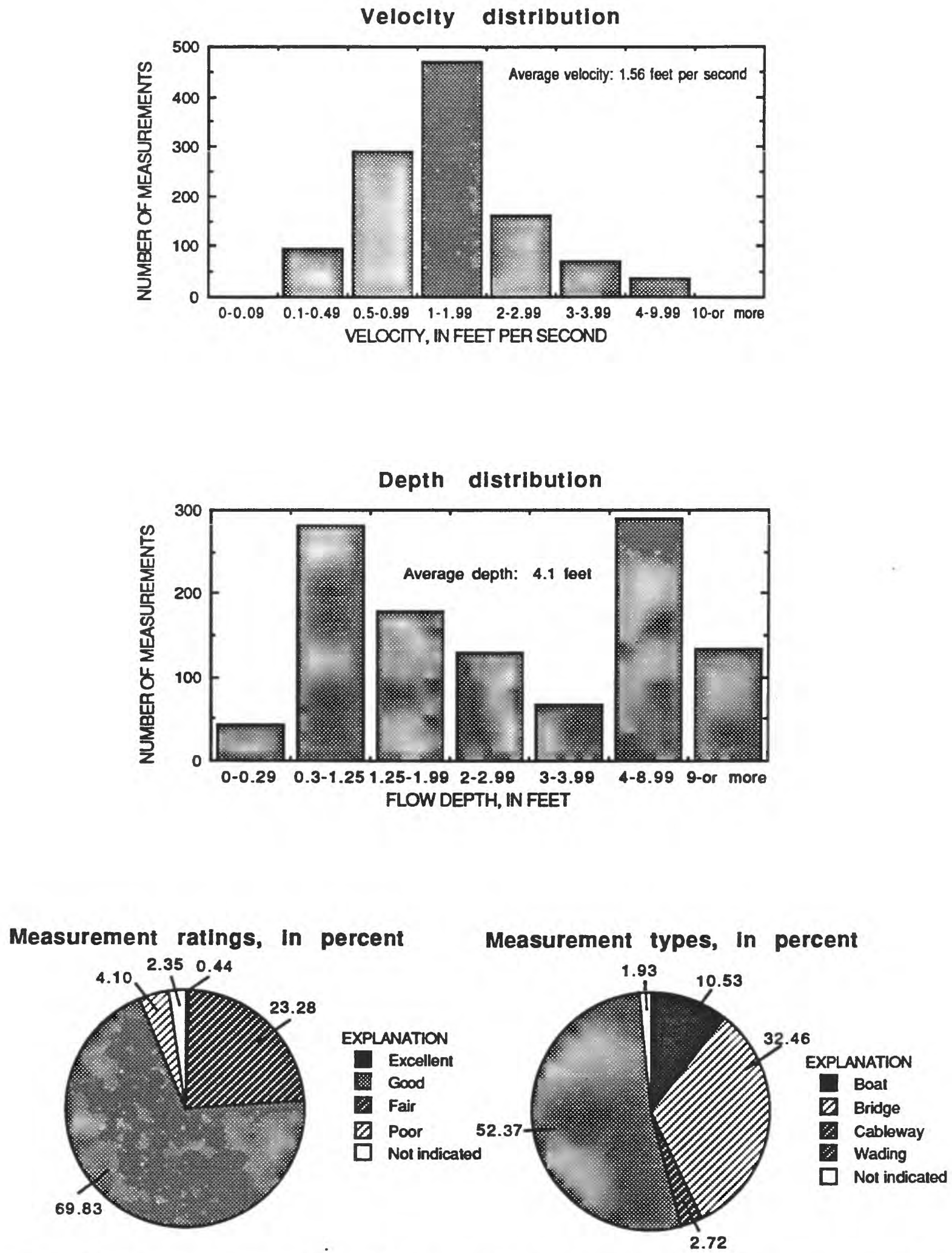

Figure 18.--Georgia's velocity and depth frequency distributions and percentage of measurements by measurement rating and by measurement type for water year 1990. 

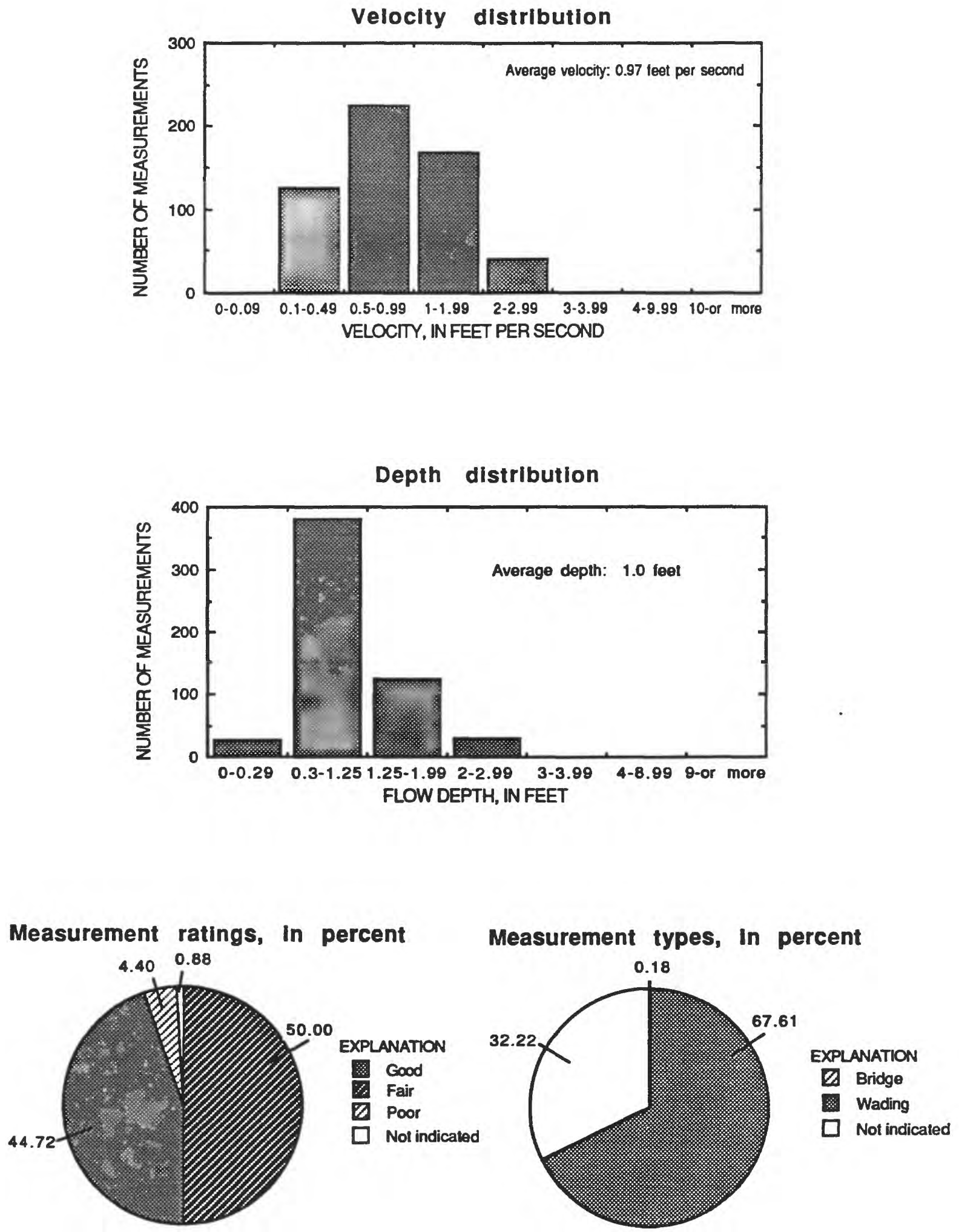

Figure 19.--Hawaii's velocity and depth frequency distributions and percentage of measurements by measurement rating and by measurement type for water year 1990 . 

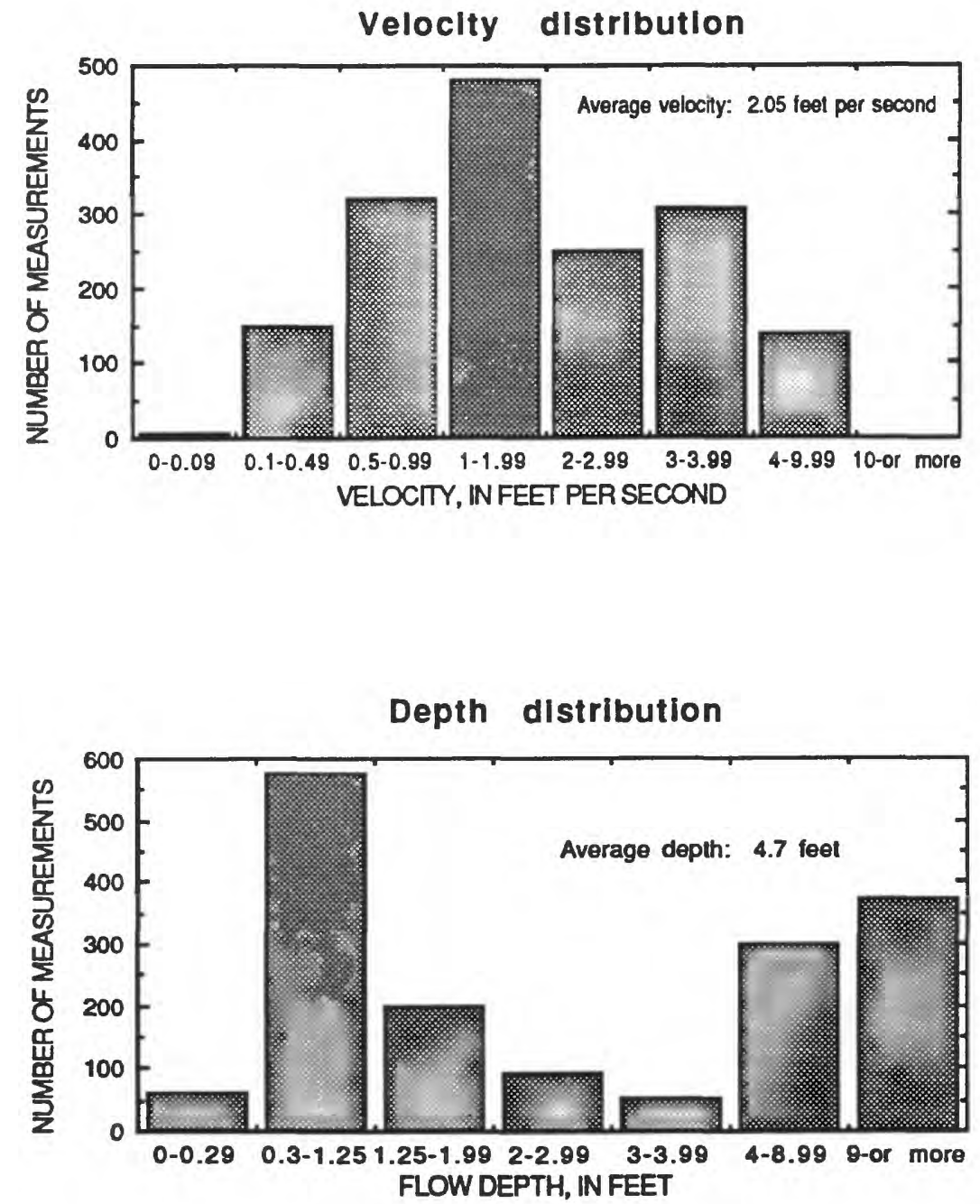

Measurement ratings, in percent

Measurement types, In percent
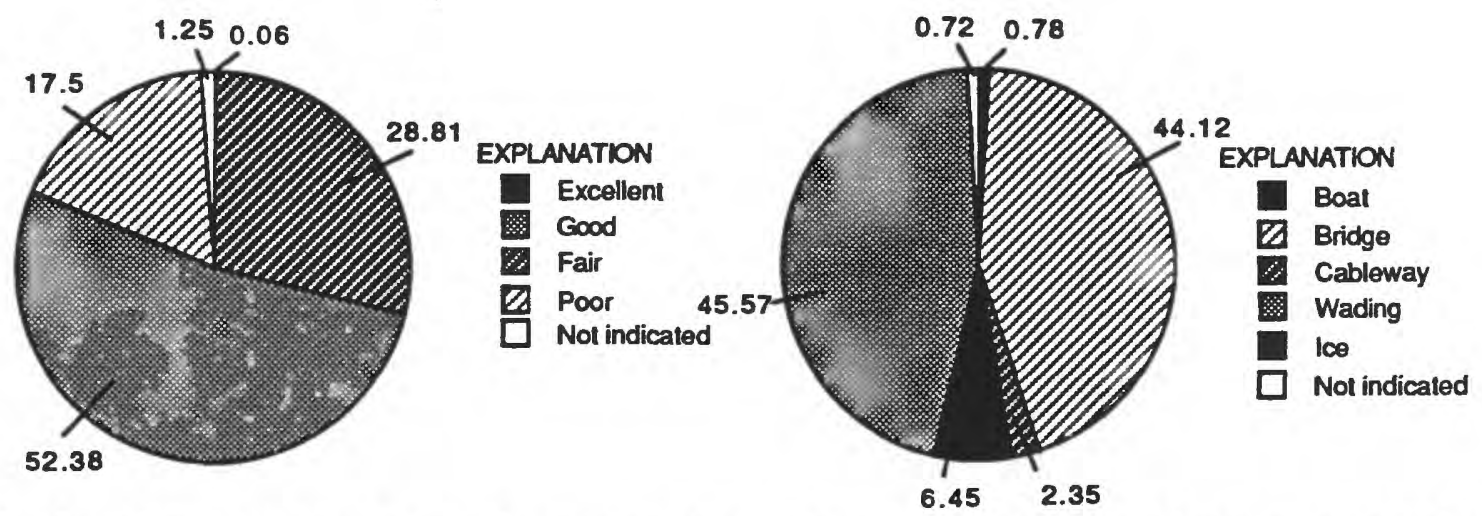

Figure 20.--Iowa's velocity and depth frequency distributions and percentage of measurements by measurement rating and by measurement type for water year 1990. 

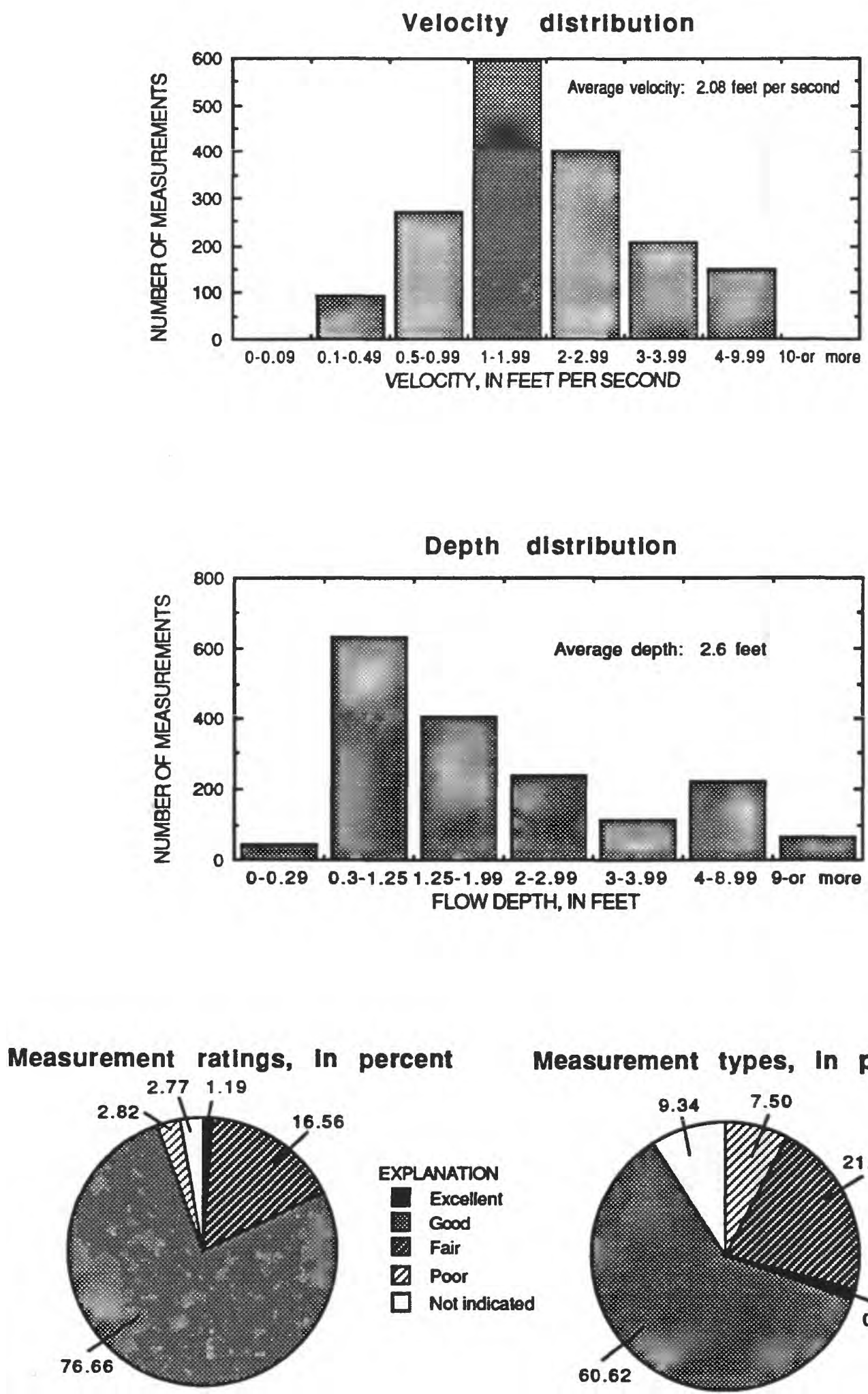

percent

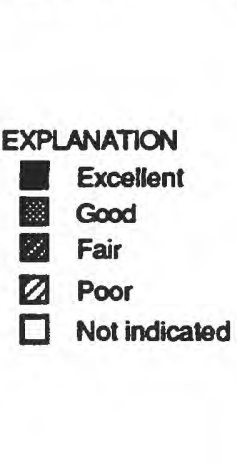

Measurement types, In percent

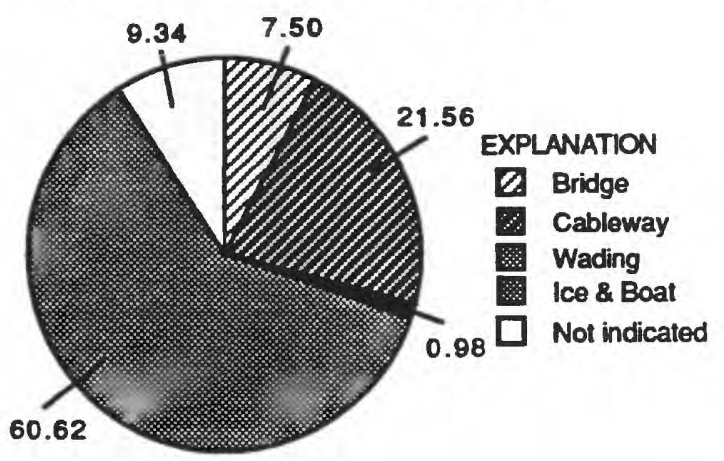

Figure 21.--Idaho's velocity and depth frequency distributions and percentage of measurements by measurement rating and by measurement type for water year 1990 . 

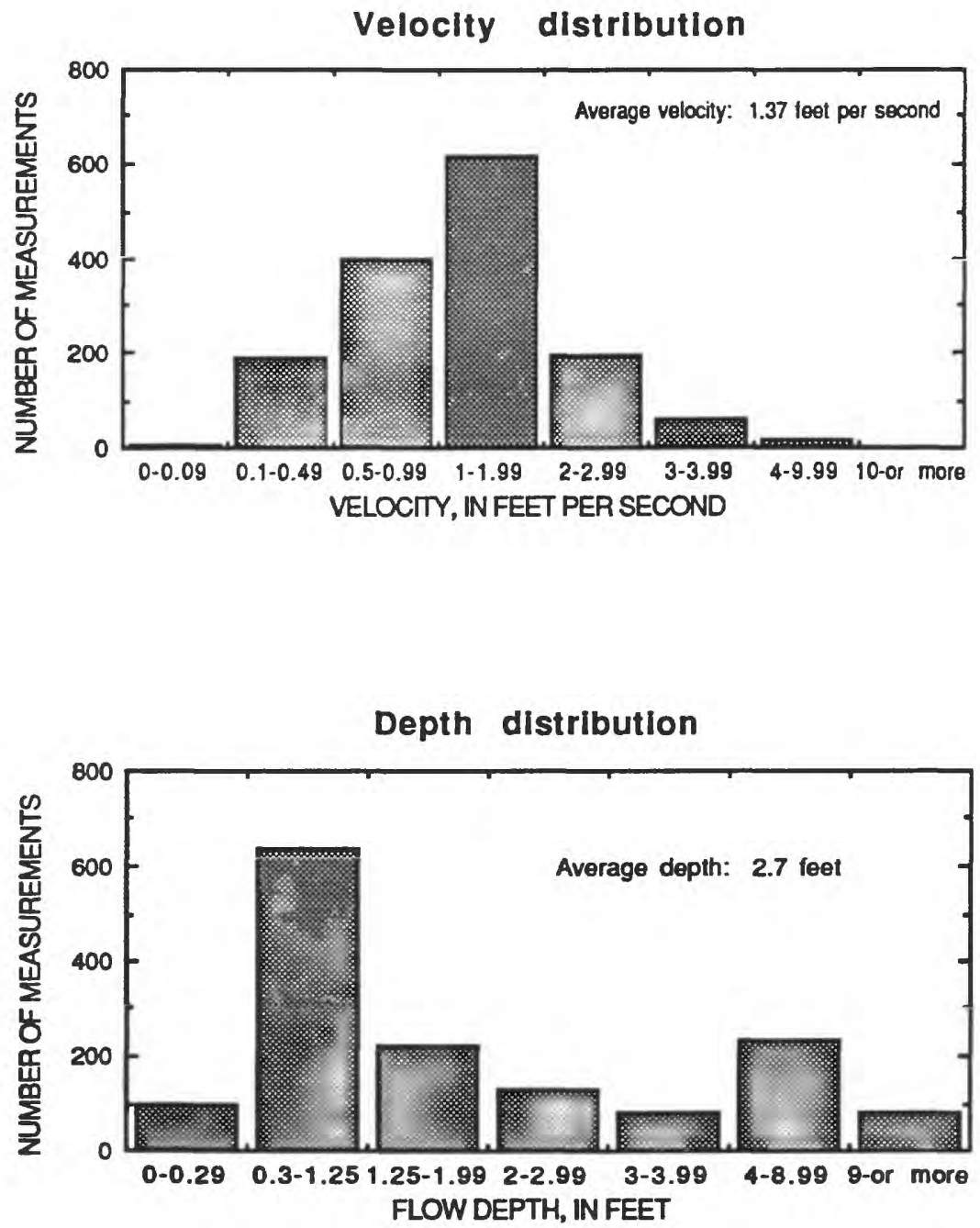

Measurement ratings, In percent

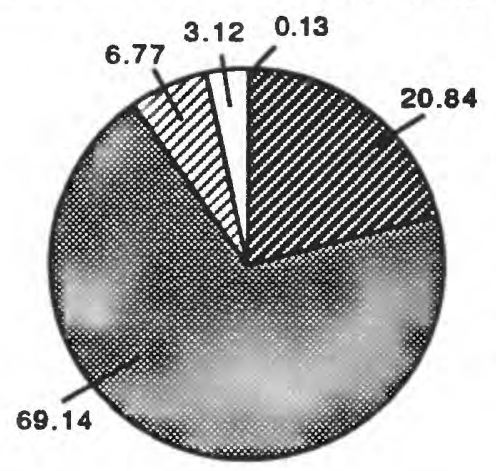

Measurement types, in percent

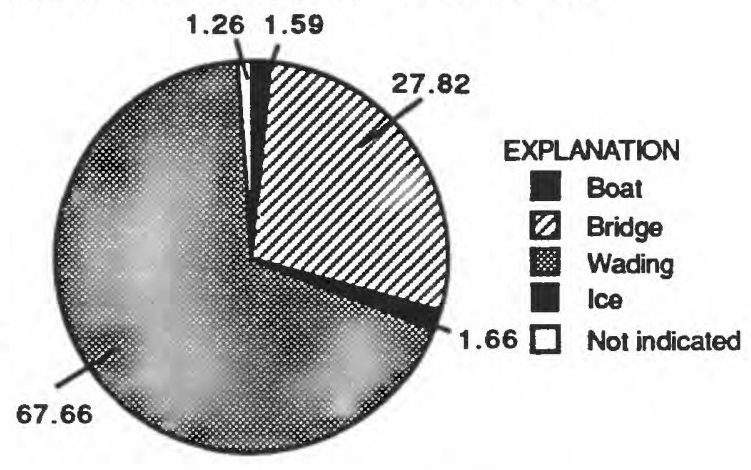

Figure 22.--Illinois's velocity and depth frequency distributions and percentage of measurements by measurement rating and by measurement type for water year 1990 . 

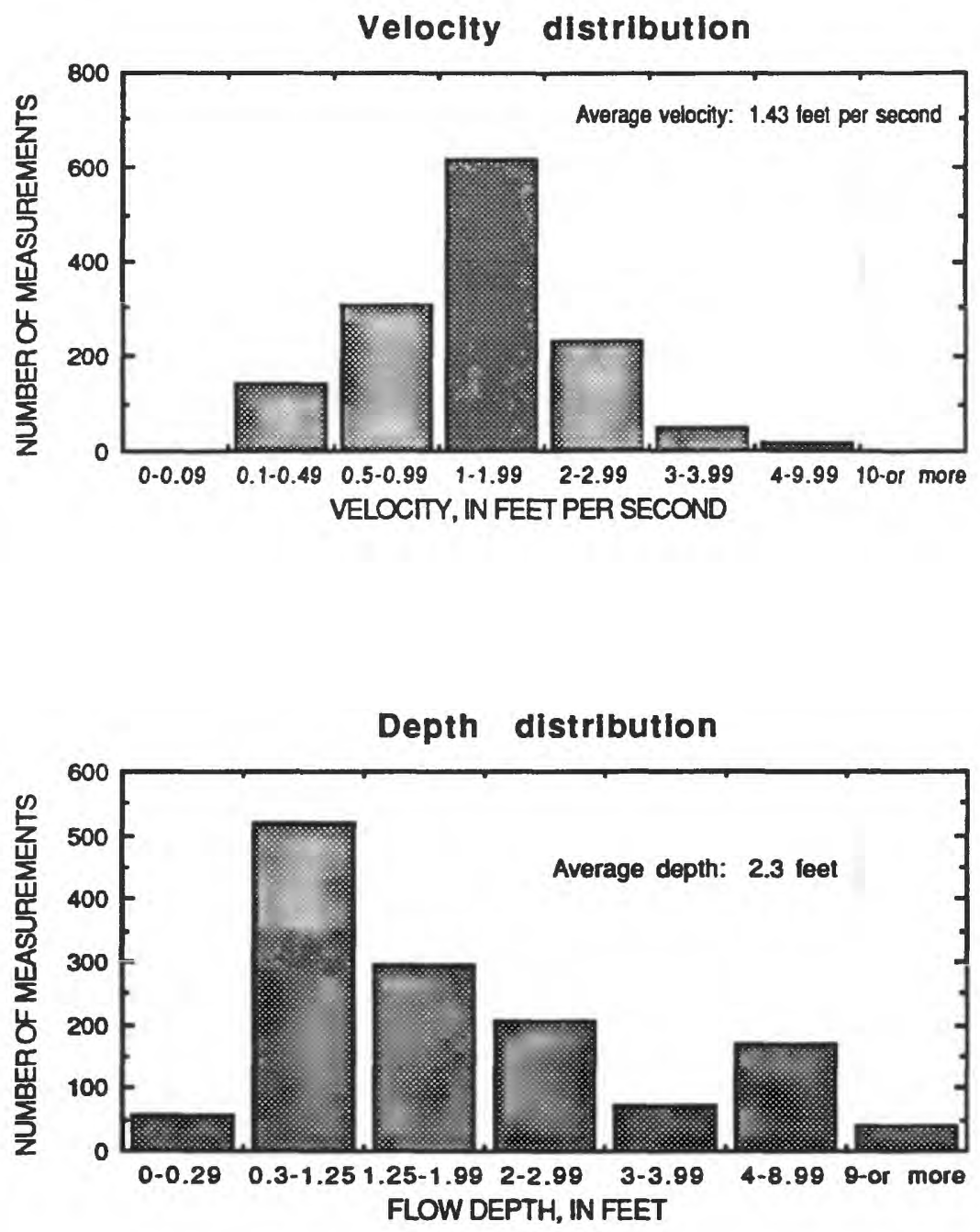

Measurement ratings, In percent

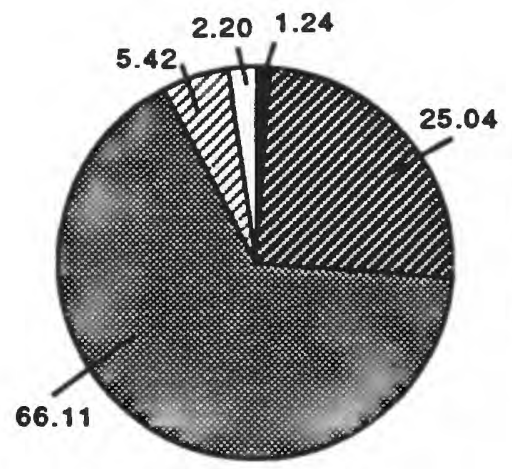

Measurement types, In percent

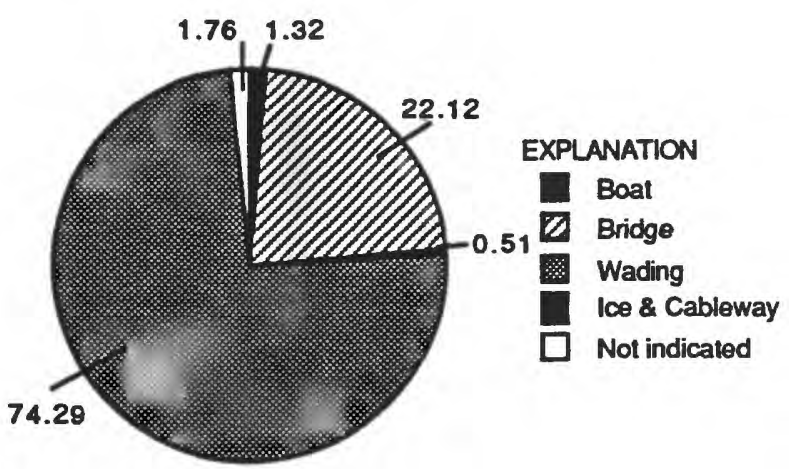

Figure 23.--Indiana's velocity and depth frequency distributions and percentage of measurements by measurement rating and by measurement type for water year 1990 . 

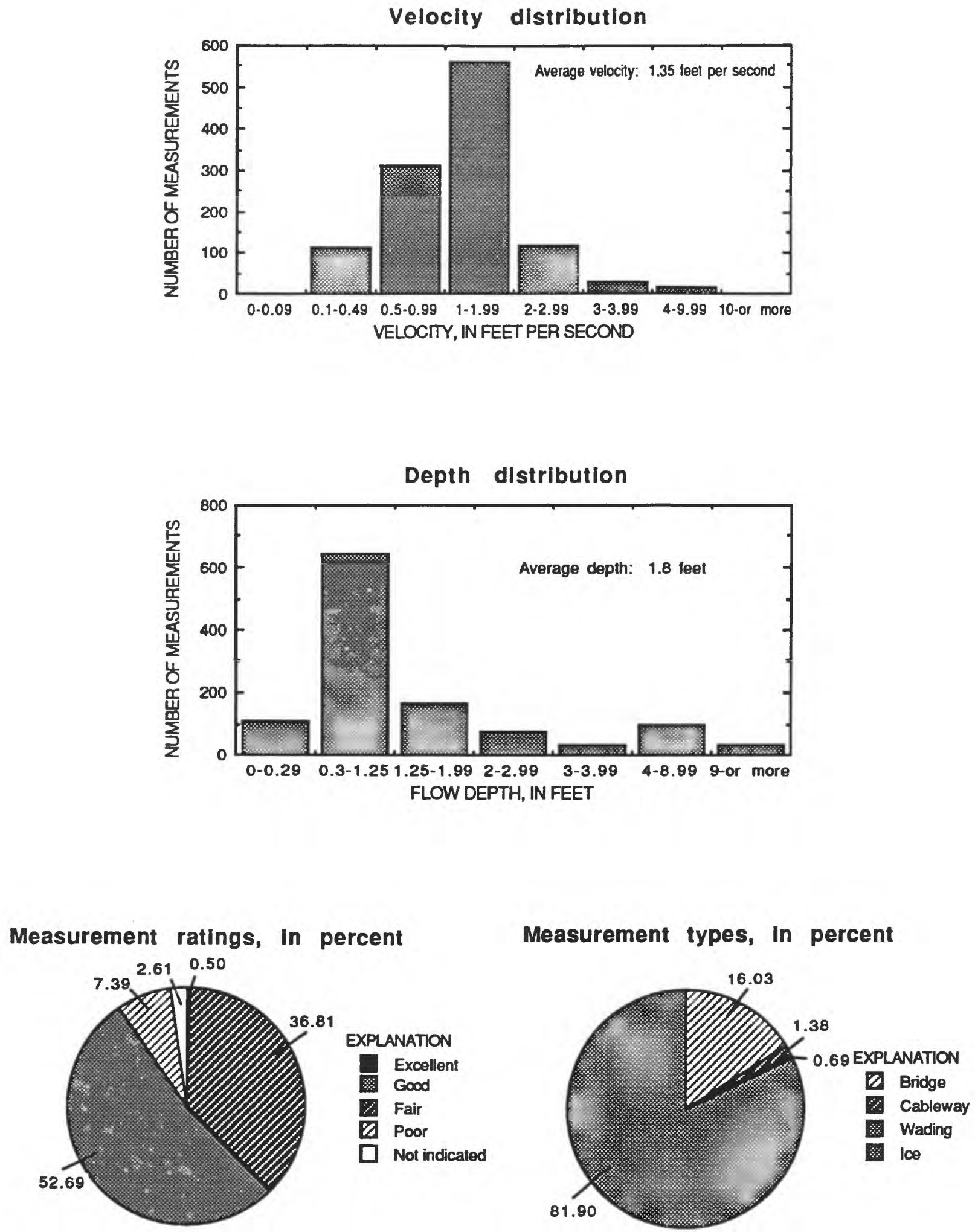

Figure 24.--Kansas's velocity and depth frequency distributions and percentage of measurements by measurement rating and by measurement type for water year 1990 . 

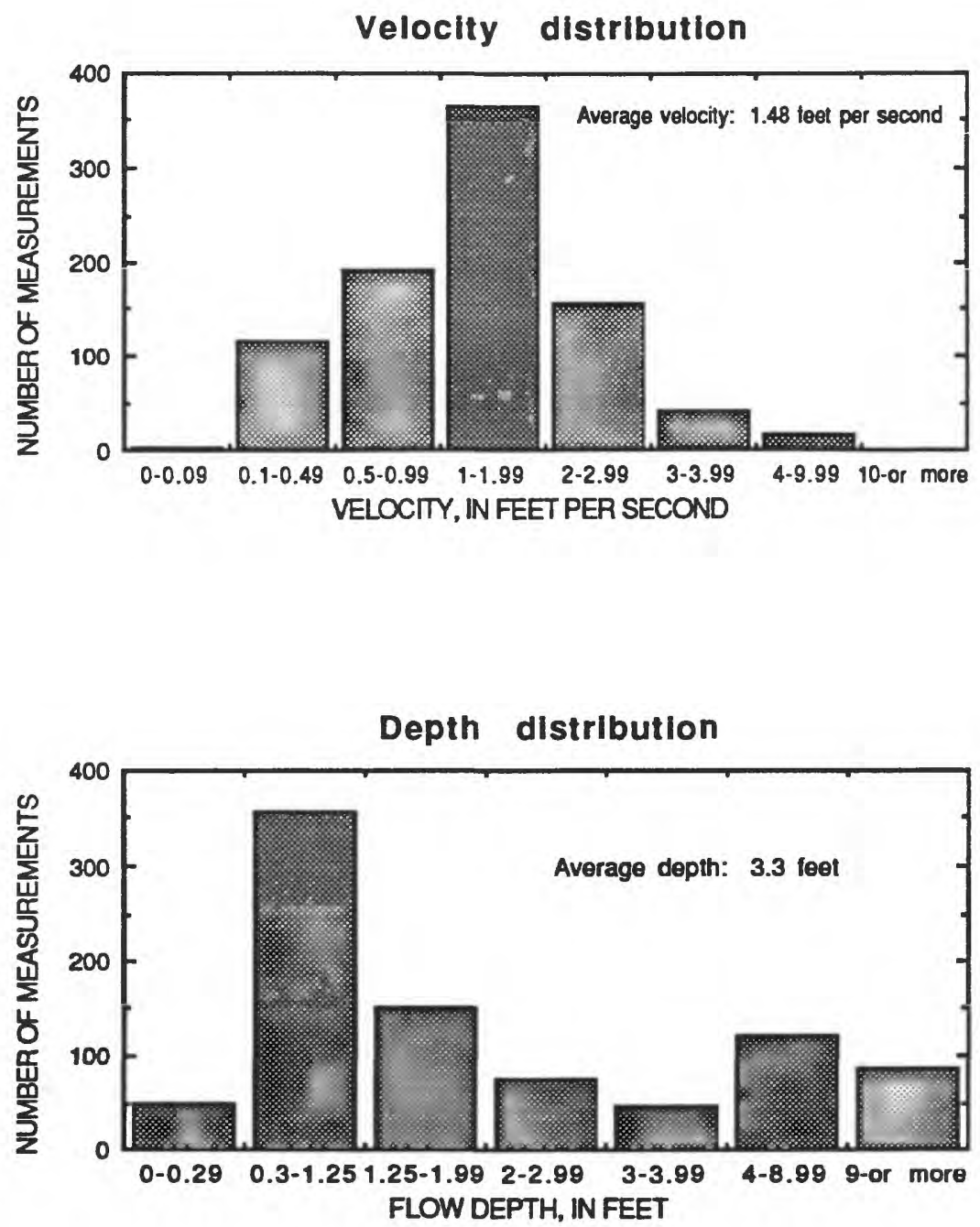

Measurement ratings, In percent

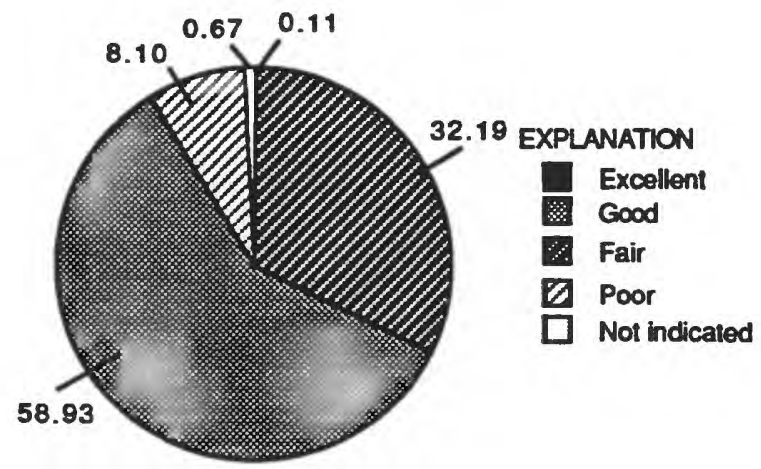

Measurement types, In percent

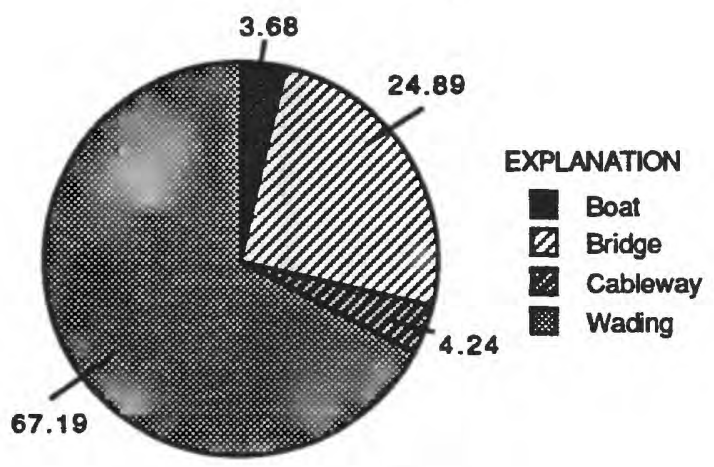

Figure 25.--Kentucky's velocity and depth frequency distributions and percentage of measurements by measurement rating and by measurement type for water year 1990 . 

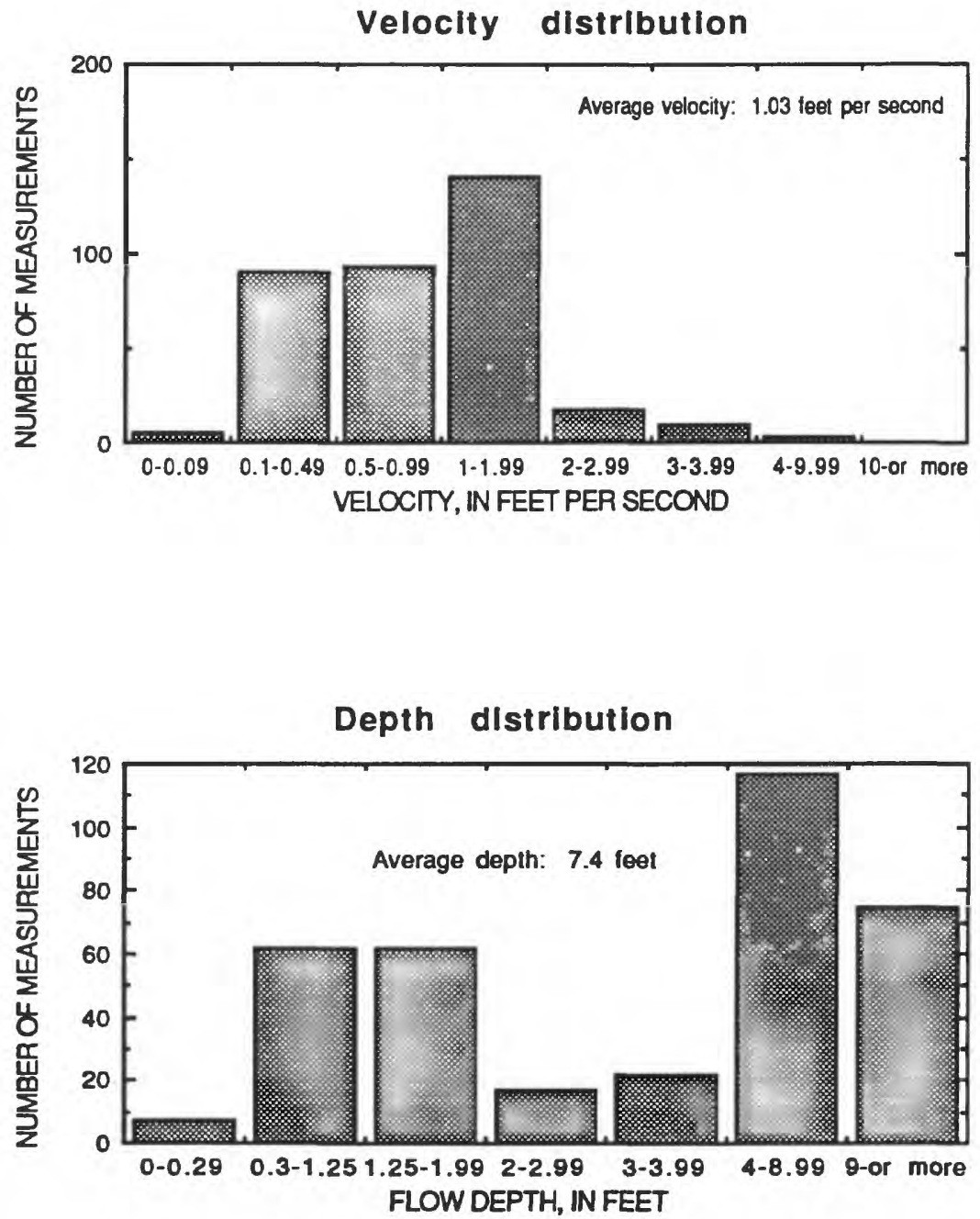

Measurement ratings, in percent

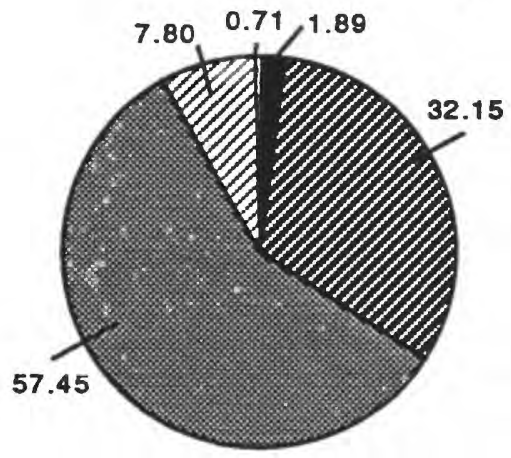

Measurement types, in percent

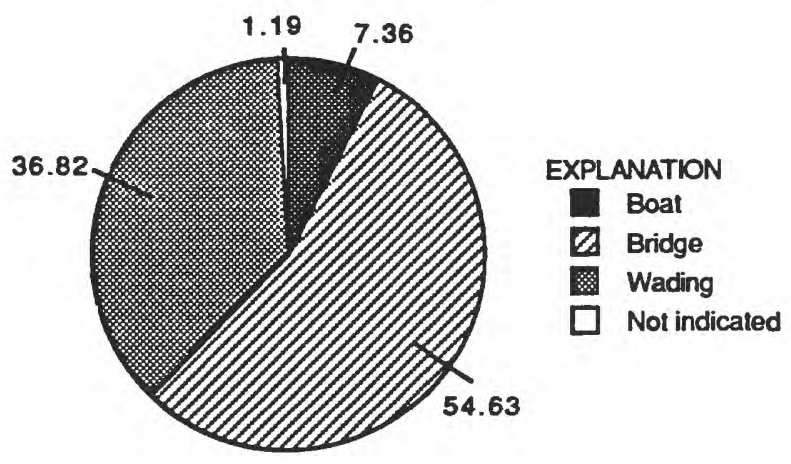

Figure 26.--Louisiana's velocity and depth frequency distributions and percentage of measurements by measurement rating and by measurement type for water year 1990 . 

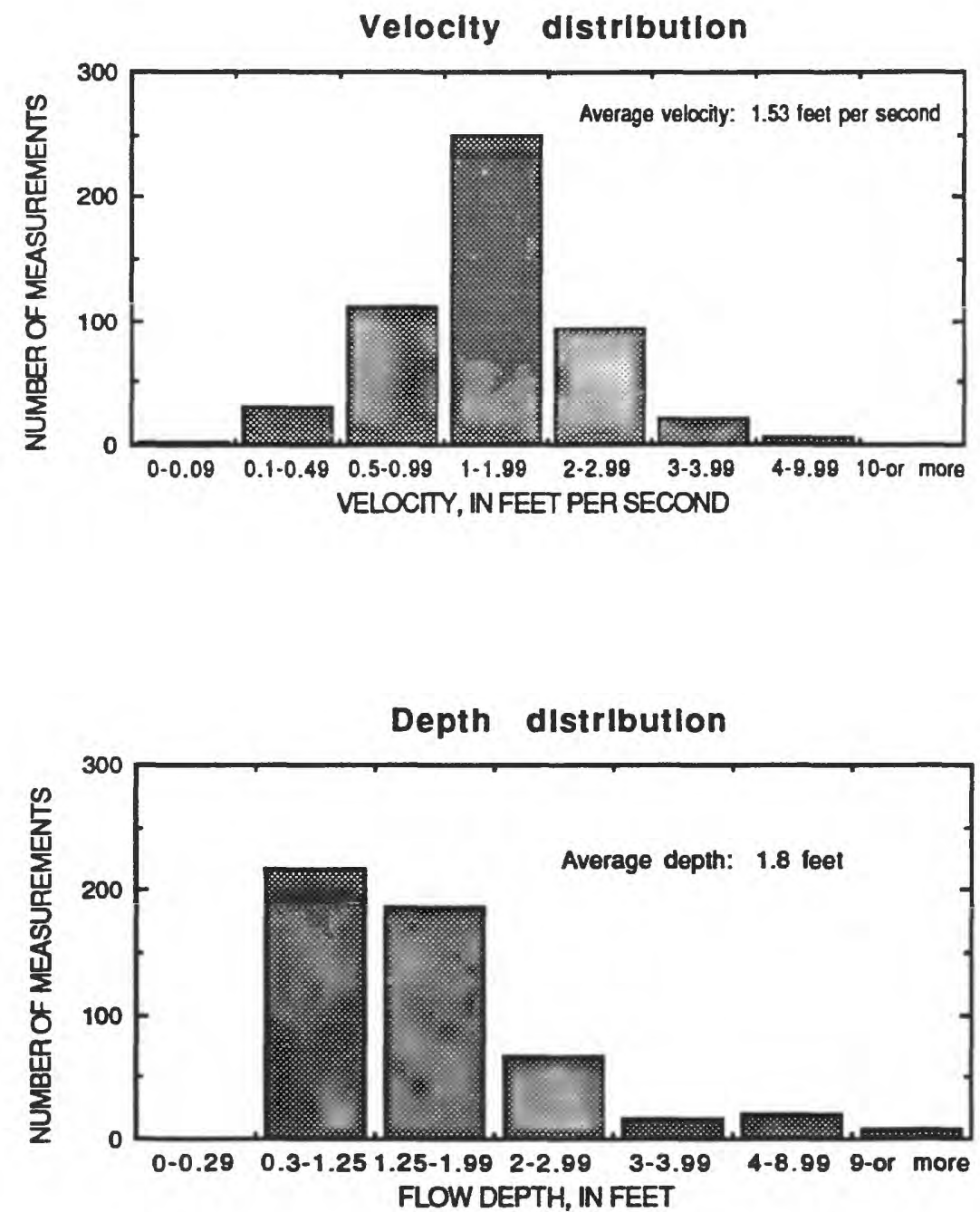

Measurement ratings, in percent

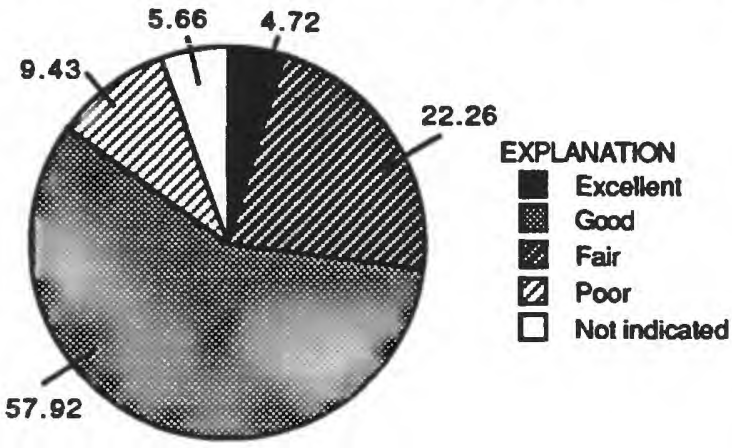

Measurement types, In percent

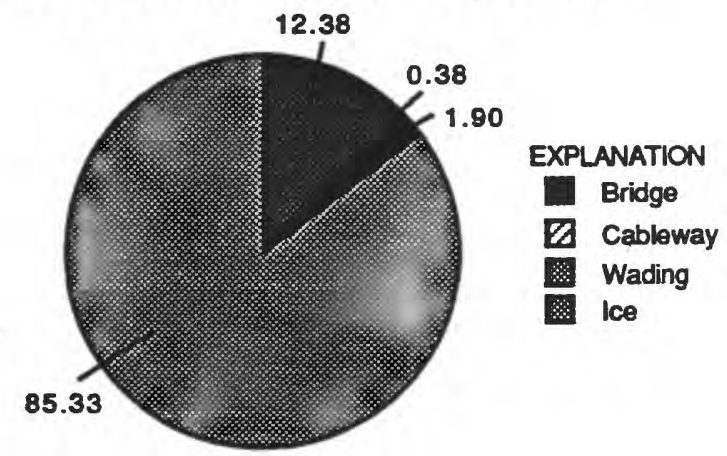

Figure 27.--Massachusetts's and Rhode Island's velocity and depth frequency distributions and percentage of measurements by measurement rating and by measurement type for water year 1990 . 

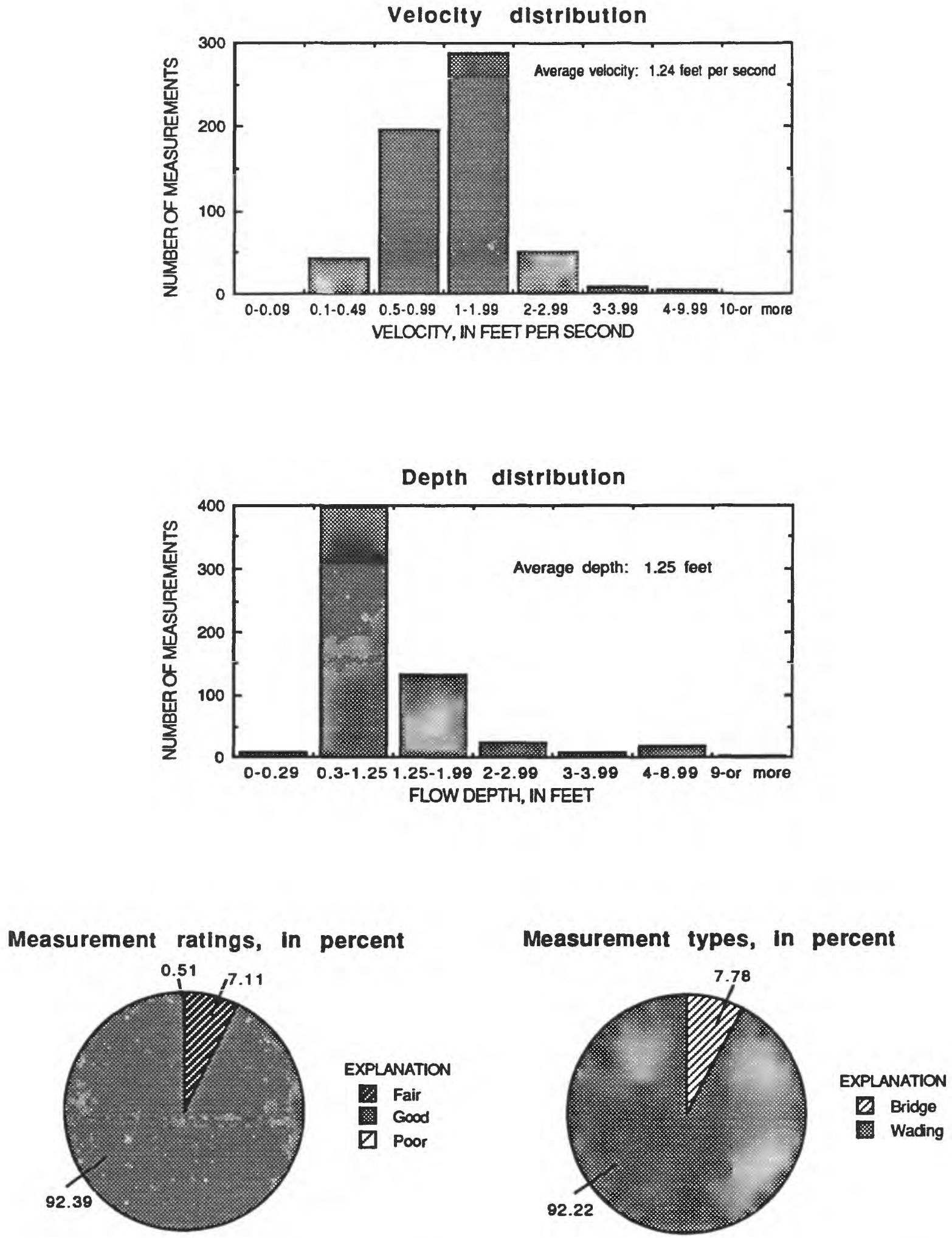

Figure 28.--Maryland's velocity and depth frequency distributions and percentage of measurements by measurement rating and by measurement type for water year 1990 . 

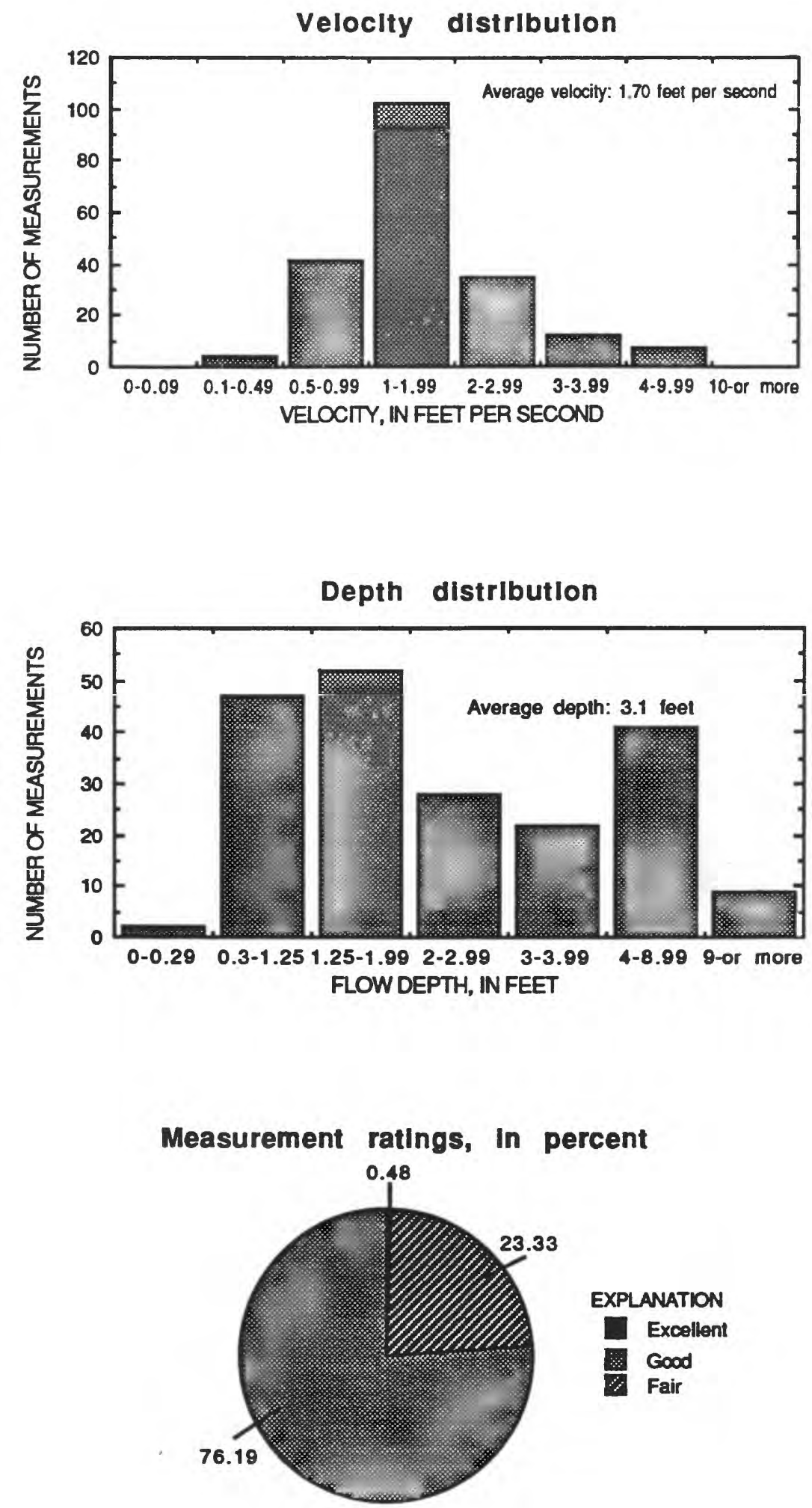

Figure 29.--Maine's velocity and depth frequency distributions and percentage of measurements by measurement rating for water year 1990. 

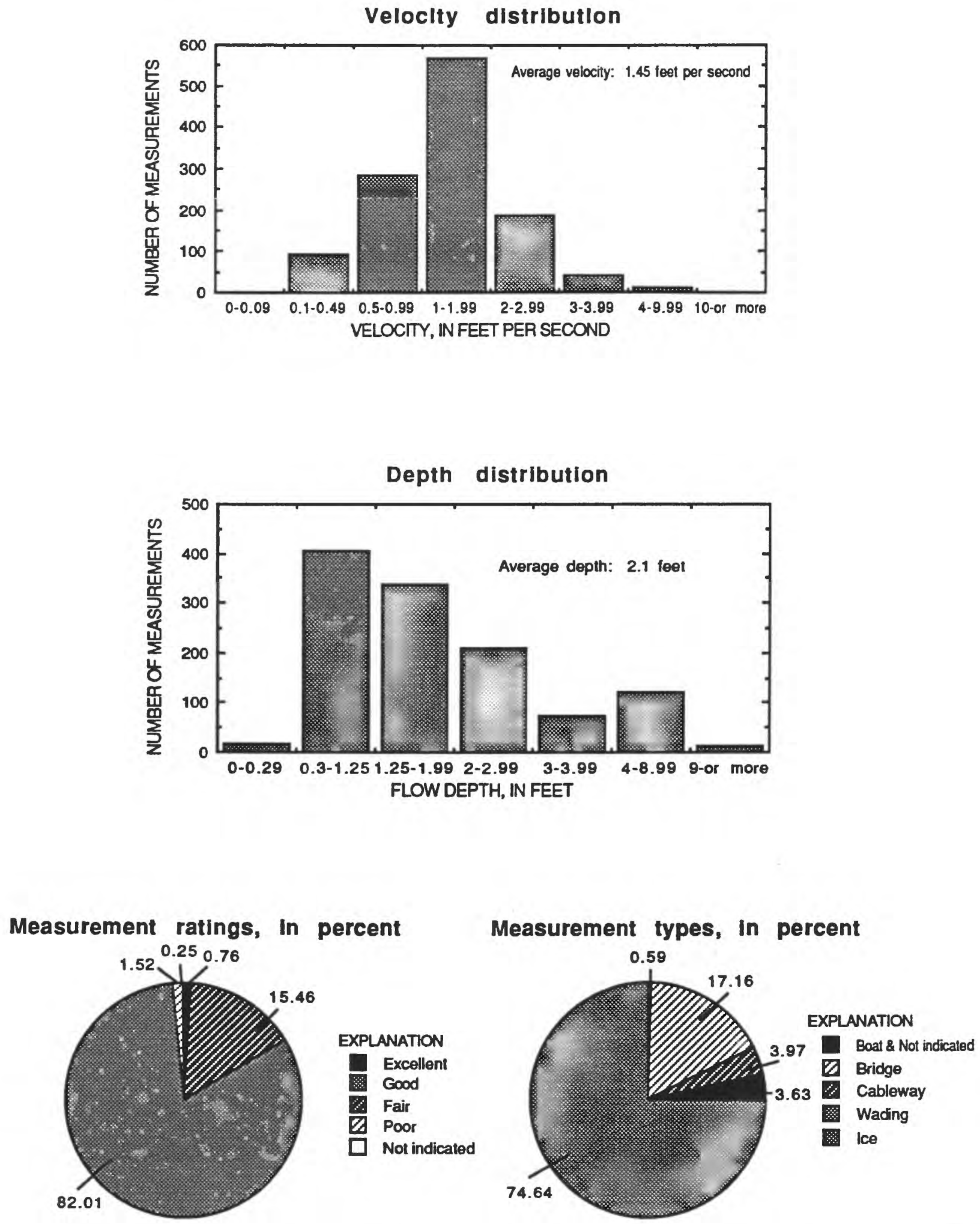

Figure 30.--Michigan's velocity and depth frequency distributions and percentage of measurements by measurement rating and by measurement type for water year 1990 . 

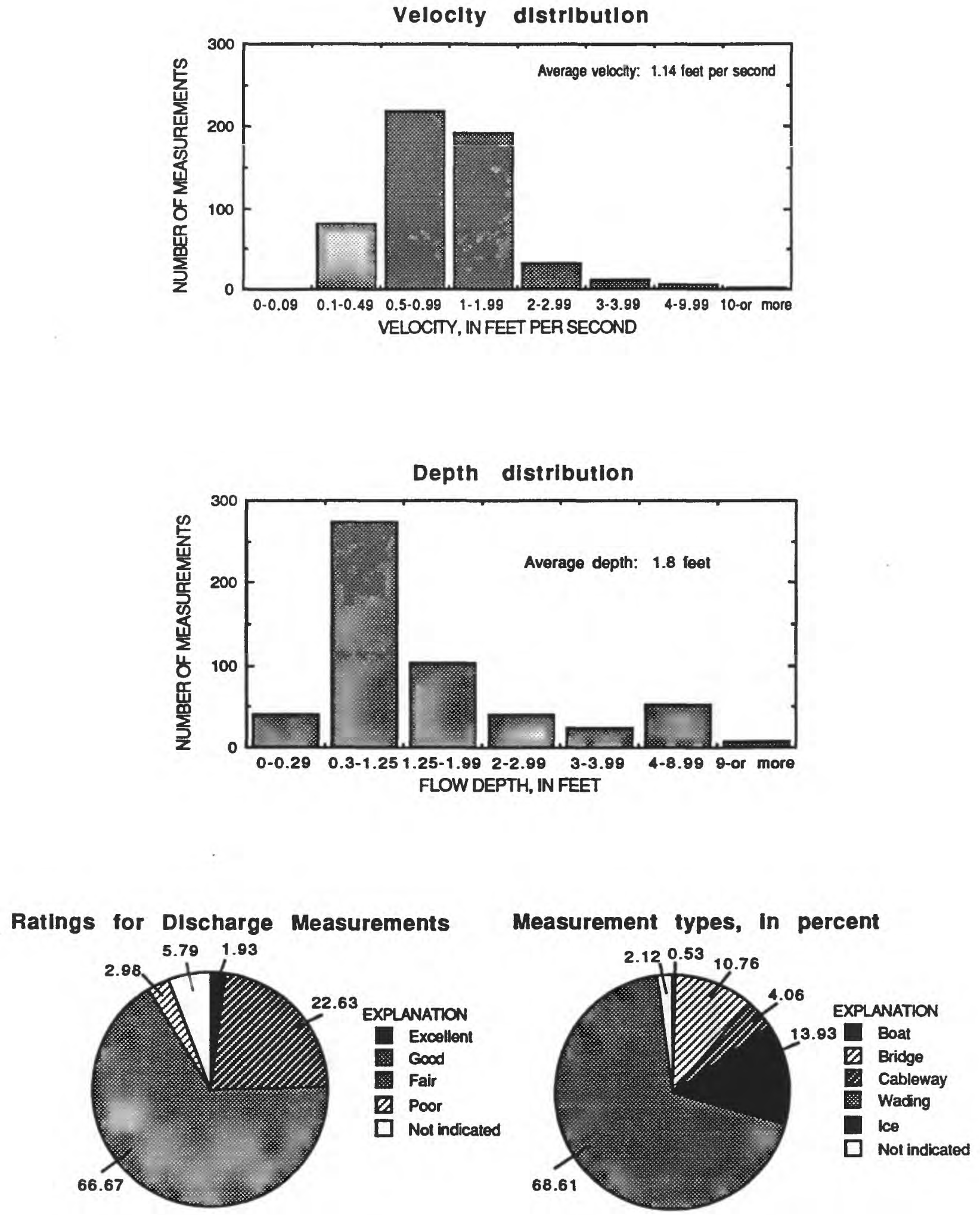

Figure 31.--Minnesota's velocity and depth frequency distributions and percentage of measurements by measurement rating and by measurement type for water year 1990 . 

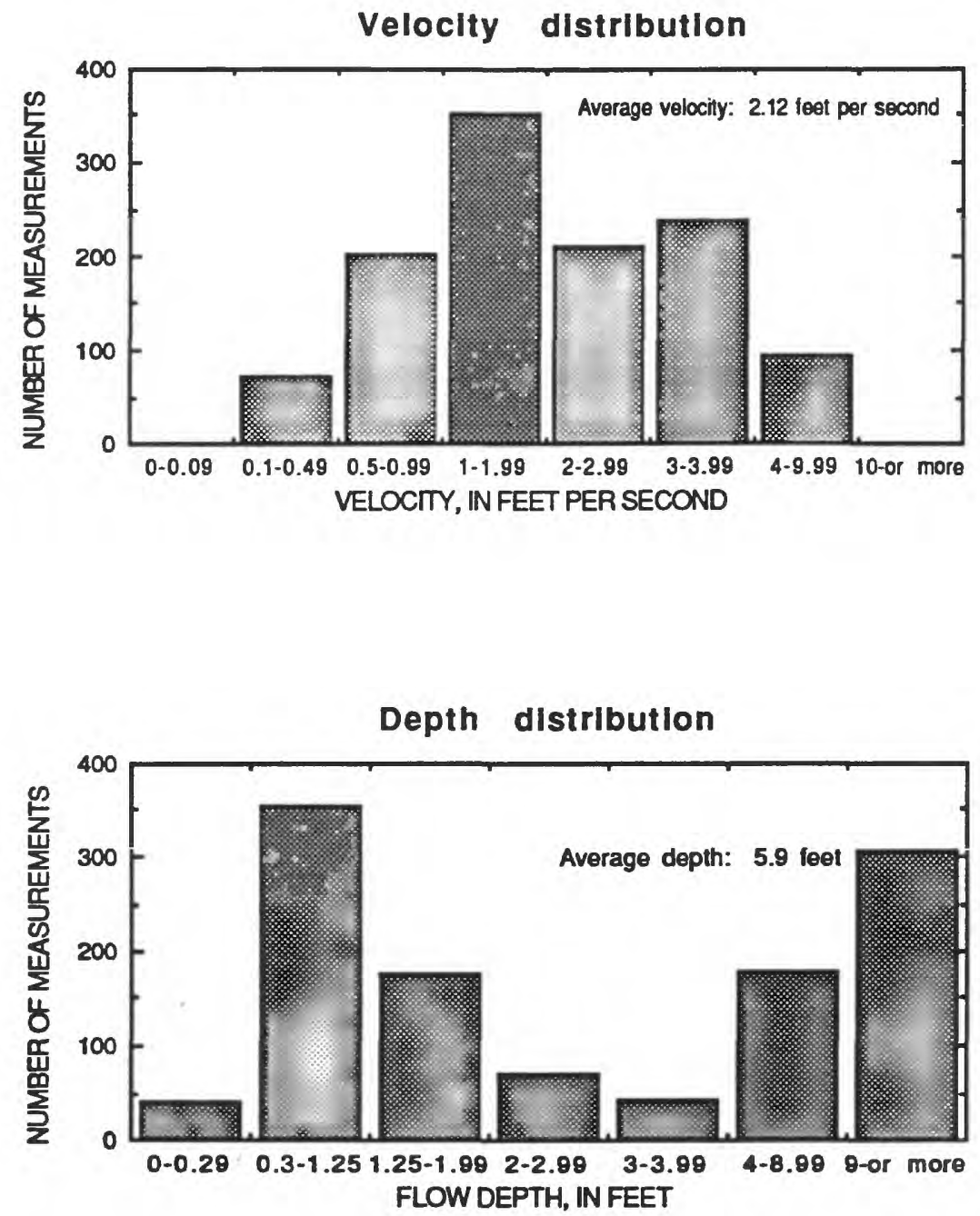

Measurement ratings, in percent

Measurement types, In percent
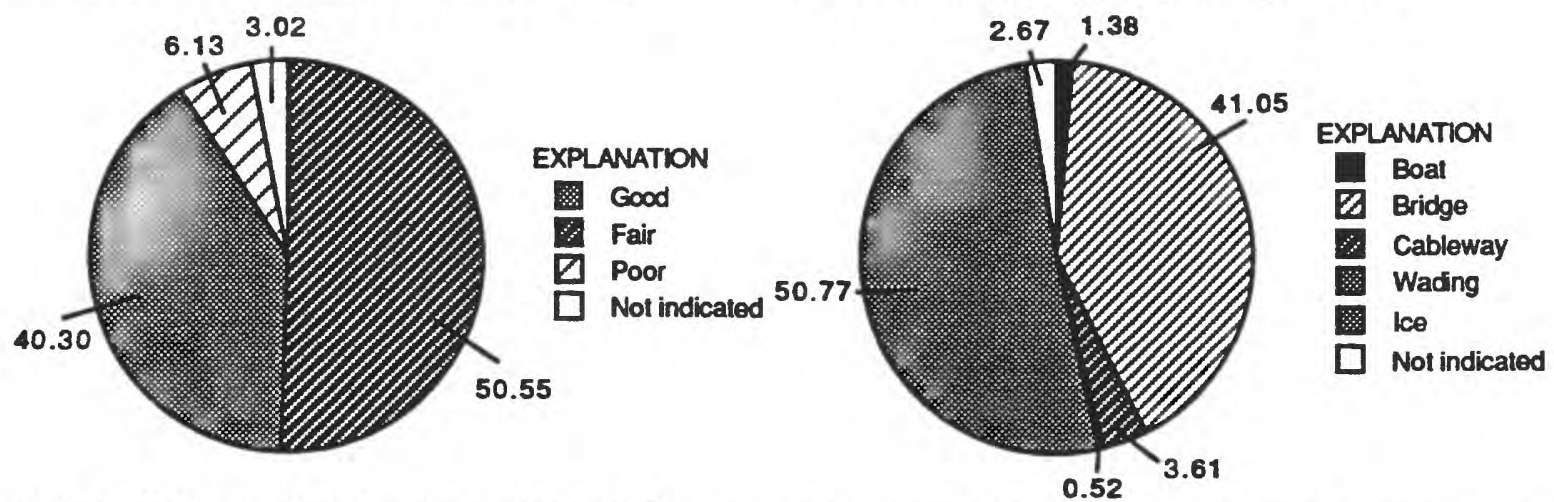

Figure 32.--Missouri's velocity and depth frequency distributions and percentage of measurements by measurement rating and by measurement type for water year 1990 . 

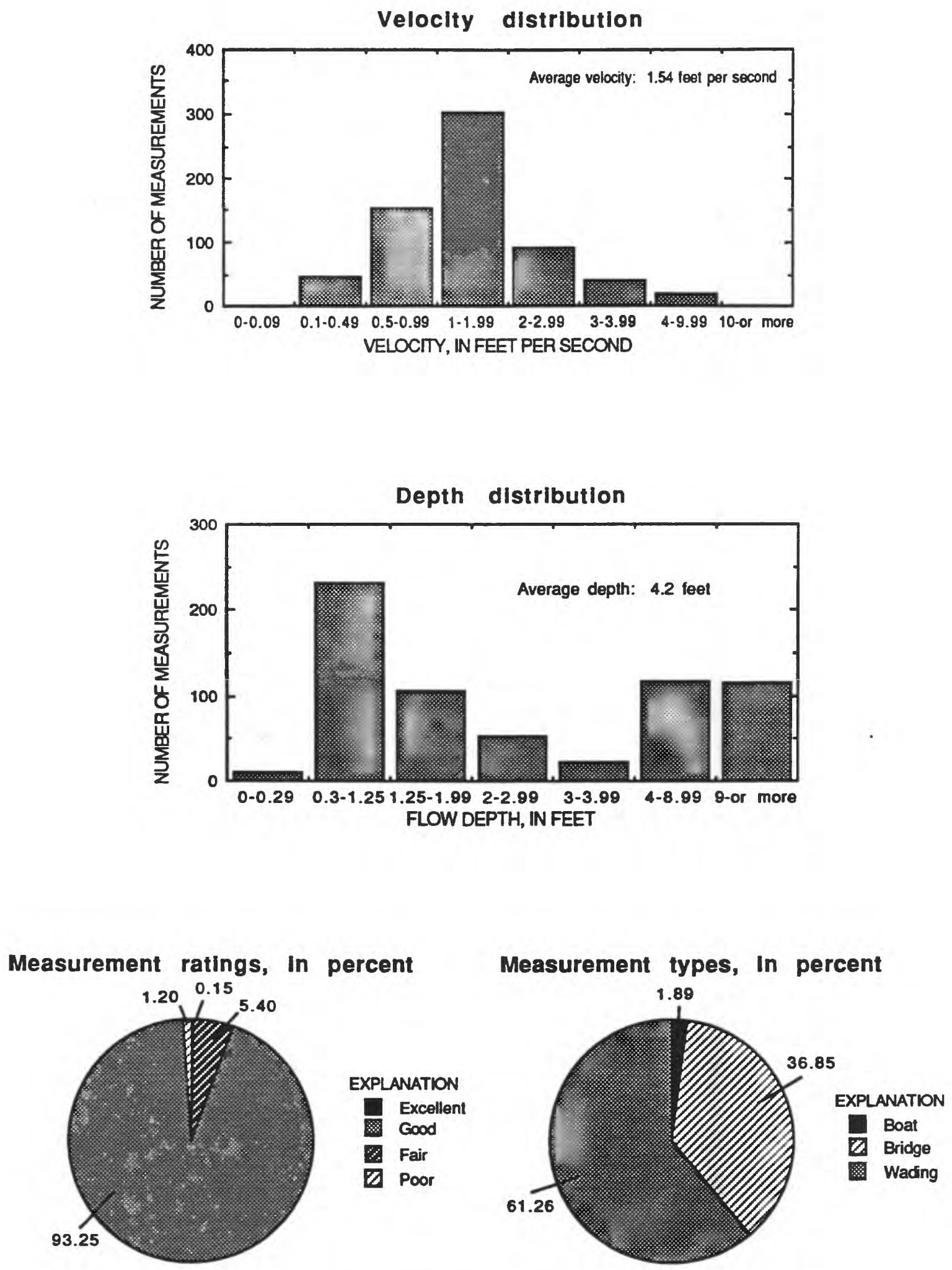

Figure 33.--Mississippi's velocity and depth frequency distributions and percentage of measurements by measurement rating and by measurement type for water year 1990 . 

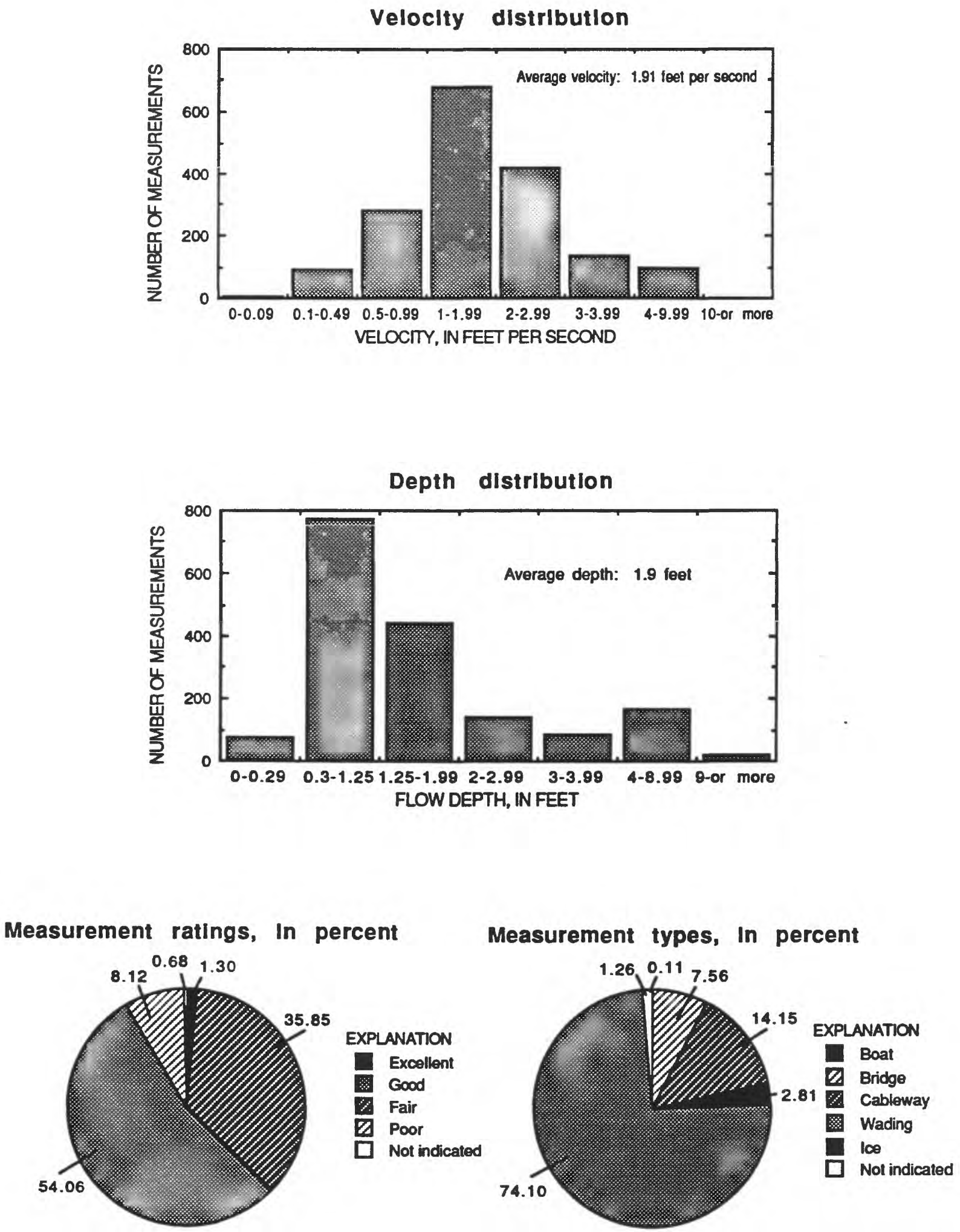

Figure 34.--Montana's velocity and depth frequency distributions and percentage of measurements by measurement rating and by measurement type for water year 1990 . 

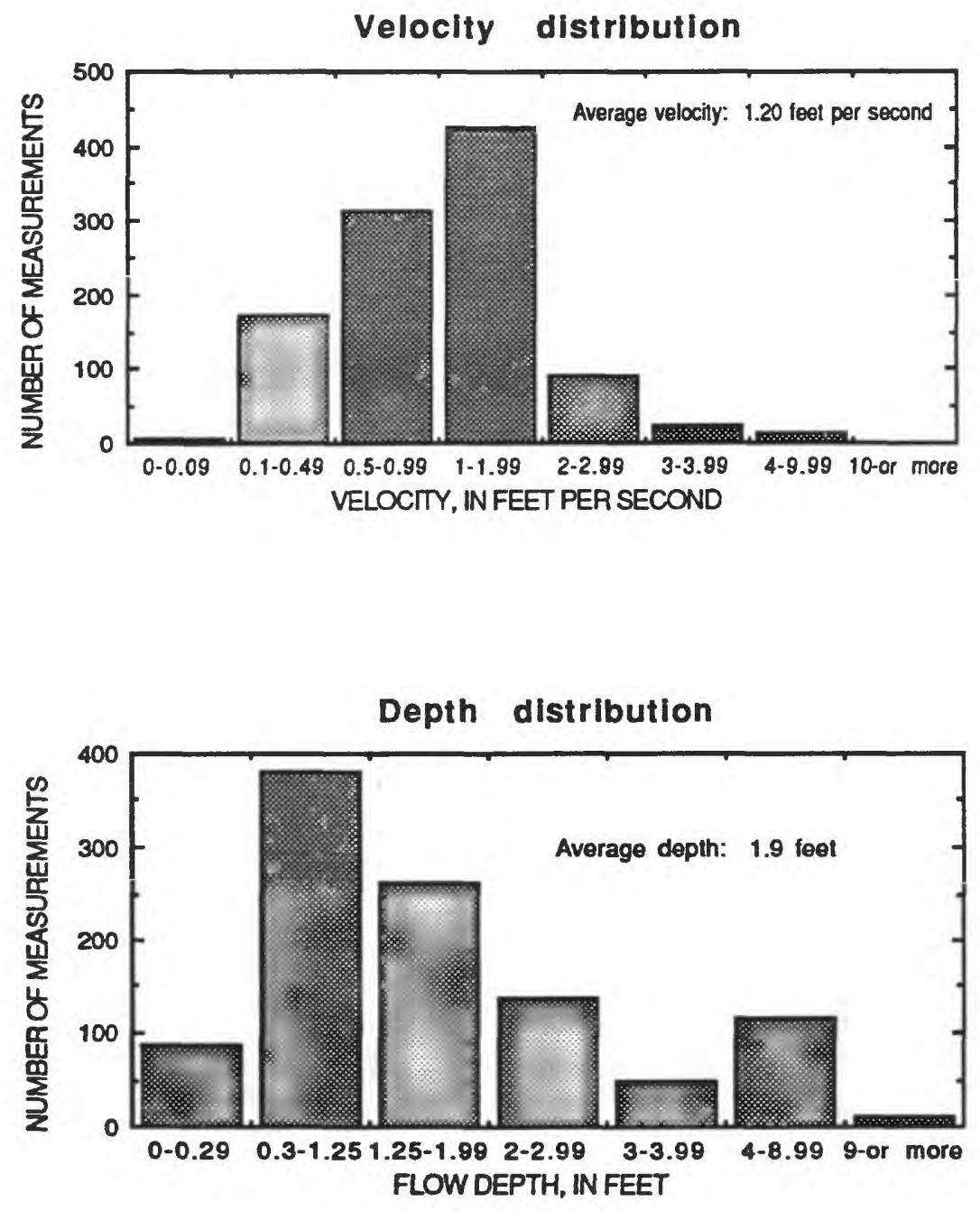

Measurment ratings, In percent

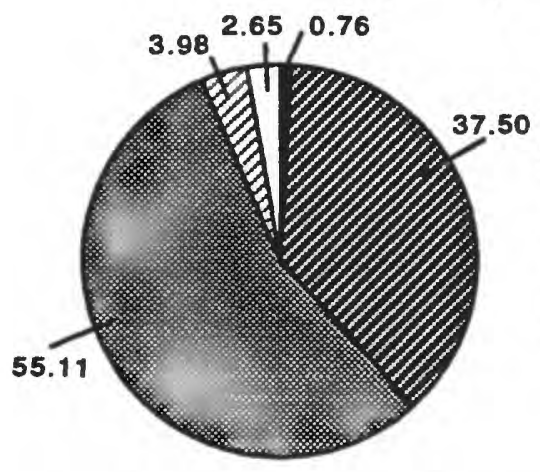

Measurement types, in percent

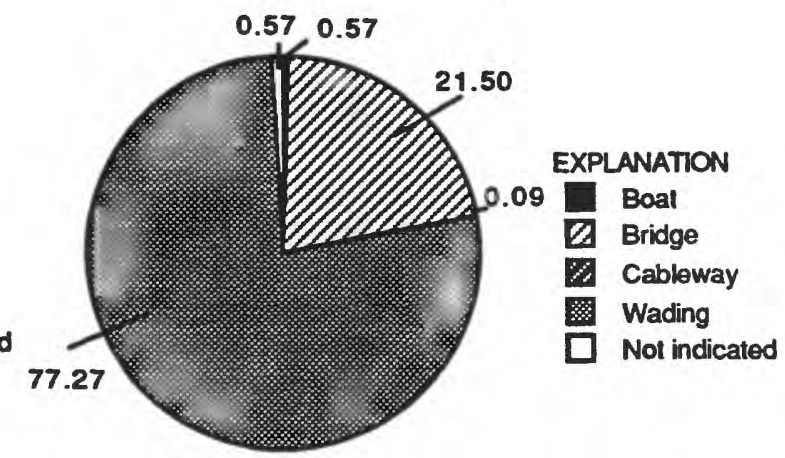

Figure 35.--North Carolina's velocity and depth frequency distributions and percentage of measurements by measurement rating and by measurement type for water year 1990 . 

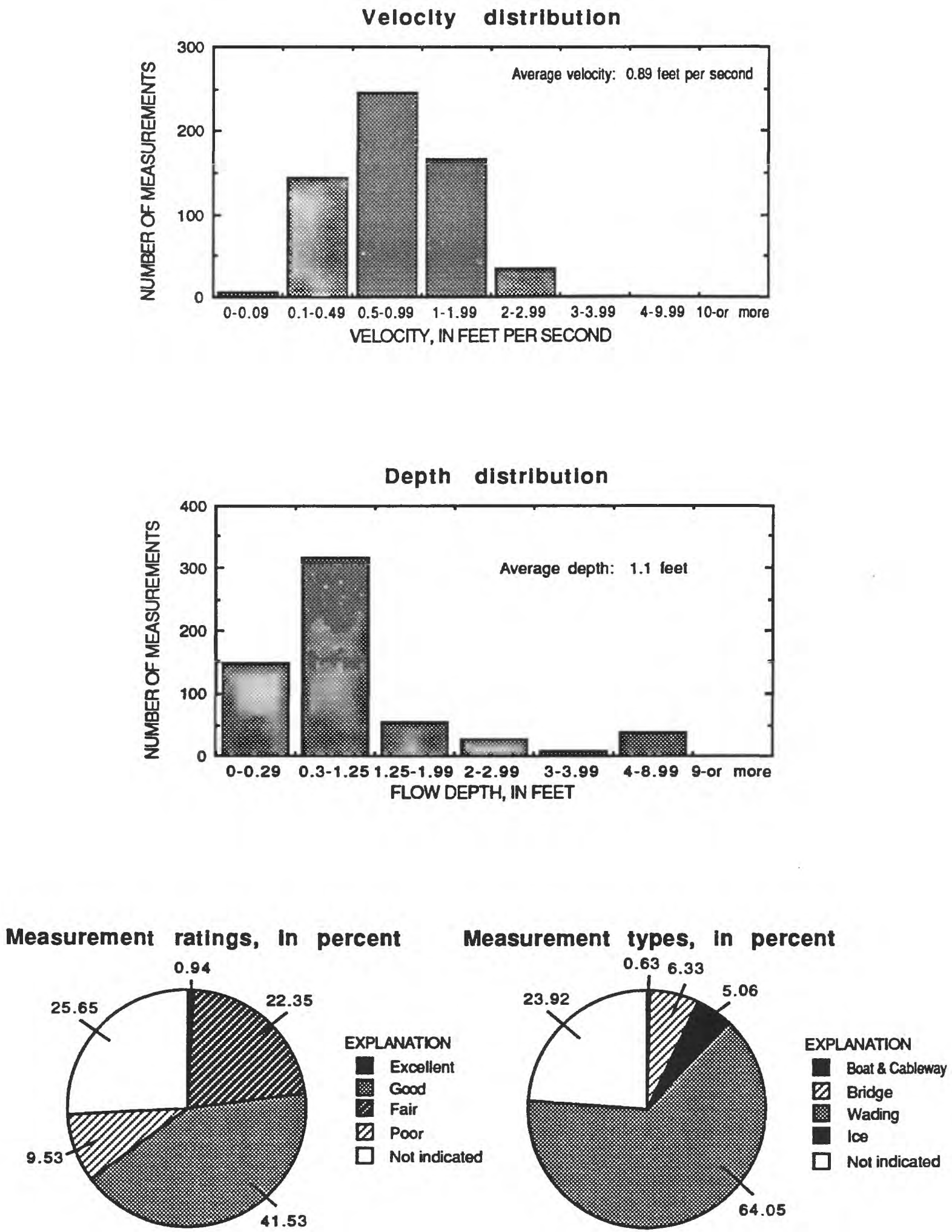

Figure 36.--North Dakota's velocity and depth frequency distributions and percentage of measurements by measurement rating and by measurement type for water year 1990 . 

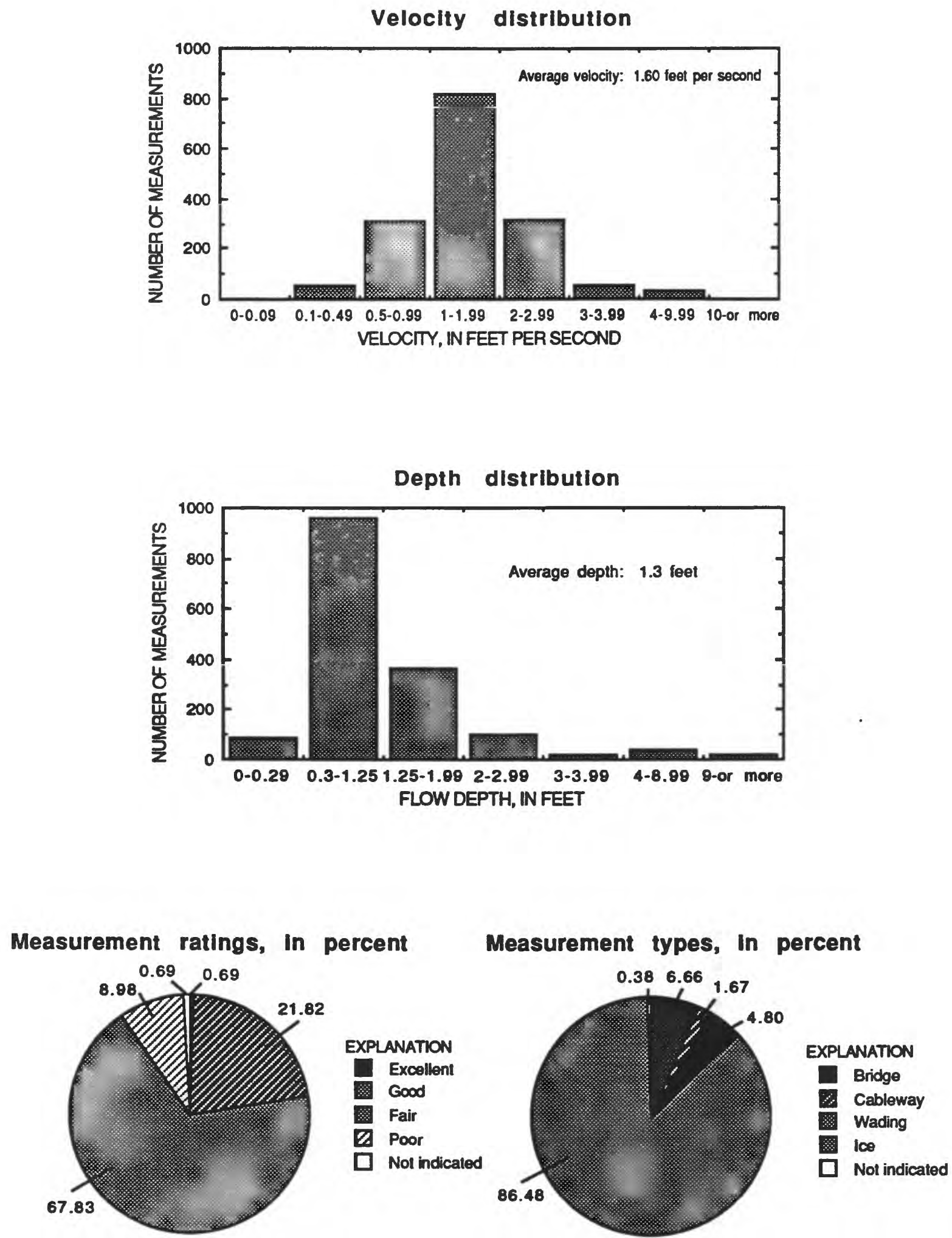

Figure 37.--Nebraska's velocity and depth frequency distributions and percentage of measurements by measurement rating and by measurement type for water year 1990 . 

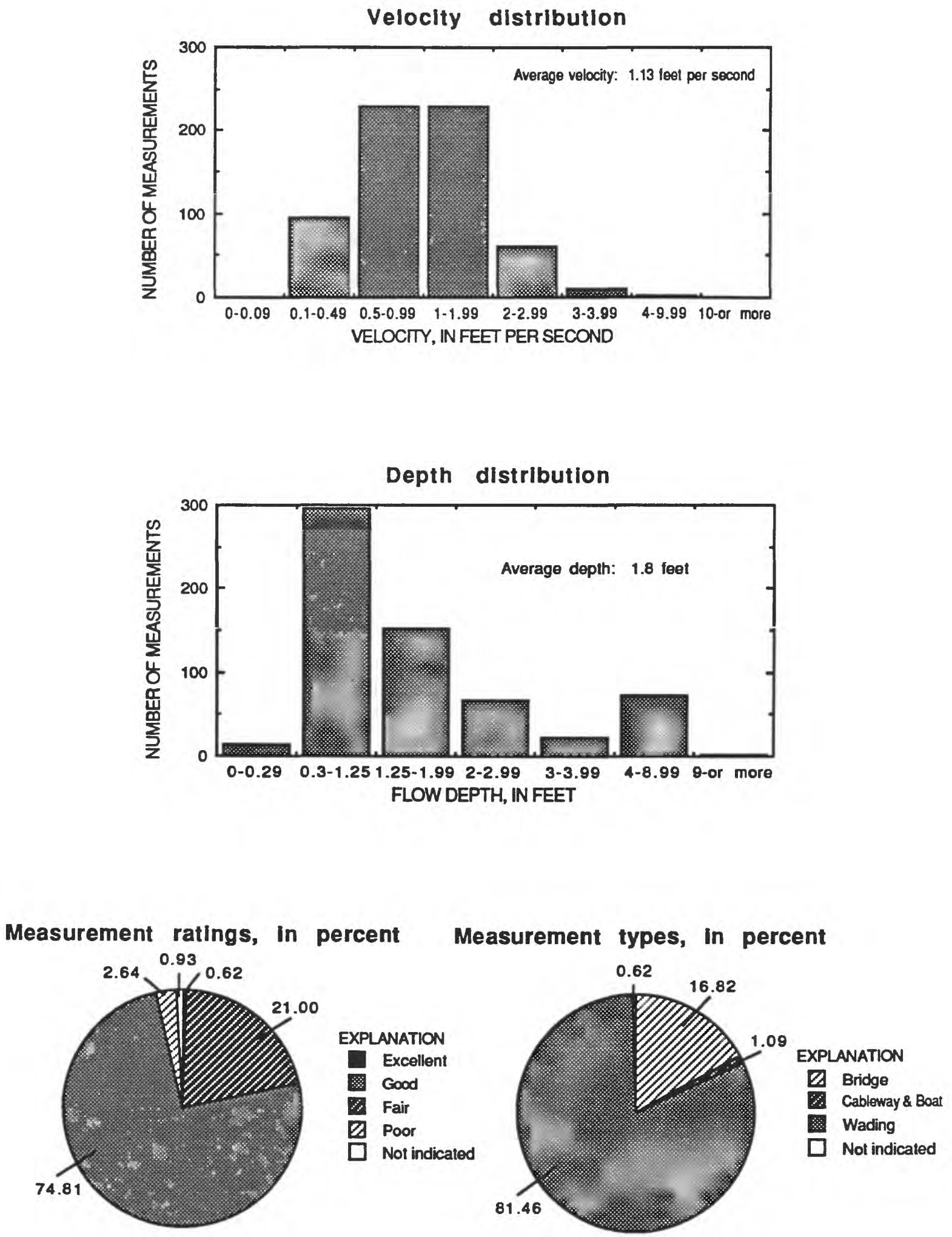

Figure 38.--New Jersey's velocity and depth frequency distributions and percentage of measurements by measurement rating and by measurement type for water year 1990 . 


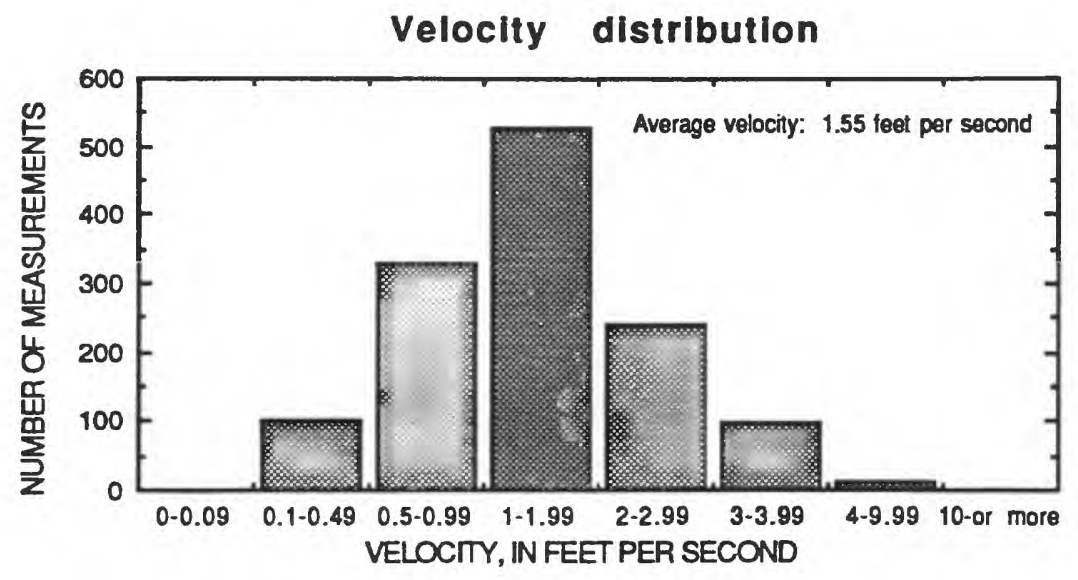

Depth distribution

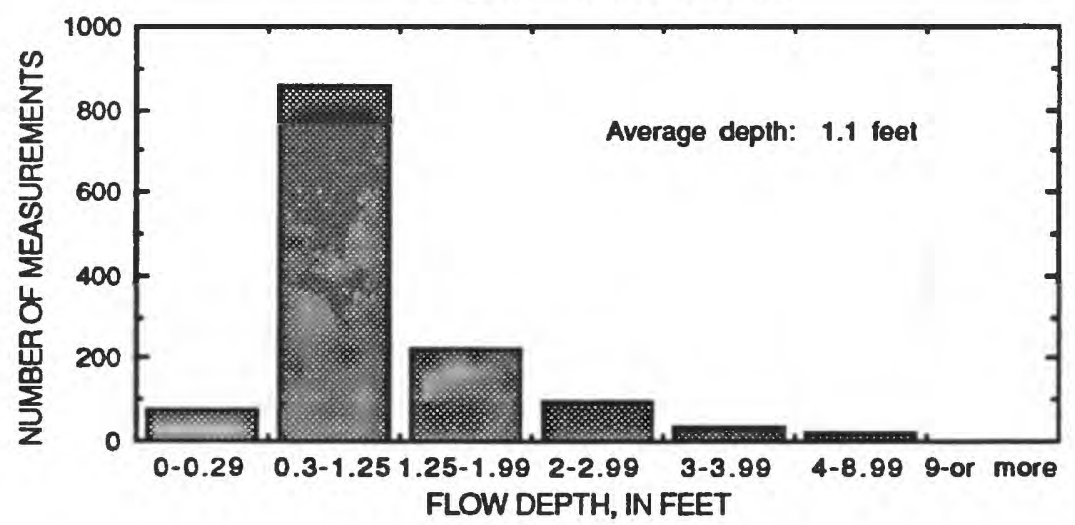

Measurement ratings, In percent

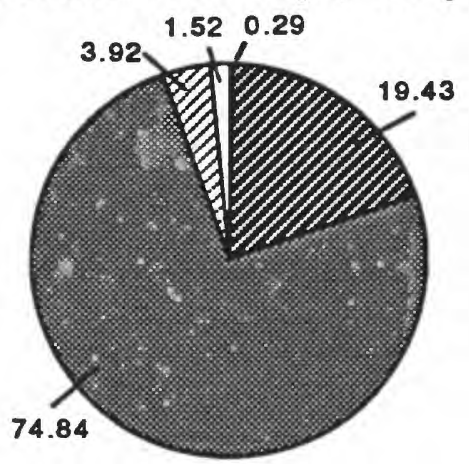

Measurement types, in percent

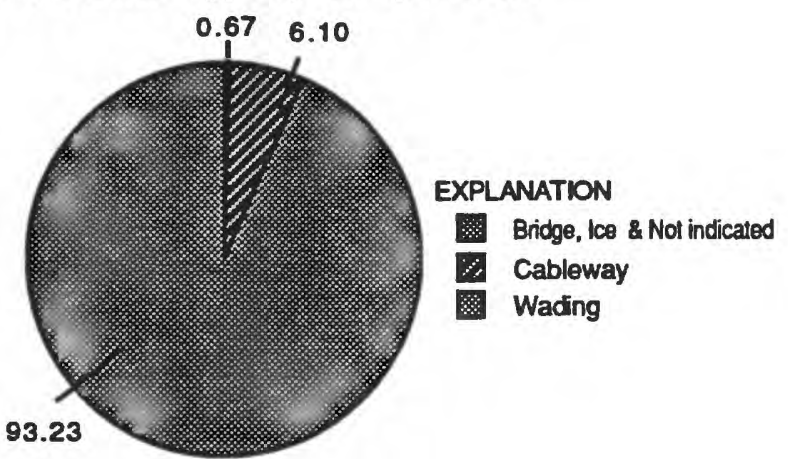

Figure 39.--New Mexico's velocity and depth frequency distributions and percentage of measurements by measurement rating and by measurement type for water year 1990 . 

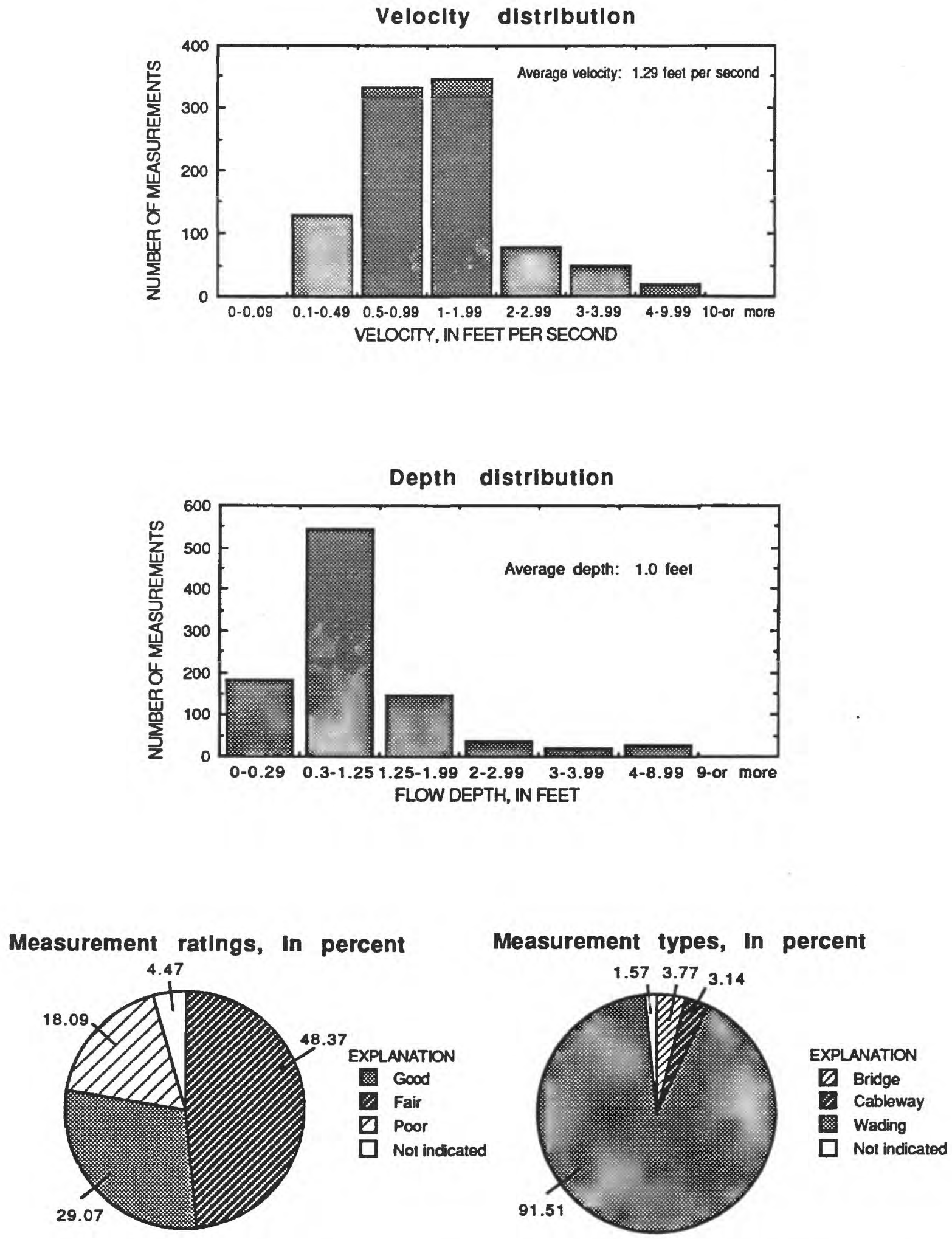

Figure 40.--Nevada's velocity and depth frequency distributions and percentage of measurements by measurement rating and by measurement type for water year 1990 . 


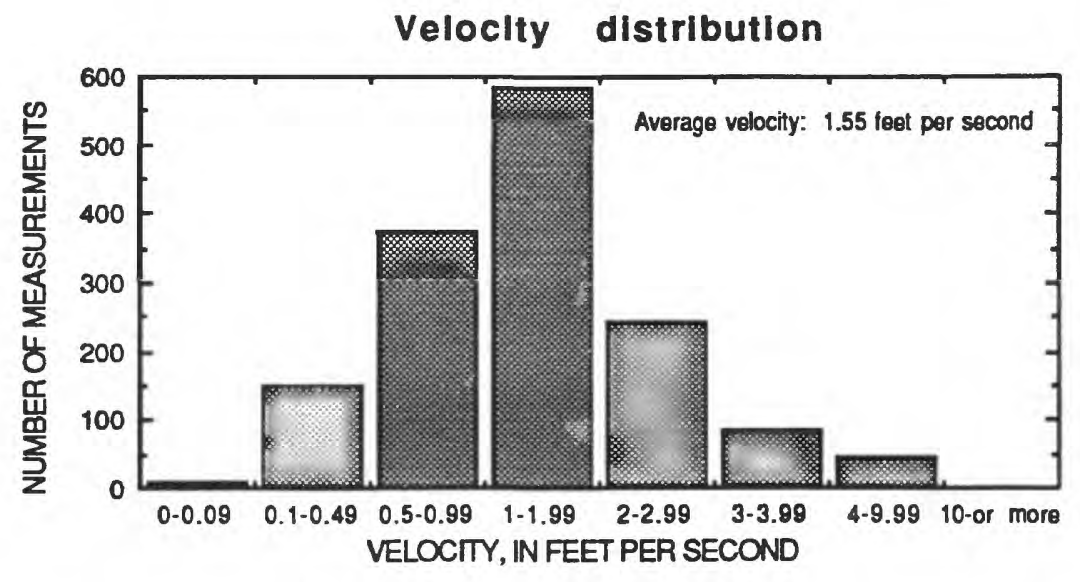

Depth distribution

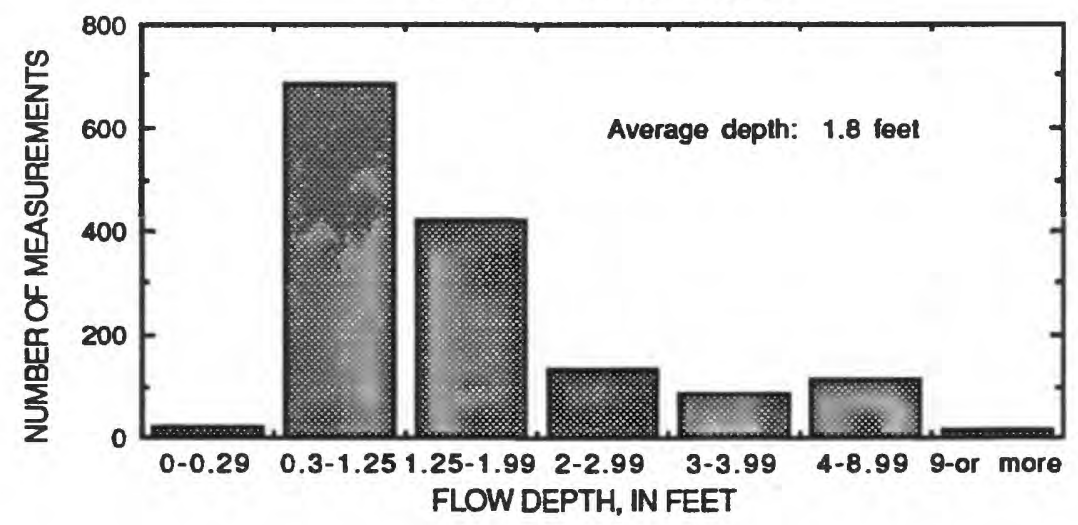

Measurement ratings, In percent

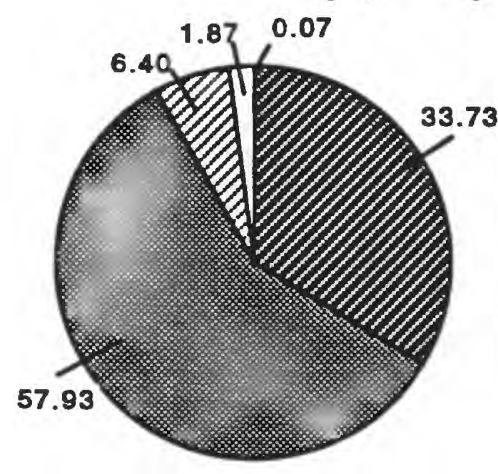

Measurement types, in percent

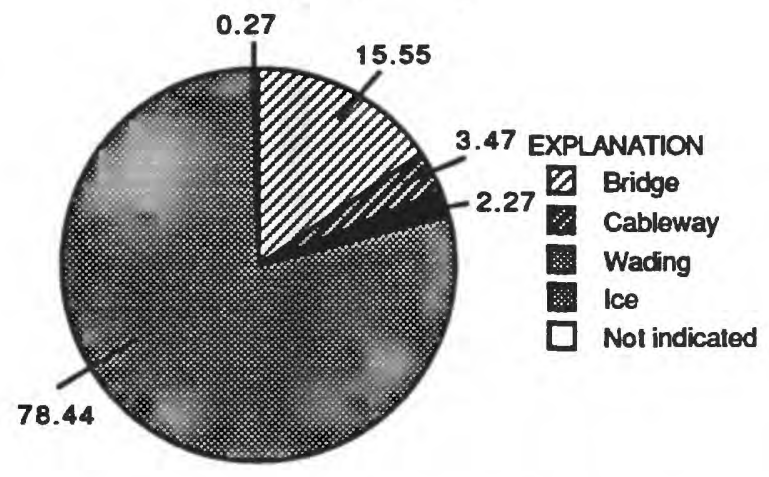

Figure 41.--New York's velocity and depth frequency distributions and percentage of measurements by measurement rating and by measurement type for water year 1990 . 

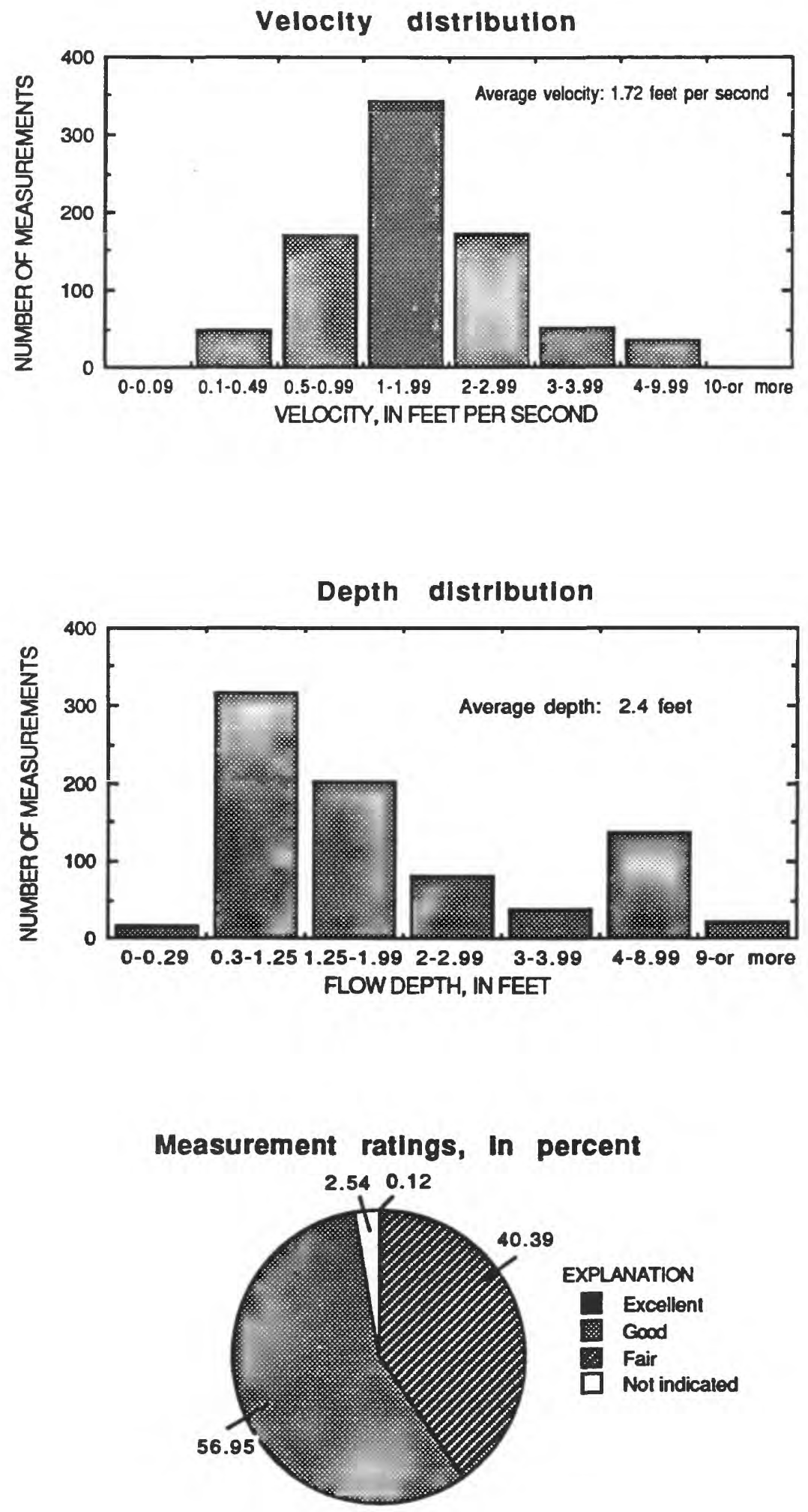

Figure 42.--Ohio's velocity and depth frequency distributions and percentage of measurements by measurement rating for water year 1990 


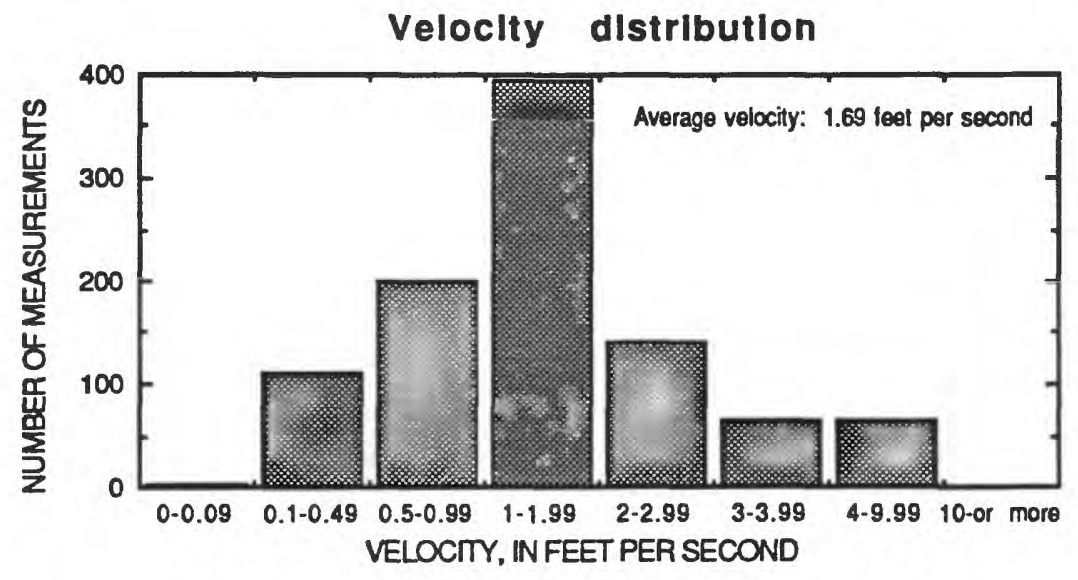

Depth distribution

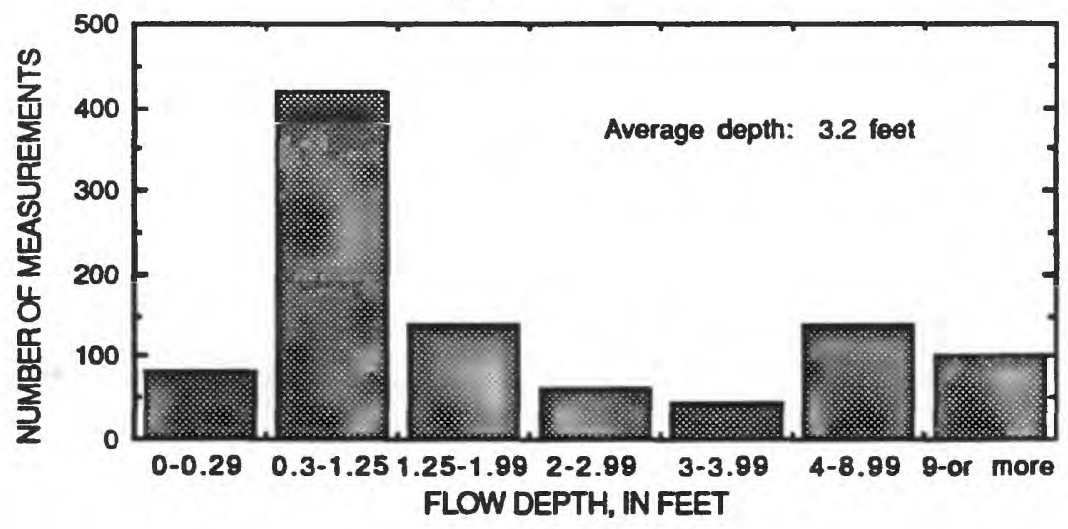

Measurement ratings, In percent

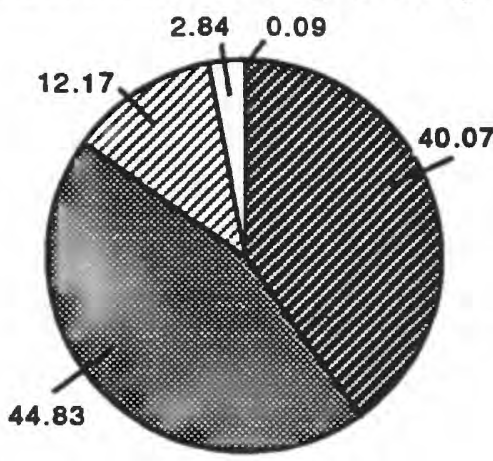

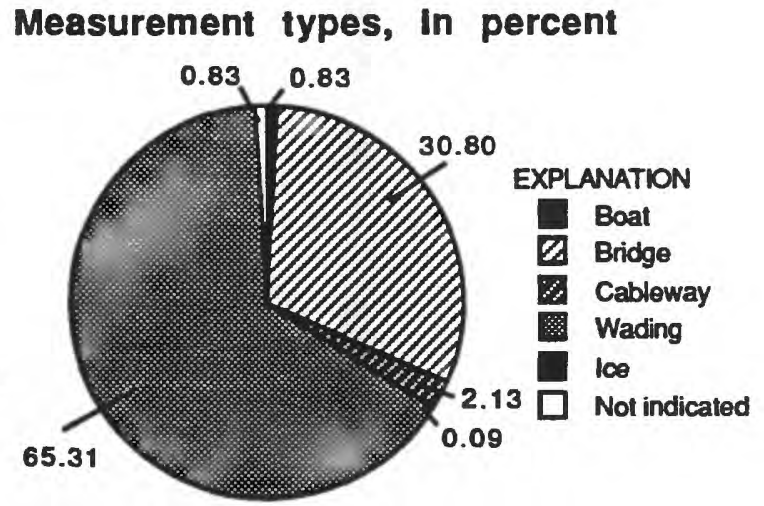

Figure 43.--Oklahoma's velocity and depth frequency distributions and percentage of measurements by measurement rating and by measurement type for water year 1990 . 

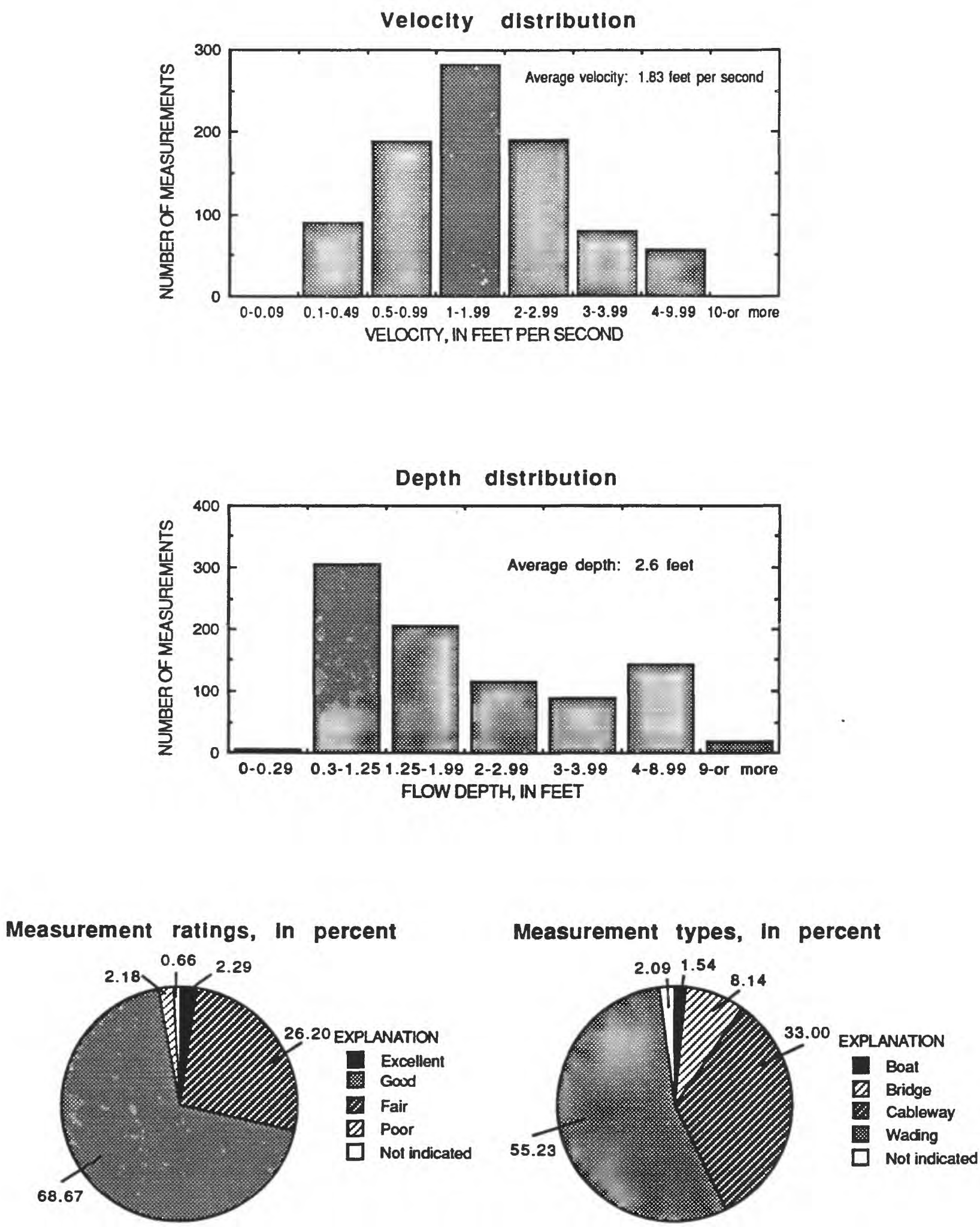

Figure 44.--Oregon's velocity and depth frequency distributions and percentage of measurements by measurement rating and by measurement type for water year 1990 . 

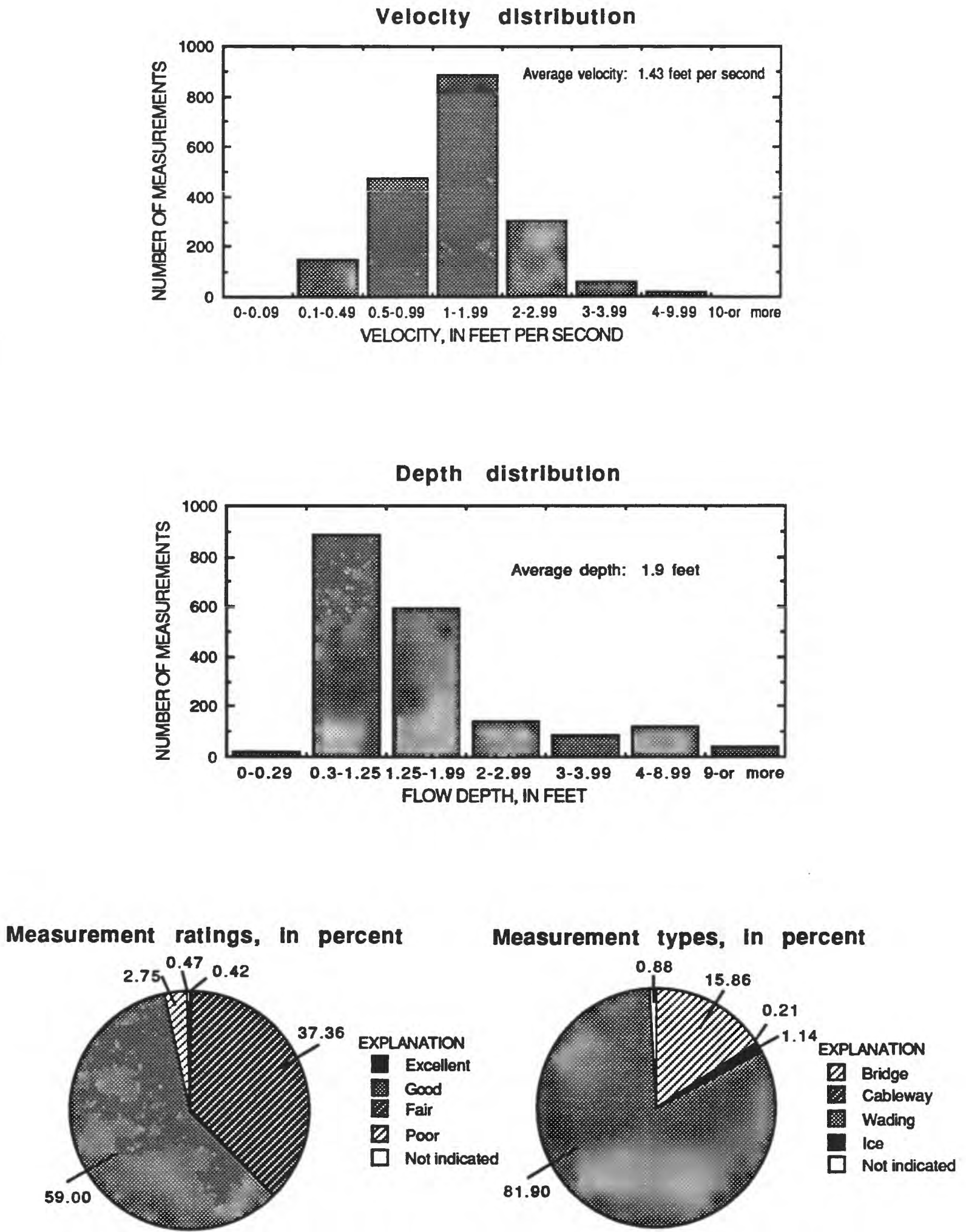

Figure 45.--Pennsylvania's velocity and depth frequency distributions and percentage of measurements by measurement rating and by measurement type for water year 1990 . 


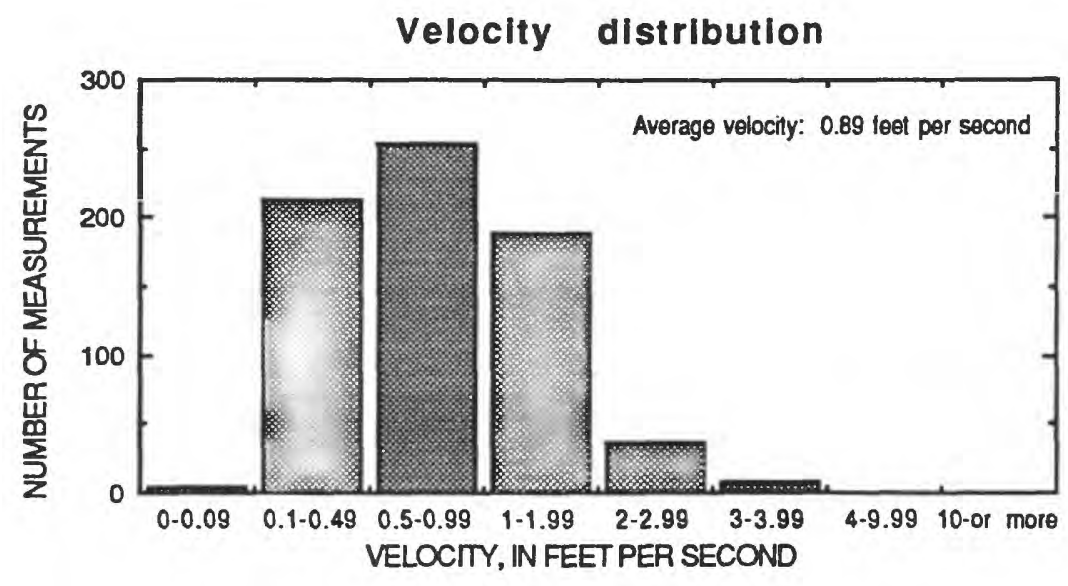

Depth distribution

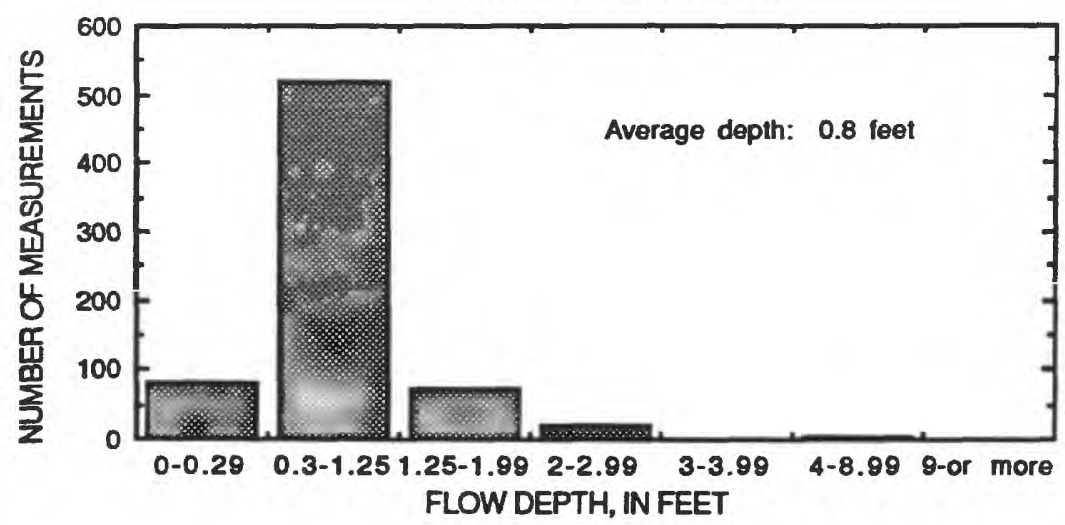

Measurement ratings, in percent

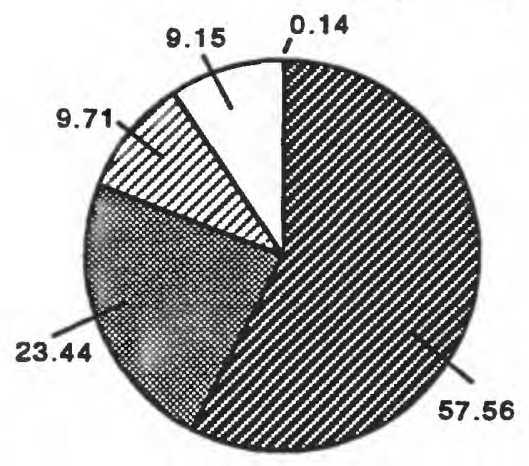

Measurement types, in percent

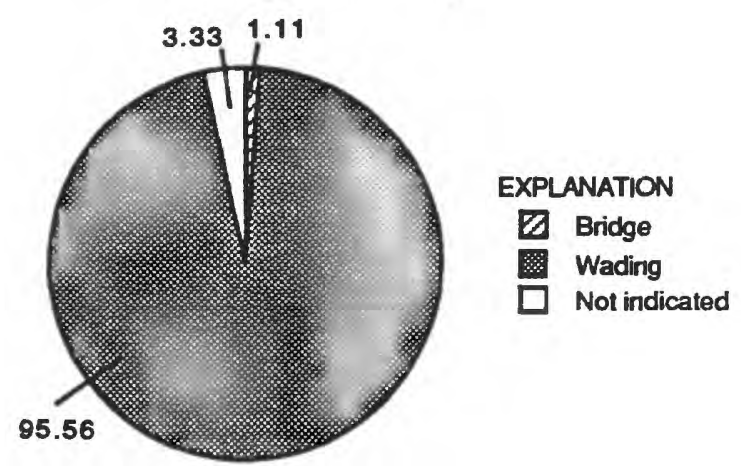

Figure 46.--Puerto Rico's velocity and depth frequency distributions and percentage of measurements by measurement rating and by measurement type for water year 1990 . 

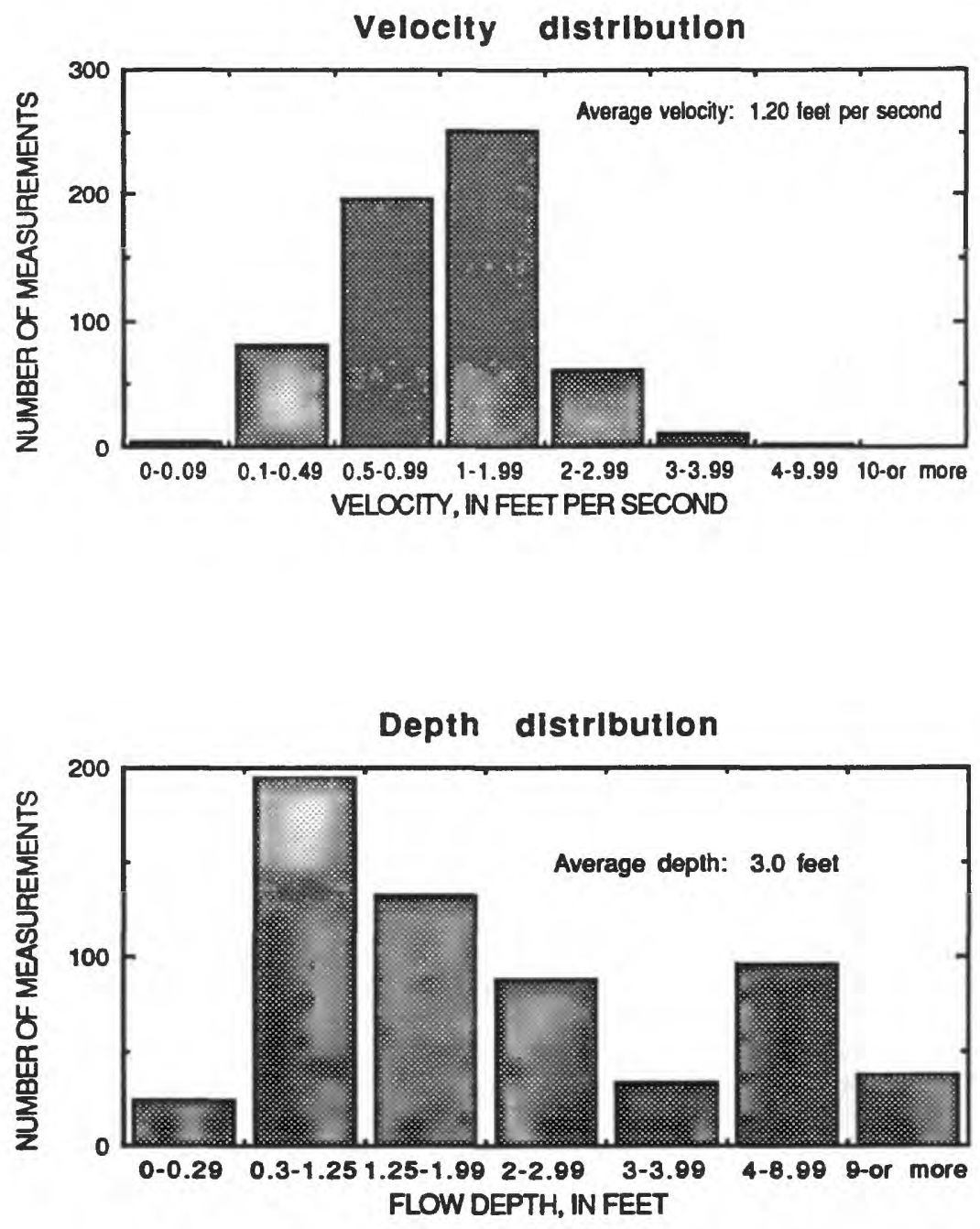

Measurement ratings, in percent

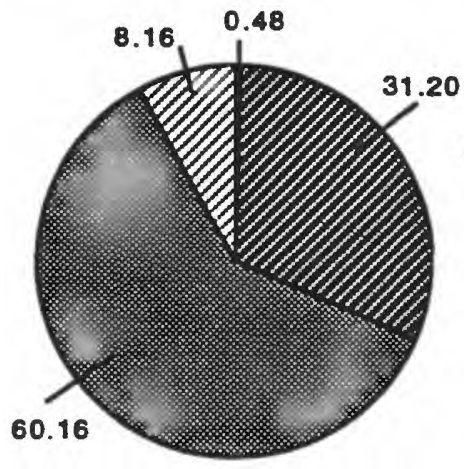

Measurement types, in percent

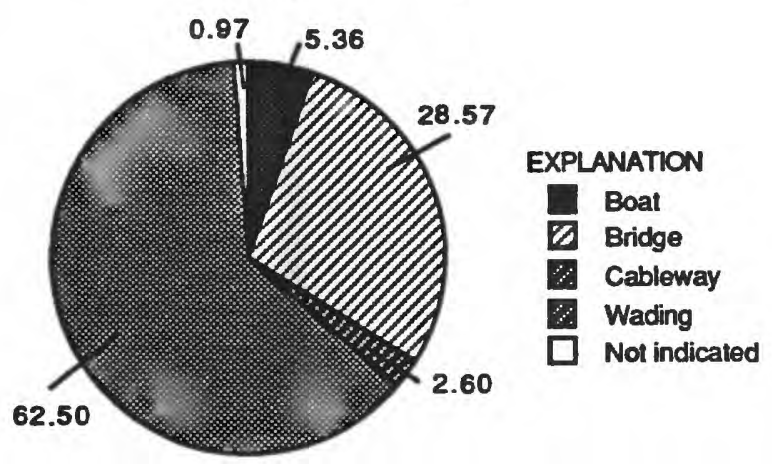

Figure 47.--South Carolina's velocity and depth frequency distributions and percentage of measurements by measurement rating and by measurement type for water year 1990 . 


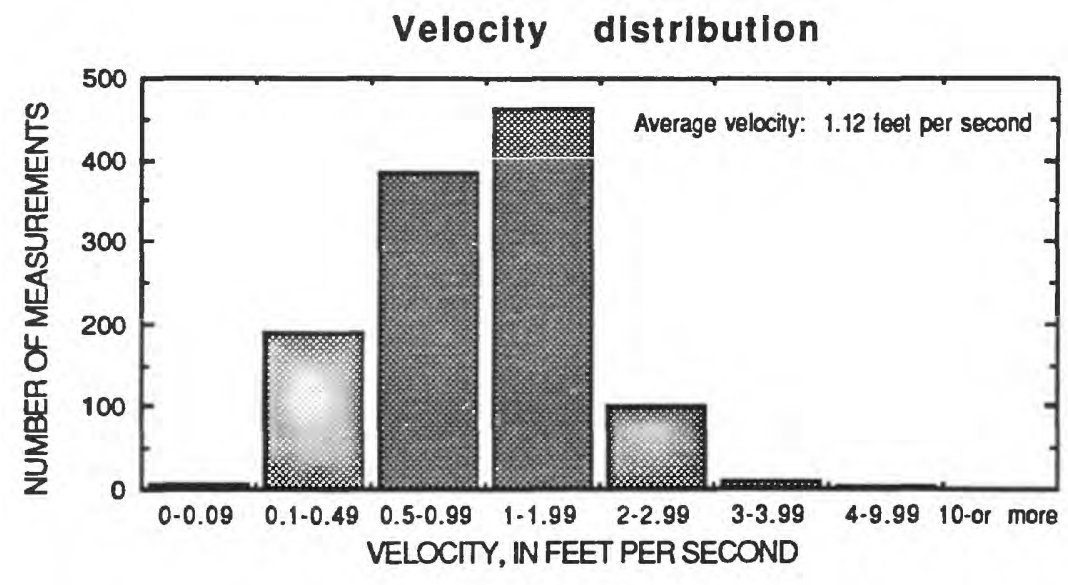

Depth distribution

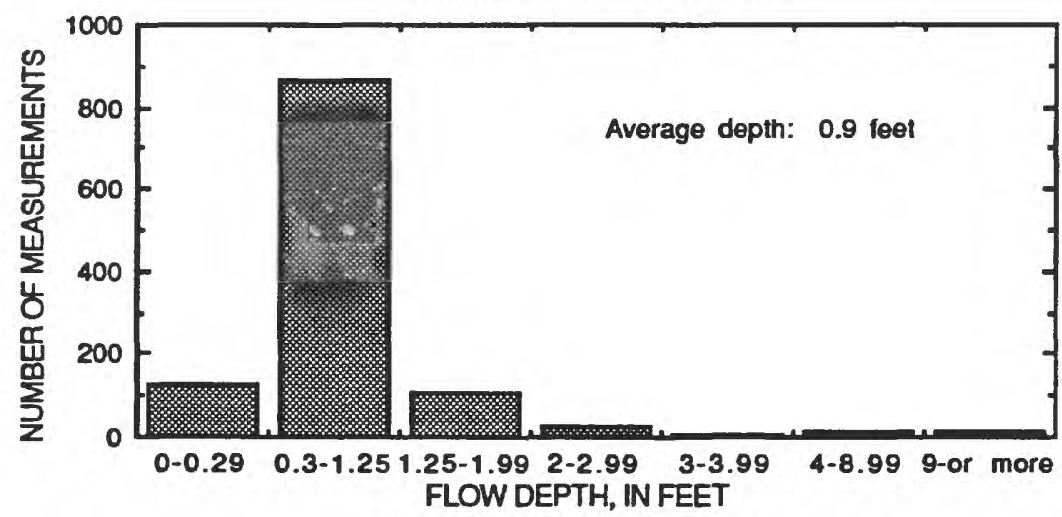

Measurement ratings, in percent

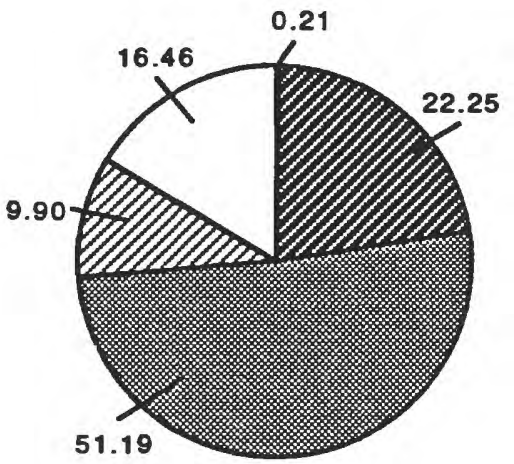

Measurement types, In percent

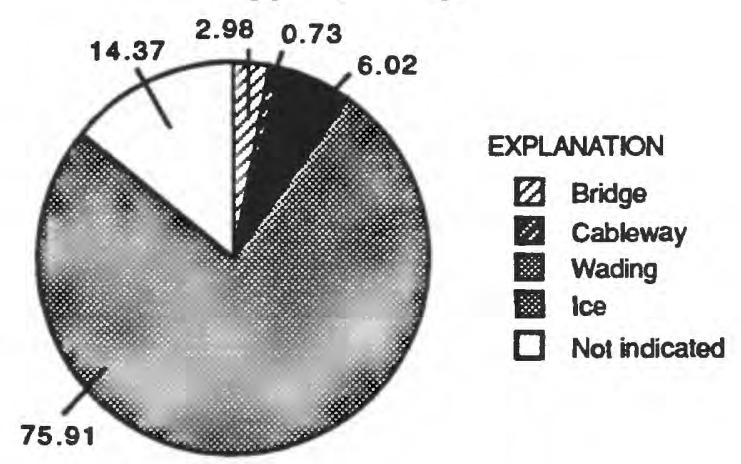

Figure 48.--South Dakota's velocity and depth frequency distributions and percentage of measurements by measurement rating and by measurement type for water year 1990 . 

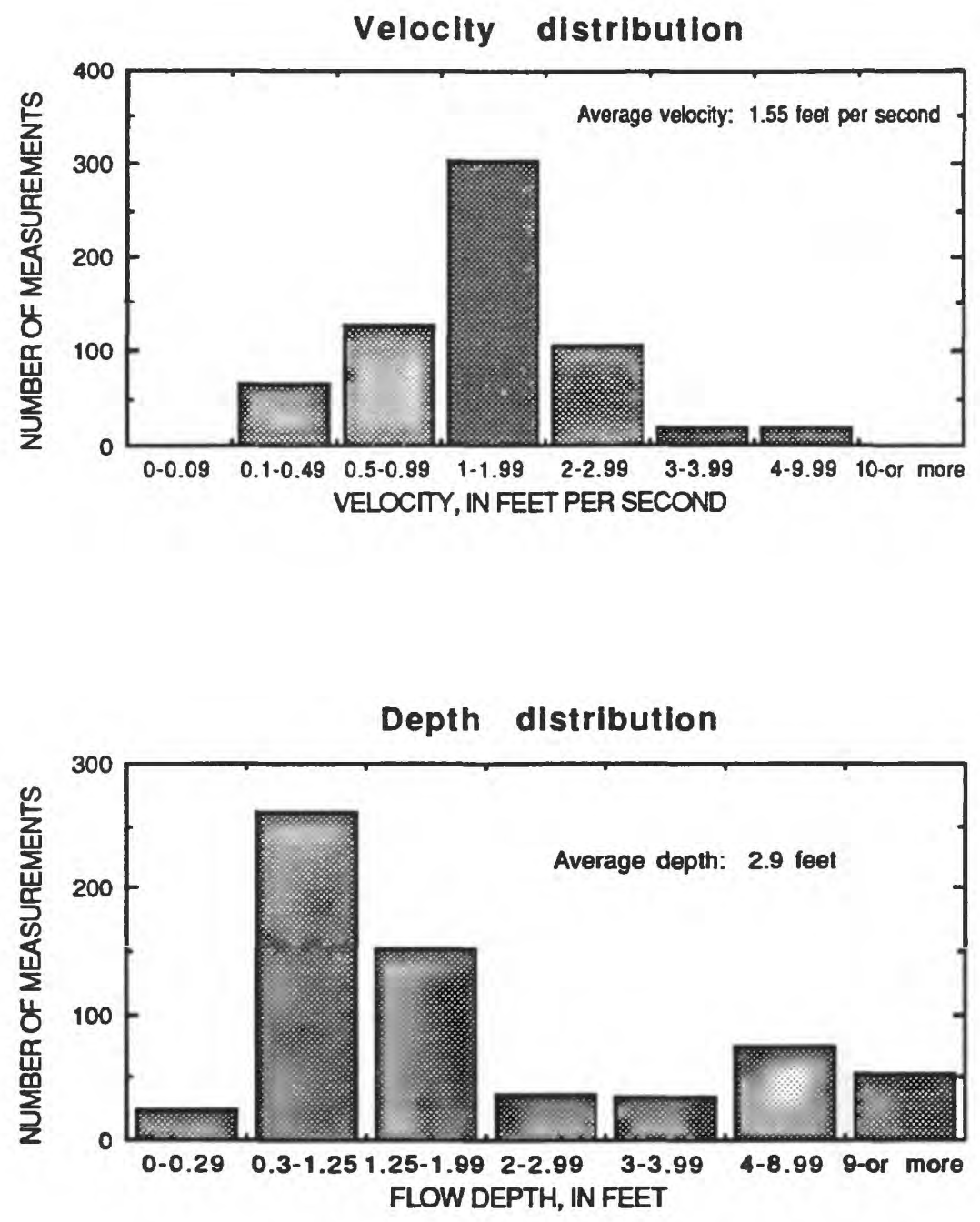

Measurement ratings, In percent

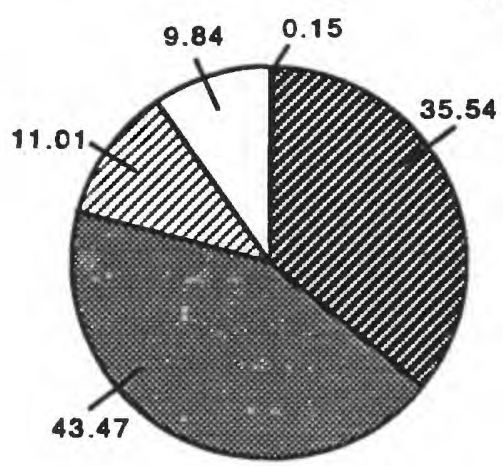

Measurement types, In percent

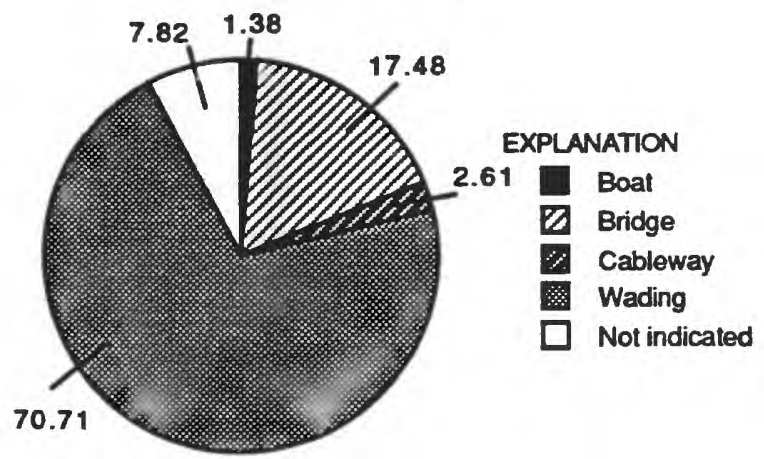

Figure 49.--Tennessee's velocity and depth frequency distributions and percentage of measurements by measurement rating and by measurement type for water year 1990 . 

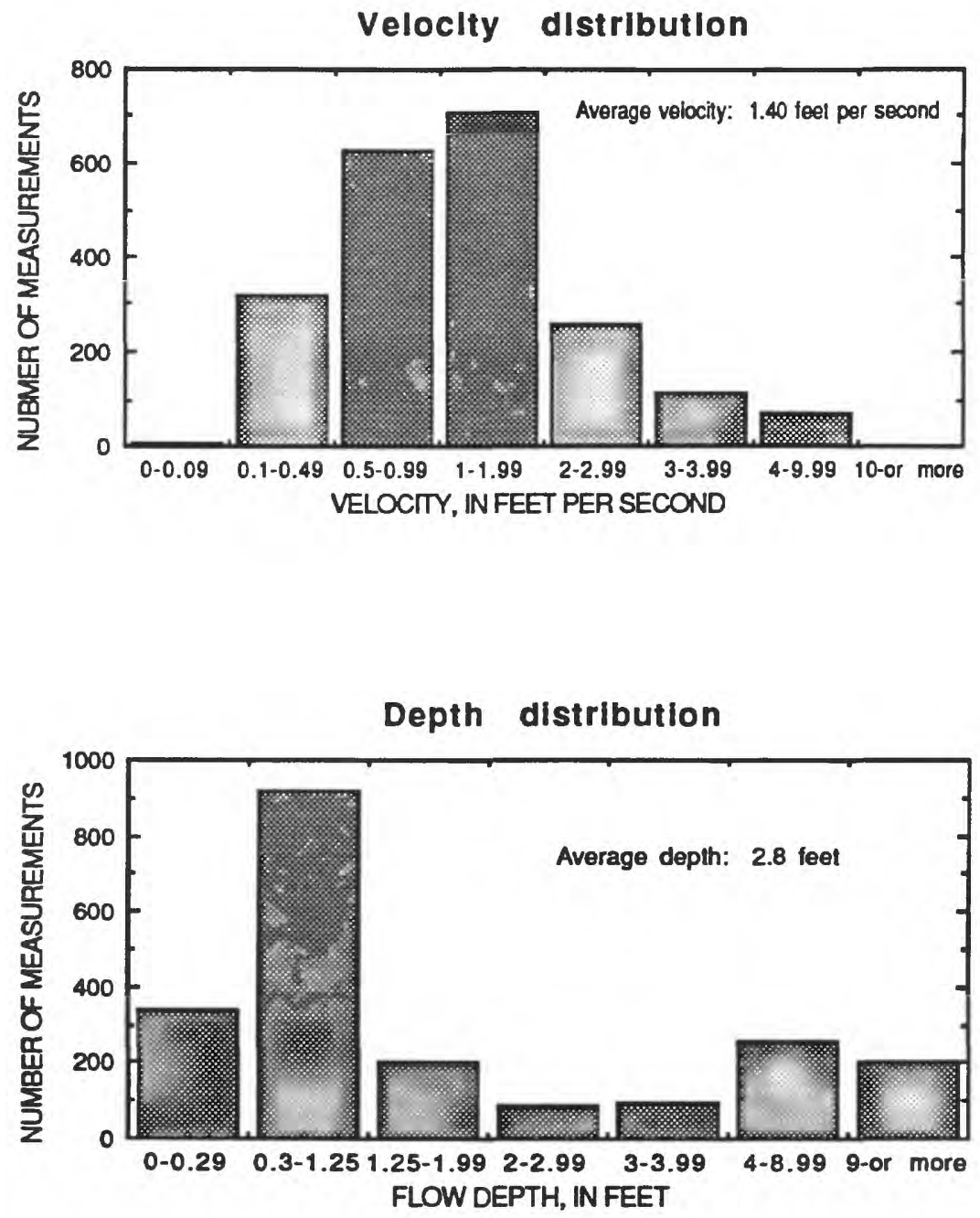

Measurement ratings, In percent

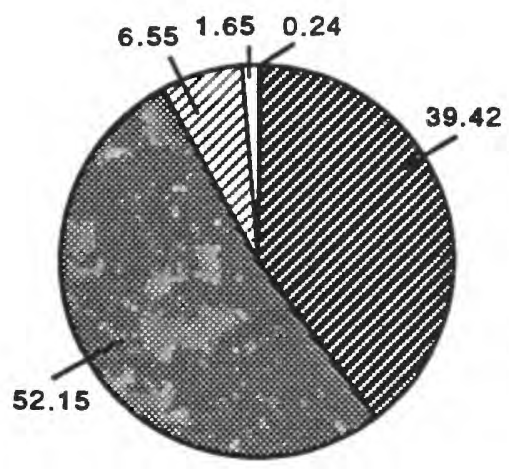

Measurement types, in percent

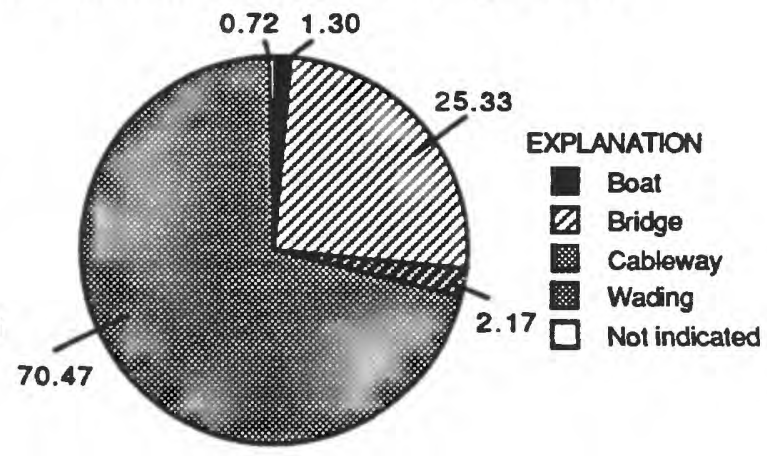

Figure 50.--Texas's velocity and depth frequency distributions and percentage of measurements by measurement rating and by measurement type for water year 1990 . 


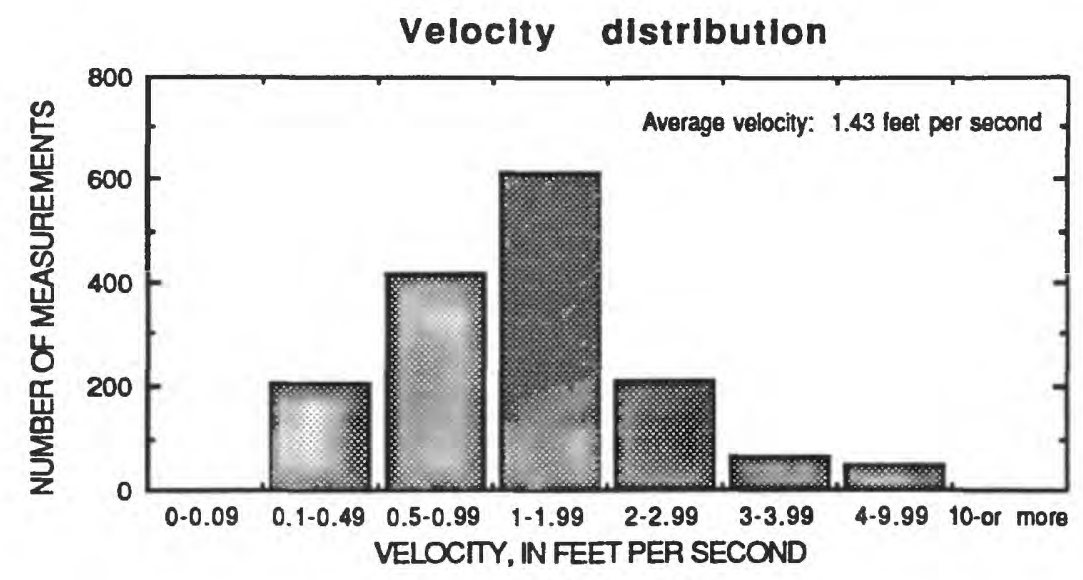

Depth distribution

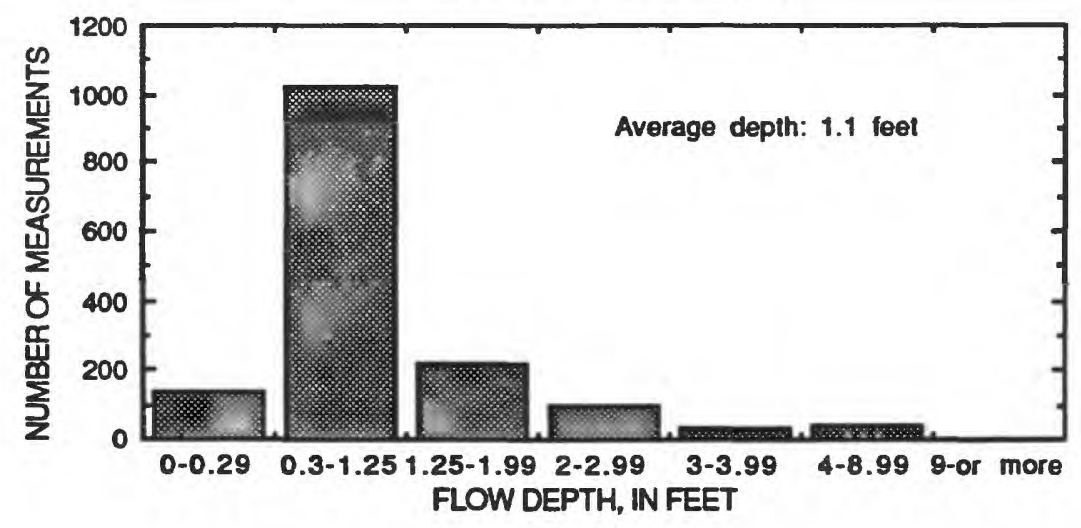

Measurement ratings, In percent

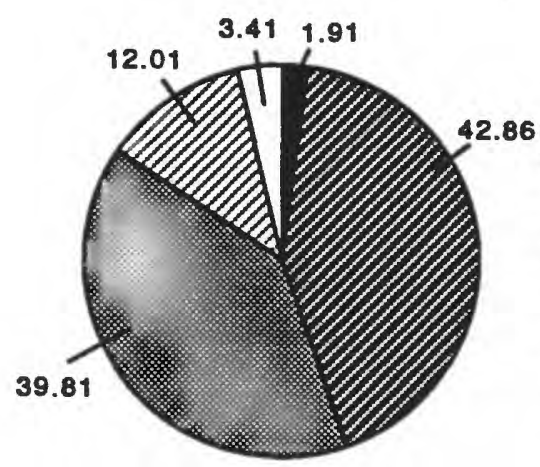

Measurement types, In percent

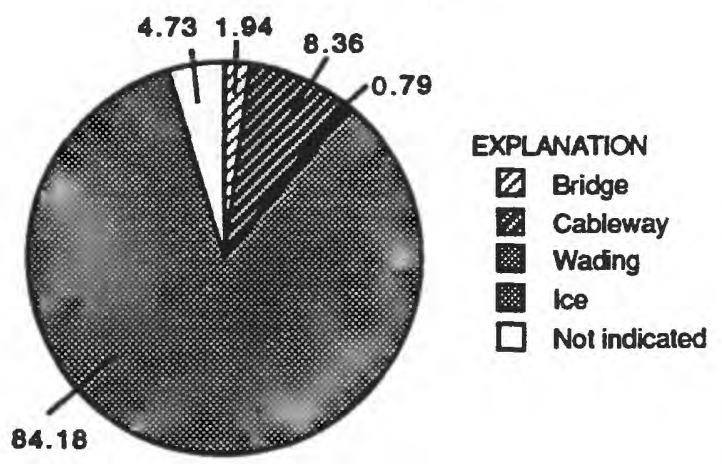

Figure 51.--Utah's velocity and depth frequency distributions and percentage of measurements by measurement rating and by measurement type for water year 1990 . 

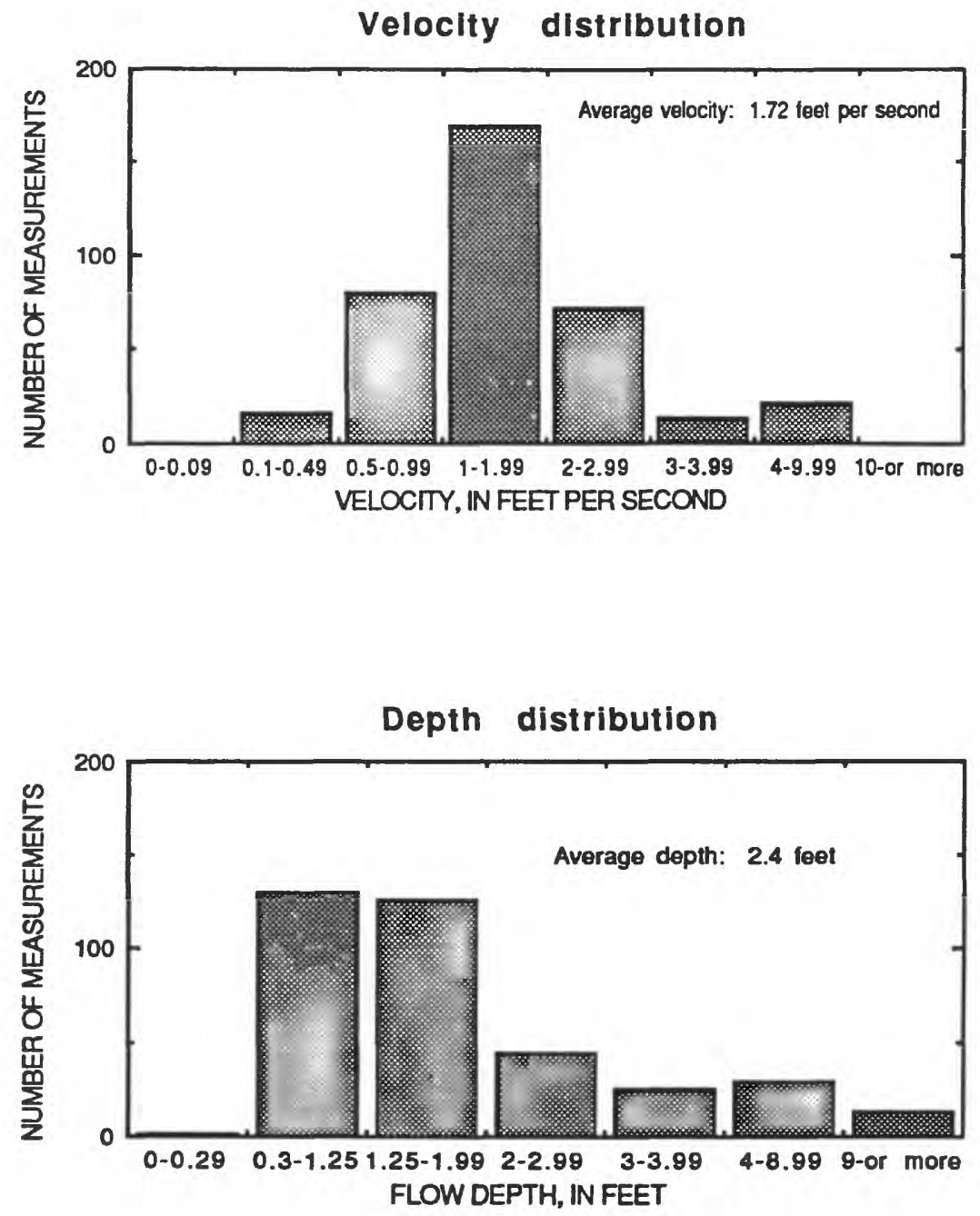

Measurement ratings, in percent

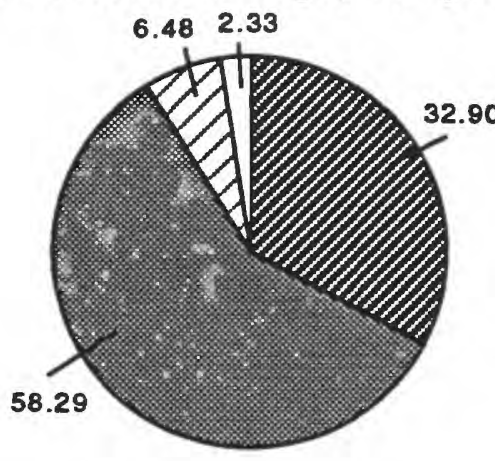

Measurement types, in percent

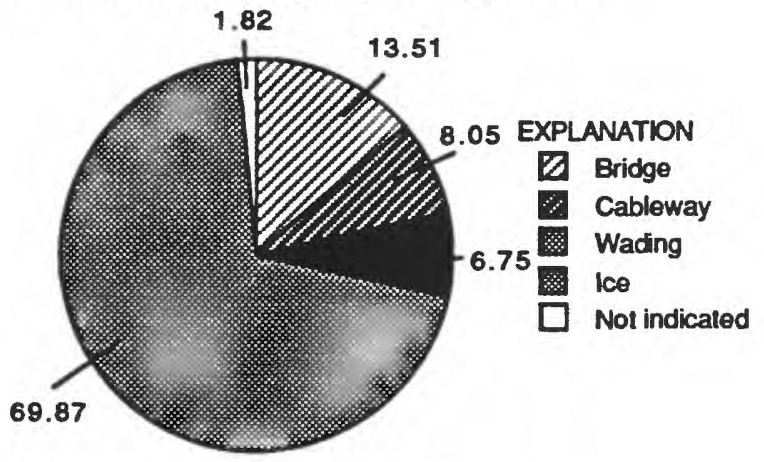

Figure 52.--Vermont's and New Hampshire velocity and depth frequency distributions and percentage of measurements by measurement rating and by measurement type for water year 1990 . 

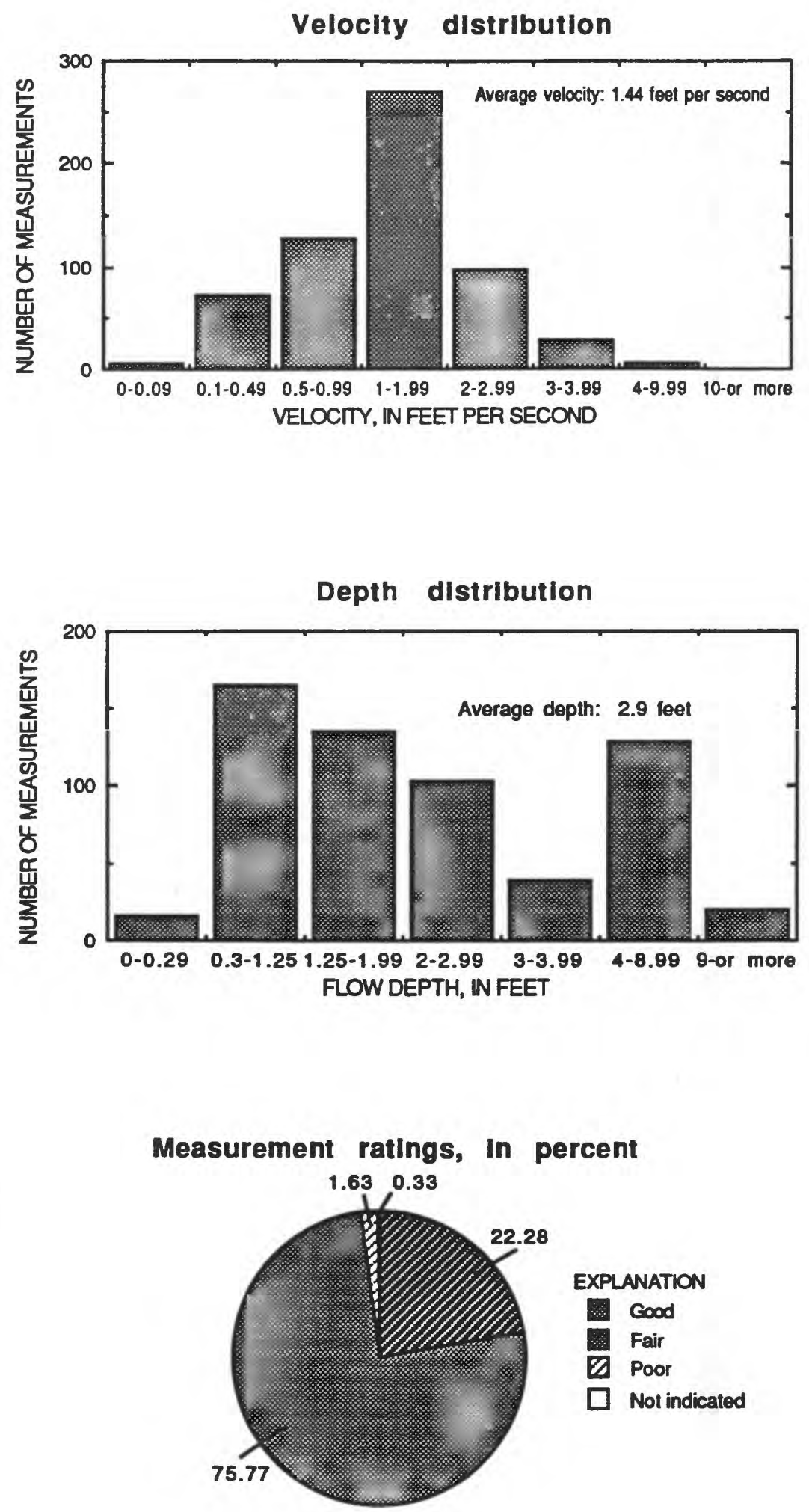

Figure 53.--Virginia's velocity and depth frequency distributions and percentage of measurements by measurement rating for water year 1990 . 

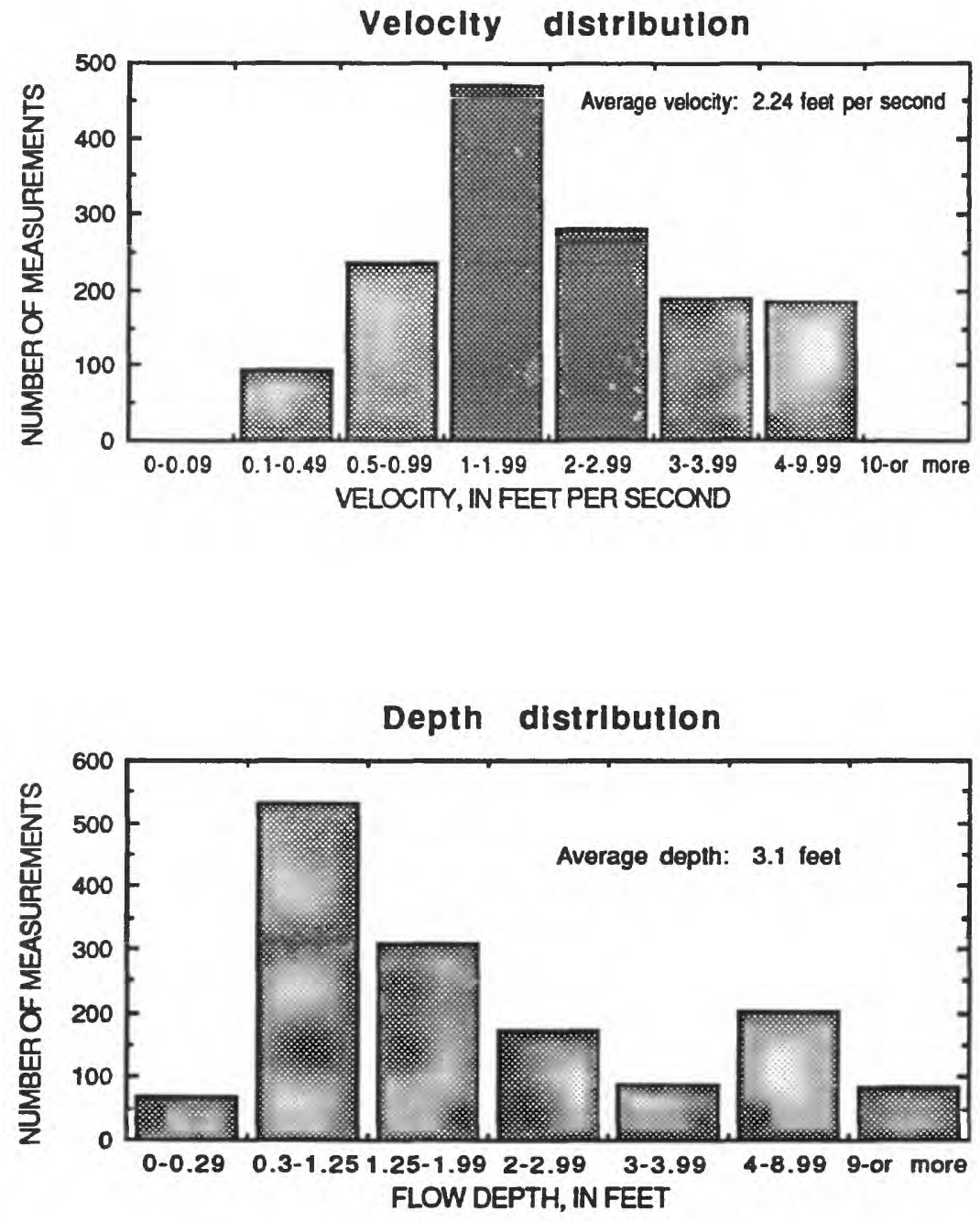

Measurement ratings, In percent

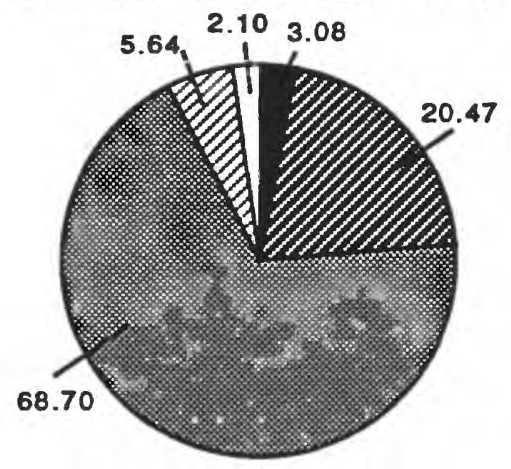

Measurement types, In percent

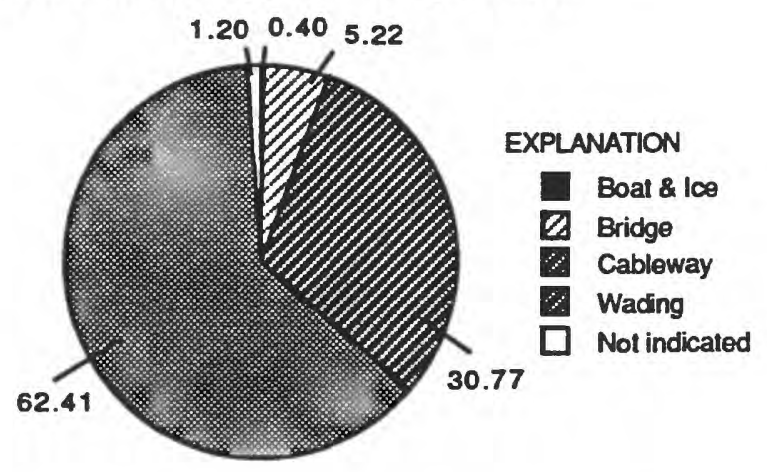

Figure 54.--Washington's velocity and depth frequency distributions and percentage of measurements by measurement rating and by measurement type for water year 1990 . 

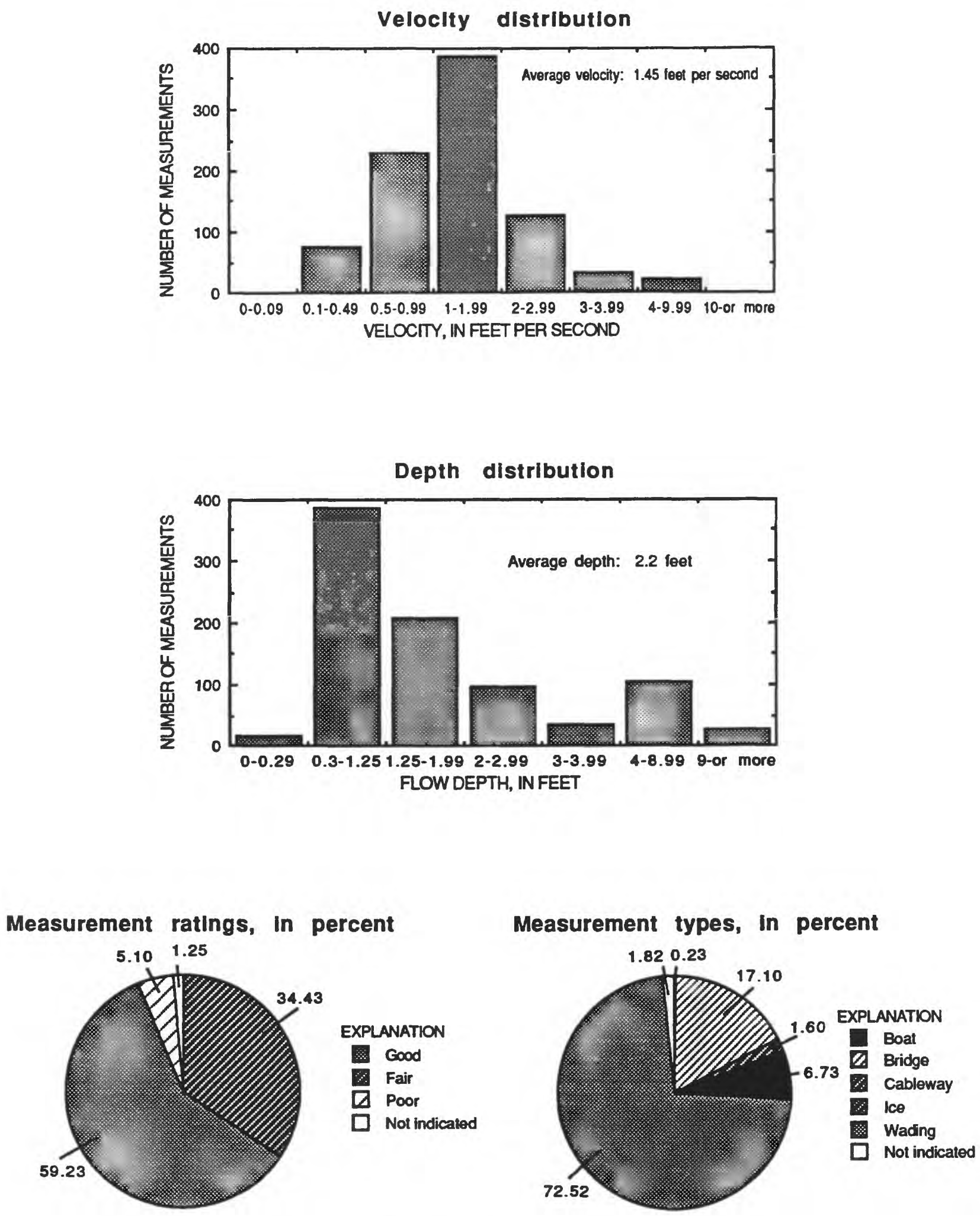

Figure 55.--Wisconsin's velocity and depth frequency distributions and percentage of measurements by measurement rating and by measurement type for water year 1990 . 

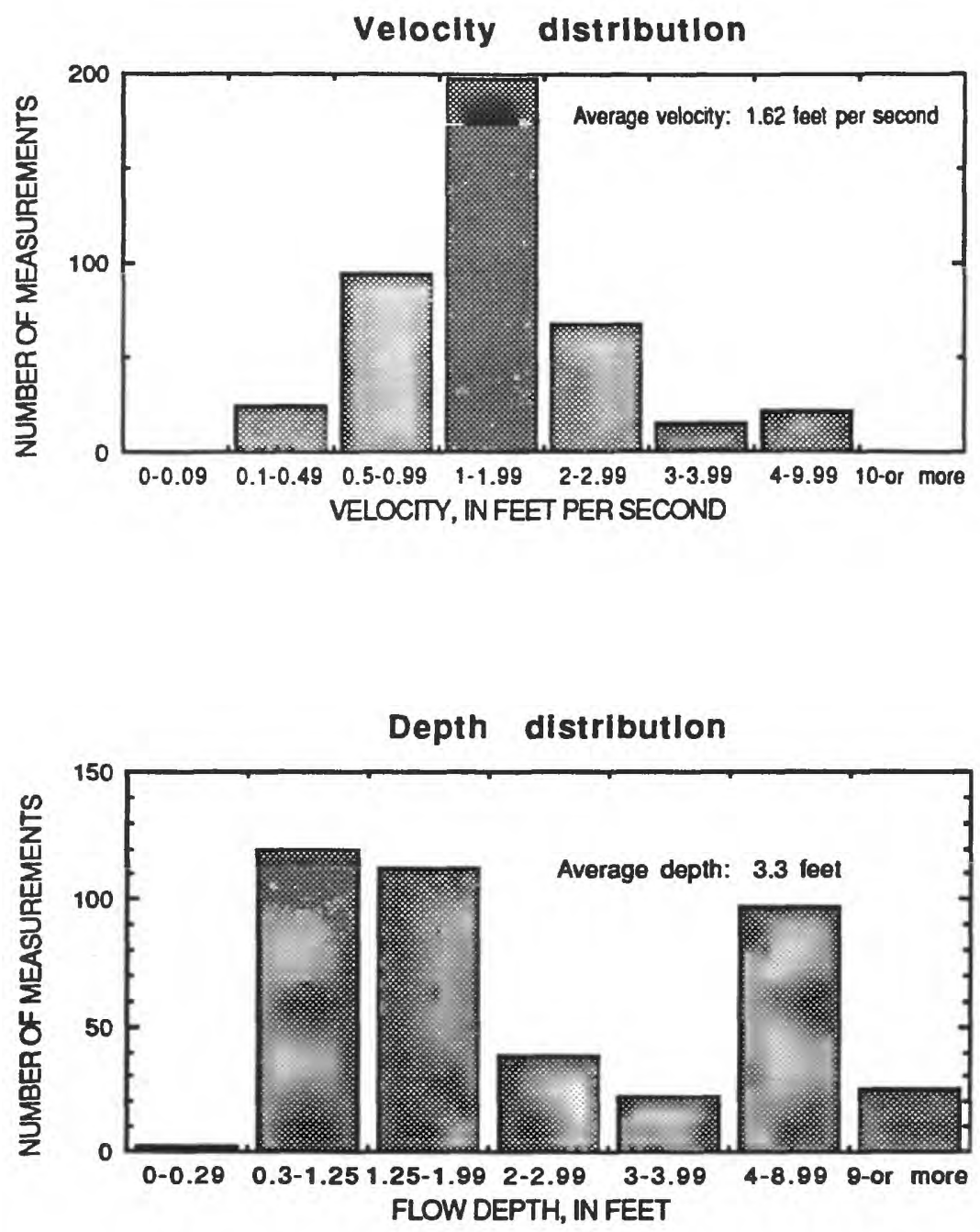

Measurement ratings, In percent

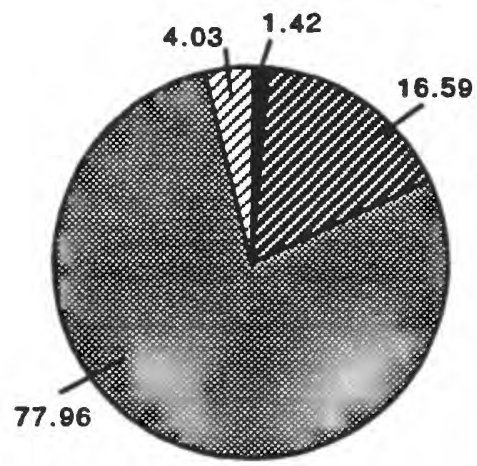

Measurement types, in percent

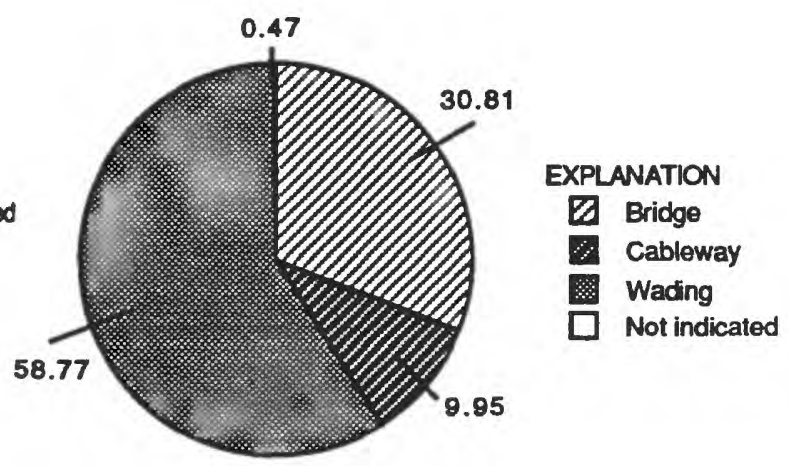

Figure 56.--West Virginia's velocity and depth frequency distributions and percentage of measurements by measurement rating and by measurement type for water year 1990 . 


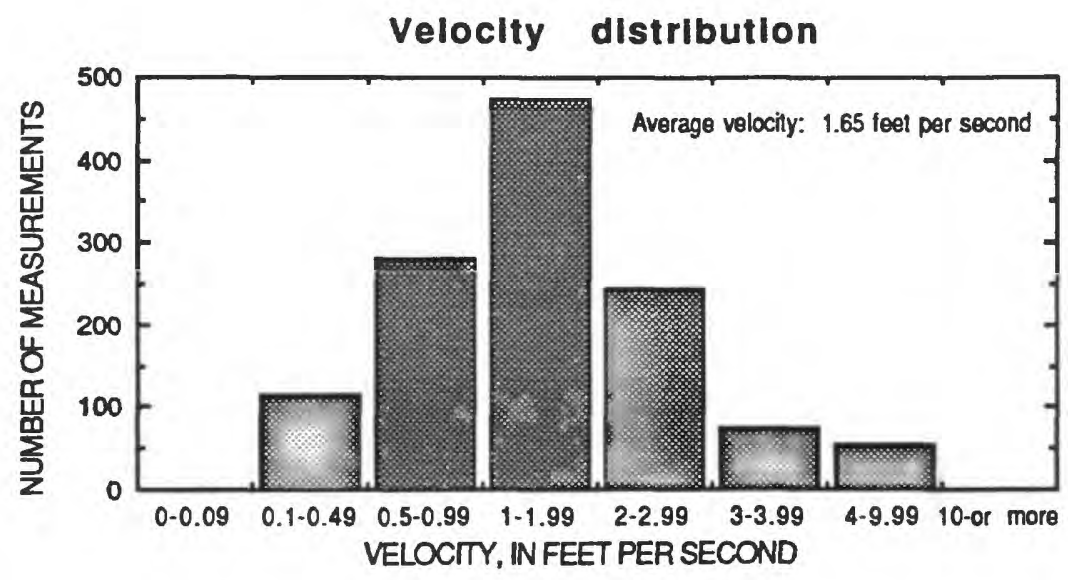

Depth distribution
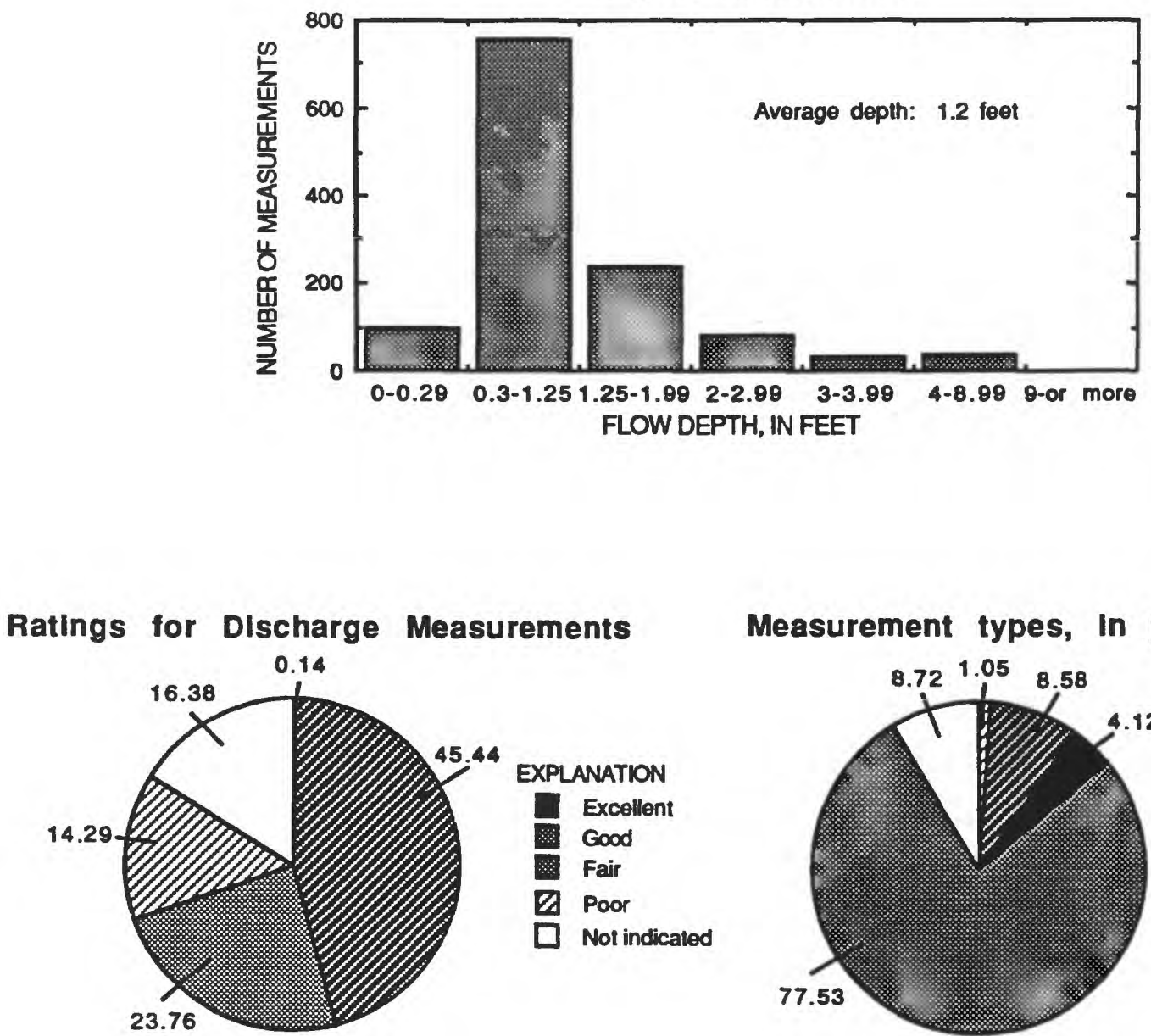

Measurement types, In percent

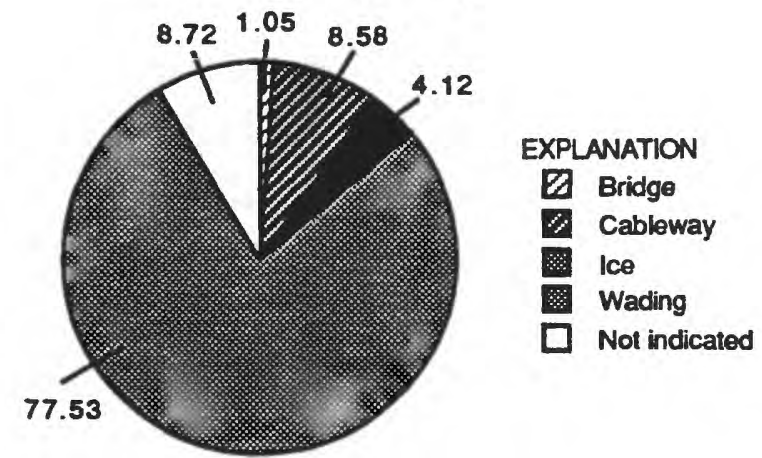

Figure 57.--Wyoming's velocity and depth frequency distributions and percentage of measurements by measurement rating and by measurement type for water year 1990 . 
Table 12.--Summary statistics for computed flow characteristics for measurements made in water year 1990

[ft, feet; Kn, conveyance times Manning's coefficient of roughness; $\mathrm{ft}^{3} / \mathrm{s}$, cubic feet per second]

\begin{tabular}{|c|c|c|c|c|c|}
\hline $\begin{array}{c}\text { Computed flow } \\
\text { characteristic }\end{array}$ & Mean & $\begin{array}{l}\text { Standard } \\
\text { deviation }\end{array}$ & Low & High & Count \\
\hline Wetted perimeter $(\mathrm{ft})$ & 110.2 & 237.2 & 0.1 & $13,701.2$ & 51,069 \\
\hline Shape & 57.4 & 537.7 & 0 & 110,653 & 51,066 \\
\hline Squared Froude number & 0.069 & 0.14 & 0 & 12.44 & 51,000 \\
\hline $\mathrm{Kn}\left(\mathrm{ft}^{3} / \mathrm{s}\right)$ & 5,177 & $40,322.9$ & 0 & $\begin{array}{l}2,034 \\
405.1\end{array}$ & 51,069 \\
\hline
\end{tabular}

\section{Computed Flow Characteristics}

Hydraulic computations and flow models use characteristics that are computed from velocity, depth, roughness, and area of flow. Some of these common flow characteristics are the Froude number, the wetted perimeter, a shape number, and conveyance times Manning's n. Summary statistics for each computed characteristic are determined for all the 1990 water year measurements and for each District's measurements.

The selected flow characteristics are computed from the data for each measurement. The shape number is computed as a dimensionless ratio of width to mean depth for a given measurement. The wetted perimeter is an estimate of the actual wetted perimeter. It is computed as the width plus 2 times the depth.

The Froude number is a dimensionless number that represents the ratio of inertial force to gravitational force. The squared Froude number was computed for each measurement as:

$$
F^{2}=\frac{v^{2}}{g D}
$$

where $v$ is the mean velocity, $g$ the acceleration of gravity, and $D$ is the mean depth of flow. Because open-channel flow is free surface flow, the Froude number is important to flow computations.

The conveyance times the Manning's coefficient ( $\mathrm{n}$ values) of roughness is computed as:

$$
\mathrm{Kn}=1.49 \mathrm{AR}^{2 / 3}
$$

where $\mathrm{A}$ is the cross-sectional area and $\mathrm{R}$ is the hydraulic radius. The quantity is a substitute for conveyance. The discharge measurement data lacks roughness values from which to compute conveyance directly.

Summary statistics for the computed flow characteristics for each state are listed in table 12 for all the measurements and in table 13 by state (or district). For most measurements the squared Froude number is less than one, signifying tranquil flow conditions. The average stream width is 50 times the depth. 
Table 13.--Summary statistics for computed flow characteristics listed by state for water year 1990

[S.D., standard deviation; No., number computed; ft, feet; Kn, conveyance times Manning's coefficient of roughness; $\mathrm{ft}^{3} / \mathrm{s}$, cubic per second]

\begin{tabular}{|c|c|c|c|c|c|c|c|c|}
\hline \multirow[t]{3}{*}{ STATE } & \multicolumn{2}{|c|}{$\begin{array}{c}\text { WETTED } \\
\text { PERIMETER } \\
\text { (ft) }\end{array}$} & \multicolumn{2}{|c|}{ SHAPE } & \multicolumn{2}{|c|}{$\begin{array}{c}\text { SQUARED } \\
\text { FROUDE } \\
\text { NUMBER }\end{array}$} & \multicolumn{2}{|c|}{$\mathrm{Kn}\left(\mathrm{ft}^{3 / \mathrm{s}}\right)$} \\
\hline & Mean & & Mean & & Mean & & Mean & \\
\hline & S.D. & No. & S.D. & No. & S.D. & No. & S.D. & No. \\
\hline \multirow[t]{2}{*}{ Alaska } & 193 & & 58 & & 0.118 & & 13,129 & \\
\hline & 356 & 477 & 62 & 477 & 0.133 & 474 & 52,205 & 477 \\
\hline \multirow[t]{2}{*}{ Alabama } & 112 & & 54 & & 0.044 & & 3,212 & \\
\hline & 247 & 692 & 128 & 692 & 0.047 & 692 & 12,885 & 692 \\
\hline \multirow[t]{2}{*}{ Arkansas } & 208 & & 56 & & 0.060 & & 32,252 & \\
\hline & 311 & 320 & 286 & 320 & 0.220 & 320 & 107,833 & 320 \\
\hline \multirow[t]{2}{*}{ Arizona } & 79 & & 49 & & 0.087 & & 3,747 & \\
\hline & 122 & 744 & 109 & 744 & 0.429 & 743 & 12,991 & 744 \\
\hline \multirow[t]{2}{*}{ California } & 58 & & 41 & & 0.083 & & 812 & \\
\hline & 90 & 3,364 & 125 & 3,364 & 0.178 & 3,362 & 3,756 & 3,364 \\
\hline \multirow[t]{2}{*}{ Colorado } & 51 & & 51 & & 0.130 & & 187 & \\
\hline & 56 & 2,869 & 51 & 2,869 & 0.156 & 2,869 & 545 & 2,869 \\
\hline \multirow[t]{2}{*}{ Connecticut } & 83 & & 39 & & 0.051 & & 1,695 & \\
\hline & 147 & 289 & 26 & 289 & 0.055 & 289 & 7,986 & 289 \\
\hline \multirow[t]{2}{*}{ Delaware } & 42 & & 31 & & 0.044 & & 393 & \\
\hline & 33 & 164 & 24 & 164 & 0.056 & 164 & 944 & 164 \\
\hline \multirow[t]{2}{*}{ Florida } & 107 & & 38 & & 0.020 & & 5,905 & \\
\hline & 468 & 1,361 & 87 & 1,361 & 0.038 & 1,357 & 43,955 & 1,361 \\
\hline \multirow[t]{2}{*}{ Georgia } & 170 & & 46 & & 0.037 & & 7,944 & \\
\hline & 283 & 1,122 & 49 & 1,122 & 0.045 & 1,122 & 25,976 & 1,122 \\
\hline \multirow[t]{2}{*}{ Hawaii } & 15 & & 13 & & 0.040 & & 29 & \\
\hline & 14 & 563 & 11 & 563 & 0.040 & 562 & 110 & 563 \\
\hline \multirow[t]{2}{*}{ lowa } & 252 & & 75 & & 0.045 & & 15,454 & \\
\hline & 340 & 1,656 & 208 & 1,656 & 0.047 & 1,654 & 36,431 & 1,654 \\
\hline \multirow[t]{2}{*}{ Idaho } & 119 & & 50 & & 0.092 & & 4,222 & \\
\hline & 152 & 1,721 & 72 & 1,721 & 0.088 & 1,719 & 20,244 & 1,721 \\
\hline \multirow[t]{2}{*}{ Illinois } & 113 & & 46 & & 0.050 & & 3,888 & \\
\hline & 218 & 1,485 & 130 & 1,485 & 0.069 & 1,482 & 15,045 & 1,485 \\
\hline \multirow[t]{2}{*}{ Indiana } & 101 & & 44 & & 0.046 & & 2,122 & \\
\hline & 129 & 1,361 & 33 & 1,361 & 0.046 & 1,359 & 8,274 & 1,361 \\
\hline
\end{tabular}


Table 13.--Summary statistics for computed flow characteristics listed by state for water year 1990

[continued; S.D., standard deviation; No., number computed; $f t$, feet; Kn, conveyance times Manning's coefficient of roughness; $f_{t}{ }^{3} / s$, cubic per second]

\begin{tabular}{|c|c|c|c|c|c|c|c|c|}
\hline \multirow[t]{3}{*}{ STATE } & \multicolumn{2}{|c|}{$\begin{array}{c}\text { WETTED } \\
\text { PERIMETER } \\
\text { (ft) }\end{array}$} & \multicolumn{2}{|c|}{ SHAPE } & \multicolumn{2}{|c|}{$\begin{array}{c}\text { SQUARED } \\
\text { FROUDE } \\
\text { NUMBER }\end{array}$} & \multicolumn{2}{|c|}{$\mathrm{Kn}\left(\mathrm{ft}^{3} / \mathrm{s}\right)$} \\
\hline & Mcan & & Mean & & Mean & & Mean & \\
\hline & S.D. & No. & S.D. & No. & S.D. & No. & S.D. & No. \\
\hline \multirow[t]{2}{*}{ Kansas } & 101 & & 70 & & 0.067 & & 1,689 & \\
\hline & 174 & 1,153 & 110 & 1,153 & 0.098 & 1,152 & 6,628 & 1,153 \\
\hline \multirow[t]{2}{*}{ Kentucky } & 107 & & 55 & & 0.062 & & 7,036 & \\
\hline & 138 & 888 & 129 & 888 & 0.161 & 888 & 69,996 & 888 \\
\hline \multirow[t]{2}{*}{ Louisiana } & 230 & & 33 & & 0.015 & & 58,408 & \\
\hline & 369 & 362 & 25 & 362 & 0.023 & 356 & 199,909 & 362 \\
\hline Massachusetts \& & 54 & & 34 & & 0.058 & & 531 & \\
\hline Rhode Island & 44 & 515 & 26 & 515 & 0.052 & 514 & 2,993 & 515 \\
\hline \multirow[t]{2}{*}{ Maryland } & 57 & & 51 & & 0.058 & & 398 & \\
\hline & 77 & 591 & 243 & 591 & 0.073 & 591 & 2,119 & 591 \\
\hline \multirow[t]{2}{*}{ Maine } & 205 & & 84 & & 0.047 & & 4,451 & \\
\hline & 182 & 201 & 90 & 201 & 0.046 & 201 & 10,099 & 201 \\
\hline \multirow[t]{2}{*}{ Michigan } & 89 & & 50 & & 0.048 & & 1,113 & \\
\hline & 85 & 1,183 & 155 & 1,183 & 0.056 & 1,183 & 4,447 & 1,183 \\
\hline \multirow[t]{2}{*}{ Minnesota } & 75 & & 46 & & 0.089 & & 1,306 & \\
\hline & 85 & 545 & 35 & 544 & 0.740 & 544 & 6,232 & 545 \\
\hline \multirow[t]{2}{*}{ Missouri } & 398 & & 72 & & 0.054 & & 57,367 & \\
\hline & 630 & 1,771 & 281 & 1,171 & 0.063 & 1,169 & 166,570 & 1,171 \\
\hline \multirow[t]{2}{*}{ Mississippi } & 177 & & 51 & & 0.042 & & 8,653 & \\
\hline & 354 & 657 & 53 & 657 & 0.047 & 656 & 26,481 & 657 \\
\hline \multirow[t]{2}{*}{ Montana } & 95 & & 51 & & 0.093 & & 1,438 & \\
\hline & 117 & 1,709 & 131 & 1,709 & 0.096 & 1,709 & 5,079 & 1,709 \\
\hline \multirow[t]{2}{*}{ North Carolina } & 65 & & 36 & & 0.044 & & 753 & \\
\hline & 64 & 1,045 & 38 & 1,045 & 0.058 & 1,045 & 2,267 & 1,045 \\
\hline \multirow[t]{2}{*}{ North Dakota } & 54 & & 102 & & 0.073 & & 810 & \\
\hline & 119 & 599 & 1,225 & 606 & 0.147 & 596 & 3,836 & 599 \\
\hline \multirow[t]{2}{*}{ Nebraska } & 137 & & 194 & & 0.093 & & 739 & \\
\hline & 315 & 1,587 & 2,801 & 1,587 & 0.085 & 1,585 & 3,387 & 1,587 \\
\hline \multirow[t]{2}{*}{ New Jersey } & 69 & & 37 & & 0.040 & & 895 & \\
\hline & 110 & 627 & 28 & 627 & 0.047 & 627 & 3,603 & 627 \\
\hline
\end{tabular}


Table 13.--Summary statistics for computed flow characteristics listed by state for water year 1990

Icontinued; S.D., standard deviation; No., number computed; $f t$, feet; $K n$, conveyance times Manning's coefficient of roughness; $\mathrm{ft}^{3} / \mathrm{s}$, cubic per second]

\begin{tabular}{|c|c|c|c|c|c|c|c|c|}
\hline \multirow[t]{3}{*}{ STATE } & \multicolumn{2}{|c|}{$\begin{array}{c}\text { WETTED } \\
\text { PERIMETER } \\
(f t)\end{array}$} & \multicolumn{2}{|c|}{ SHAPE } & \multicolumn{2}{|c|}{$\begin{array}{l}\text { SQUARED } \\
\text { FROUDE } \\
\text { NUMBER }\end{array}$} & \multicolumn{2}{|c|}{$\mathrm{Kn}\left(\mathrm{ft}^{3} / \mathrm{s}\right)$} \\
\hline & Mean & & Mean & & Mean & & Mean & \\
\hline & S.D. & No. & S.D. & No. & S.D. & No. & S.D. & No. \\
\hline \multirow[t]{2}{*}{ New Mexico } & 53 & & 50 & & 0.092 & & 177 & \\
\hline & 59 & 1,302 & 114 & 1,302 & 0.089 & 1,301 & 376 & 1,302 \\
\hline \multirow[t]{2}{*}{ Nevada } & 30 & & 29 & & 0.092 & & 95 & \\
\hline & 33 & 958 & 26 & 957 & 0.138 & 955 & 243 & 958 \\
\hline \multirow[t]{2}{*}{ New York } & 103 & & 61 & & 0.060 & & 1,226 & \\
\hline & 120 & 1,486 & 58 & 1,486 & 0.060 & 1,486 & 5,906 & 1,486 \\
\hline \multirow[t]{2}{*}{ Ohio } & 116 & & 67 & & 0.065 & & 1,989 & \\
\hline & 112 & 819 & 154 & 819 & 0.079 & 819 & 5,963 & 819 \\
\hline \multirow[t]{2}{*}{ Oklahoma } & 168 & & 86 & & 0.061 & & 7,831 & \\
\hline & 331 & 981 & 209 & 981 & 0.073 & 967 & 27,761 & 981 \\
\hline \multirow[t]{2}{*}{ Oregon } & 105 & & 48 & & 0.067 & & 2,642 & \\
\hline & 106 & 884 & 116 & 884 & 0.080 & 884 & 21,292 & 884 \\
\hline \multirow[t]{2}{*}{ Pennsylvania } & 140 & & 86 & & 0.056 & & 3,224 & \\
\hline & 213 & 1,890 & 598 & 1,890 & 0.128 & 1,889 & 18,206 & 1,890 \\
\hline \multirow[t]{2}{*}{ Puerto Rico } & 39 & & 59 & & 0.047 & & 73 & \\
\hline & 29 & 703 & 65 & 703 & 0.057 & 703 & 240 & 703 \\
\hline \multirow[t]{2}{*}{ South Carolina } & 157 & & 57 & & 0.037 & & 6,551 & \\
\hline & 417 & 608 & 236 & 608 & 0.064 & 608 & 26,974 & 608 \\
\hline \multirow[t]{2}{*}{ South Dakota } & 41 & & 43 & & 0.070 & & 848 & \\
\hline & 92 & 1,159 & 84 & 1,159 & 0.121 & 1,157 & 7,840 & 1,159 \\
\hline \multirow[t]{2}{*}{ Tennessee } & 126 & & 52 & & 0.075 & & 5,438 & \\
\hline & 206 & 637 & 50 & 637 & 0.234 & 637 & 27,298 & 637 \\
\hline \multirow[t]{2}{*}{ Texas } & 151 & & 60 & & 0.065 & & 7,417 & \\
\hline & 432 & 2,099 & 178 & 2,098 & 0.089 & 2,094 & 29,861 & 2,099 \\
\hline \multirow[t]{2}{*}{ Utah } & 46 & & 38 & & 0.089 & & 233 & \\
\hline & 59 & 1,555 & 30 & 1,555 & 0.102 & 1,555 & 807 & 1,555 \\
\hline \multirow[t]{2}{*}{ Virginia } & 150 & & 67 & & 0.042 & & 2,605 & \\
\hline & 152 & 608 & 170 & 608 & 0.053 & 608 & 5,527 & 608 \\
\hline Vermont \& & 95 & & 48 & & 0.061 & & 1,767 & \\
\hline New Hampshire & 86 & 372 & 39 & 372 & 0.071 & 372 & 6,009 & 372 \\
\hline
\end{tabular}


Table 13.--Summary statistics for computed flow characteristics listed by state for water year 1990

[continued; S.D., standard deviation; No., number computed; ft, feet; Kn, conveyance times Manning's coefficient of roughness; $\mathrm{ft}^{3} / \mathrm{s}$, cubic per second]

\begin{tabular}{|c|c|c|c|c|c|c|c|c|}
\hline \multirow[t]{3}{*}{ STATE } & \multicolumn{2}{|c|}{$\begin{array}{l}\text { WETTED } \\
\text { PERIMETER } \\
\text { (ft) }\end{array}$} & & PE & \multirow{2}{*}{\multicolumn{2}{|c|}{$\begin{array}{l}\text { SQUARED } \\
\text { FROUDE } \\
\text { NUMBER } \\
\text { Mean }\end{array}$}} & \multicolumn{2}{|c|}{$K n\left(f t^{3} / s\right)$} \\
\hline & Mean & & Mean & & & & Mean & \\
\hline & S.D. & No. & S.D. & No. & S.D. & No. & S.D. & No. \\
\hline Washington & $\begin{array}{l}115 . \\
167 .\end{array}$ & 1,463 & $\begin{array}{r}44 . \\
117 .\end{array}$ & 1,463 & $\begin{array}{l}0.099 \\
0.110\end{array}$ & 1,457 & $\begin{array}{l}11,883 . \\
76,352 .\end{array}$ & 1,463 \\
\hline Wisconsin & $\begin{array}{l}115 . \\
151 .\end{array}$ & 876 & $\begin{array}{l}54 . \\
46 .\end{array}$ & 876 & $\begin{array}{l}0.049 \\
0.051\end{array}$ & 876 & $\begin{array}{l}2,334 . \\
7,915 \text {. }\end{array}$ & 876 \\
\hline West Virginia & $\begin{array}{l}162 . \\
169 .\end{array}$ & 418 & $\begin{array}{l}60 . \\
41 .\end{array}$ & 418 & $\begin{array}{l}0.044 \\
0.045\end{array}$ & 418 & $\begin{array}{r}6,667 . \\
29,927 .\end{array}$ & 418 \\
\hline Wyoming & $\begin{array}{l}68 . \\
75 .\end{array}$ & 1,239 & $\begin{array}{l}54 . \\
50 .\end{array}$ & 1,239 & $\begin{array}{l}0.101 \\
0.111\end{array}$ & 1,239 & $\begin{array}{l}314 . \\
850 .\end{array}$ & 1,239 \\
\hline
\end{tabular}

\section{COMPARISON OF QUESTIONNAIRE RESULTS WITH COMPUTER DATA BASE}

The two parts of the survey have some duplication. Both surveys have information on the number of continuous-record sites, number of measurements per site, and rating of particular measurement types. Data for rating of particular measurement types were not analyzed by the same technique and cannot be compared easily. Numbers for the two surveys that can be compared easily are in reasonable agreement.

The computer data base has 194 more continuous-record sites for 1990 than does the questionnaire. Because two states did not return a questionnaire, this difference is reasonable and not unexpected. Analysis of the questionnaire yielded half a measurement more per continuousrecord site than did the computer data-base data. This difference is small.

\section{SUMMARY}

The U.S. Geological Survey uses current meters to make tens of thousands of discharge measurements each year. Because of interest in the performance and evaluation of current meters, a comprehensive survey of discharge measurement data and meter usage for water year 1990 was conducted. The survey has two parts: data from questionnaires on current meter usage that were sent to Districts offices and data on discharge-measurements that were retrieved from District computer data bases. Analysis of data from the survey provides summary statistics and information on meter usage, measurement conditions, and discharge data.

Using the mean values from the computer data-base retrievals, the average value of all measured discharges is $1,960 \mathrm{ft}^{3} / \mathrm{s}$ with a mean velocity of $1.52 \mathrm{ft} / \mathrm{s}$. Three-fourths of the discharge measurements are made by wading and most measurements are rated good (error in discharge measurement is more than 2 and less than 5 percent). Most discharge measurements are made in tranquil flow conditions (Froude number $<1$ ). The Price type-AA meter is used for more than half the measurements. The pygmy meter is used for most of the remaining measurements. Questionnaire respondents indicated the presence of vegetation as the most frequent cause of fair or 
than 8 percent; for poor ratings error is equal to or more than 8 percent). Irregular cross sections, low velocities, rapid stage changes, and shallow depths were also ranked high by respondents as causes of fair or poor measurement ratings.

This information quantifies the conditions in which USGS current meters must operate successfully and the problems encountered when using them. This data may also be of interest to open-channel flow modelers and other hydrologists because it quantifies the range of several common flow parameters for streams throughout the United States. 


\section{REFERENCES CITED}

Herschy, R.W., 1985, Streamflow measurement: New York, N.Y., Elsevier Applied Science Publishers LTD., 553 p.

Rantz, S.E.,1982, Measurement and computation of streamflow: volume 1. measurement of stage and discharge, U.S. Geological Survey Water Supply Paper 2175, p. 79-183. 